\title{
Panduan Cara Pemberian Skor dan Analisis untuk Menilai Kesejahteraan Manusia
}

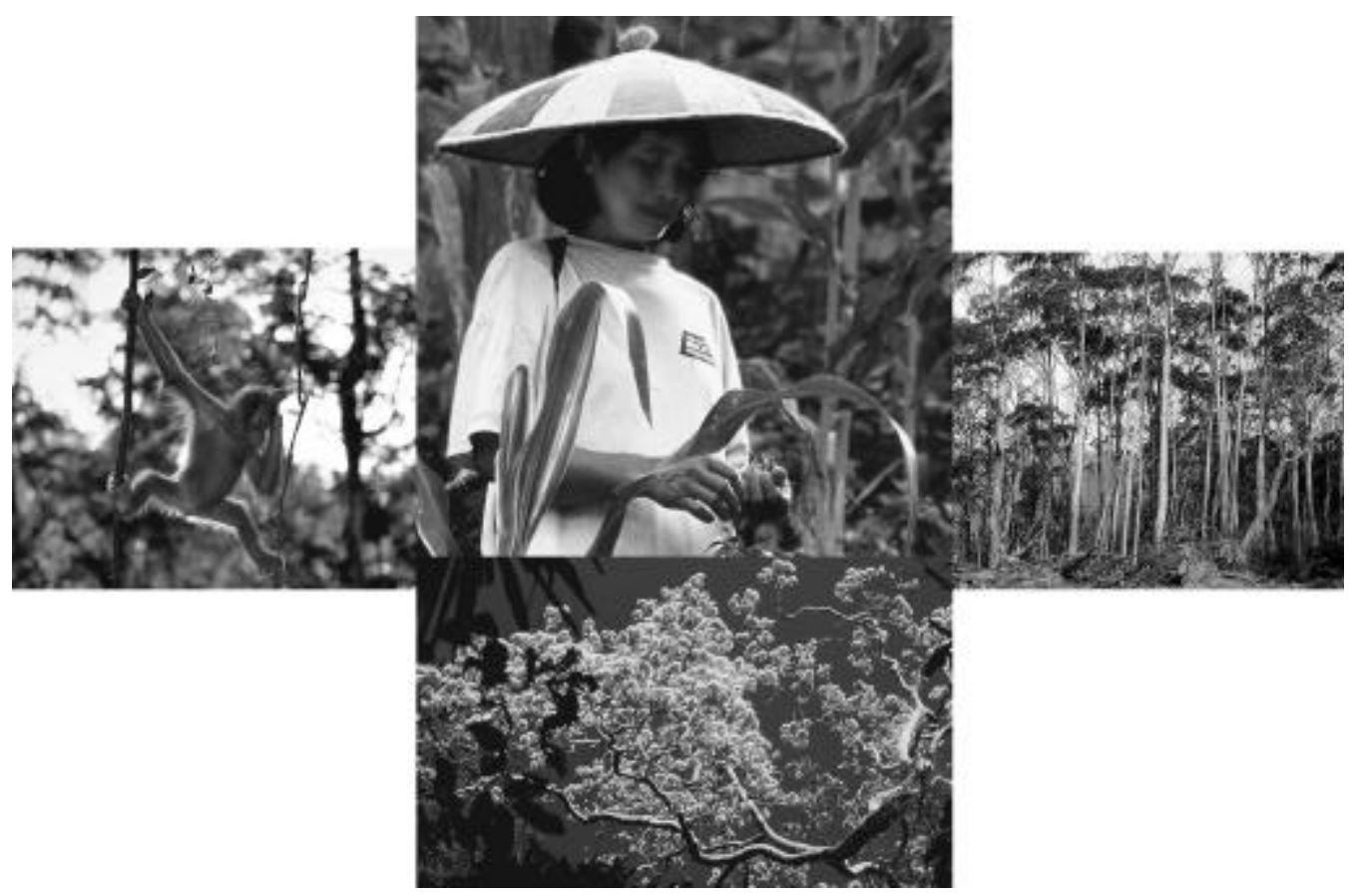

Perangkat Kriteria dan Indikator 


\section{Panduan Cara Pemberian Skor dan Analisis untuk Menilai Kesejahteraan Manusia}

Agus Salim dan Carol J. Pierce Colfer dengan Cynthia McDougall

Alih bahasa

Ani Kartikasari dan Meiske D. Tapilatu

Perangkat Kriteria dan Indikator 
(C) 1999 oleh Center for International Forestry Research

Dicetak oleh SMK Grafika Mardi Yuana, Bogor

Fotografi

Orang utan remaja oleh Anonymous

Tegakan Eucalyptus paliformis oleh John Turnbull

Seorang wanita di ladangnya, Tanah Merah, Indonesia oleh Alain Compost

Pohon yang sedang berbunga di hutan tropis, Peru oleh Andre Bartschi (WWF)

Para penulis ingin menyatakan penghargaan kepada Herlina Hartanto, Herry Purnomo, Daju Pradnja Resosudarmo, Rahayu Koesnadi, Agus Salim, Abdurrahman Syebubakar, Meilinda Wan dan Yurdi Yasmi yang melakukan pengecekan kualitas terjemahan seri perangkat ini, dan juga kepada Meiske D. Tapilatu dan Dwiati Novita Rini yang melakukan pengecekan selama proses persiapan pencetakan.

ISBN: 979-8764-39-0

Diterbitkan oleh

Center for International Forestry Research (CIFOR)

Alamat: PO Box 6596 JKPWB, Jakarta 10065, Indonesia

Telepon: +62-251-622 622 Fax: +62-251-622 100

E-mail: cifor@cgiar.org

WWW: http://www.cgiar.org/cifor

Dengan dukungan dana dari

The European Commission

Anggaran B7-6021 yang berkaitan dengan 'Hutan Tropis'

Brusel, Belgia

Deutsche Gesellschaft für Technische Zusammenarbeit (GTZ) GmbH

Eschborn, Jerman

United States Agency for International Development (USAID)

Washington D.C., Amerika Serikat

Pencetakan edisi bahasa Indonesia ini sebagian besa didanai oleh kantor Ford Foundation di Indonesia. 


\section{Seri Perangkat K\&I}

\begin{tabular}{|c|c|}
\hline Perangkat K\&I No. 1 & $\begin{array}{l}\text { Panduan untuk Pengembangan, Pengujian dan Pemilihan } \\
\text { Kriteria dan Indikator untuk Pengelolaan Hutan Lestari } \\
\text { Prabhu, R., Colfer, C.J.P. dan Dudley, R.G. }\end{array}$ \\
\hline Perangkat K\&I No. 2 & $\begin{array}{l}\text { Acuan Generik Kriteria dan Indikator CIFOR } \\
\text { Tim KEI CIFOR }\end{array}$ \\
\hline Perangkat K\&I No. 3 & $\begin{array}{l}\text { Perangkat Modifikasi dan Adaptasi Kriteria dan Indikator } \\
\text { (CD-ROM) } \\
\text { Prabhu, R., Haggith, M., Purnomo, H., Rizal, A., Sukadri, } \\
\text { D., Taylor, J. dan Yasmi, Y. }\end{array}$ \\
\hline Perangkat K\&I No. 4 & $\begin{array}{l}\text { Sistem Basis Data Kriteria dan Indikator CIFOR } \\
\text { McDougall, C., Isbadi, I.R., Santoso, L., Corless, M. dan } \\
\text { Purnomo, H. (ed.) }\end{array}$ \\
\hline Perangkat K\&I No. 5 & $\begin{array}{l}\text { Panduan Penilaian Dasar Kesejahteraan Manusia } \\
\text { Colfer, C.J.P., Brocklesby, M.A., Diaw, C., Etuge, P., Günter, } \\
\text { M., Harwell, E., McDougall, C., Porro, N.M., Porro, R., } \\
\text { Prabhu, R., Salim, A., Sardjono, M.A., Tchikangwa, B., Tiani, } \\
\text { A.M., Wadley, R.L., Woelfel, J. dan Wollenberg, E. }\end{array}$ \\
\hline Perangkat K\&I No. 6 & $\begin{array}{l}\text { Panduan Pendamping Penilaian Dasar Kesejahteraan } \\
\text { Manusia } \\
\text { Colfer, C.J.P., Brocklesby, M.A., Diaw, C., Etuge, P., Günter, } \\
\text { M., Harwell, E., McDougall, C., Porro, N.M., Porro, R., } \\
\text { Prabhu, R., Salim, A., Sardjono, M.A., Tchikangwa, B., Tiani, } \\
\text { A.M., Wadley, R.L., Woelfel, J. dan Wollenberg, E. }\end{array}$ \\
\hline Perangkat K\&I No. 7 & $\begin{array}{l}\text { Panduan Cara Pemberian Skor dan Analisis untuk Menilai } \\
\text { Kesejahteraan Manusia } \\
\text { Salim, A. dan Colfer, C.J.P., dengan McDougall, C. }\end{array}$ \\
\hline Perangkat K\&I No. 8 & $\begin{array}{l}\text { Siapa yang Perlu Dipertimbangkan? Menilai Kesejahteraan } \\
\text { Manusia dalam Pengelolaan Hutan Lestari } \\
\text { Colfer, C.J.P., Prabhu, R., Günter, M., McDougall, C., Porro, } \\
\text { N.M. dan Porro, R. }\end{array}$ \\
\hline Perangkat K\&I No. 9 & $\begin{array}{l}\text { Panduan untuk Menerapkan Analisis Multikriteria dalam } \\
\text { Menilai Kriteria dan Indikator } \\
\text { Mendoza, G.A., dan Macoun, P. dengan Prabhu, R., Sukadri, } \\
\text { D., Purnomo, dan Hartanto, H. }\end{array}$ \\
\hline
\end{tabular}

Perangkat K\&I No. 10 Metodologi untuk Menilai Indikator Ekologis dalam Pengelolaan Hutan Lestari (Dalam Persiapan) 


\section{DAFTAR ISI}

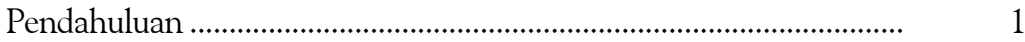

I. Panduan Cara Pemberian Skor ......................................................... 11

II. Lembar Isian Induk K\&I .................................................................

III. Panduan Analisis Kuantitatif ........................................................... 67
A. Analisis hasil dari metode identifikasi stakeholder (CatPac)
B. Analisis metode-metode untuk keamanan akses antargenerasi terhadap sumber daya
C. Analisis metode-metode untuk hak dan kemampuan mengelola hutan

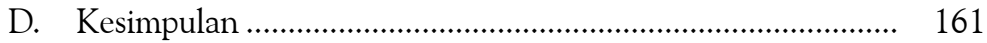
E. Daftar Pustaka …................................................................ 163
Lampiran A: Memeriksa perkiraan analisis regresi ........................ 165

\section{Daftar Gambar}

Gambar 1. Layar komputer menunjukkan bagian lembar isian induk K\&I

CatPac

Gambar 2. Peta kognitif untuk wanita Baka (Kawasan Lindung Dja, Kamerun) 


\section{Matriks Sejarah-Ekologi}

Gambar 3. Format lembar isian data sejarah-ekologi ..................... 76

Gambar 4. Memilih submenu Add-Ins (data sejarah-ekologi) ....... 77

Gambar 5. Memilih program khusus Add-Ins (data sejarah-ekologi) ................................................. 78

Gambar 6. Memulai analisis regresi untuk data sejarah-ekologi .... 79

Gambar 7. Penentuan kisaran variabel dalam cells (data sejarah-ekologi) ................................................. 80

Gambar 8. Hasil analisis regresi untuk data sejarah-ekologi .......... 81

Akses suatu generasi terhadap sumber daya

Gambar 9. Format lembar isian untuk data antargenerasi ............. 83

Gambar 10. Tombol label (data antargenerasi) ................................. 85

Gambar 11. Menentukan label untuk jender pada

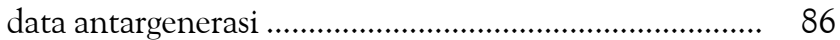

Gambar 12. Memilih tipe diagram kotak garis untuk data antargenerasi

Gambar 13. Memilih variabel-variabel data antargenerasi (untuk memeriksa distribusi data) ......................................... 88

Gambar 14. Diagram kotak garis untuk data antargenerasi ............ 89

Gambar 15. Memilih variabel antargenerasi ...................................... 90

Gambar 16. Tabel SPSS menggambarkan akses antargenerasi terhadap sumber daya menurut semua responden ........ 91

Gambar 17. Pola dasar tabel pivot (data antargenerasi) .................... 92

Gambar 18. Menyusun tabel pivot untuk analisis sederhana data antargenerasi (Tahap 1) ............................................. 93

Gambar 19. Menyusun tabel pivot untuk analisis sederhana data antargenerasi (Tahap 2) ............................................. 94

Gambar 20. Mengubah data statistik yang sudah diset pada data antargenerasi 
Gambar 21. Tabel MS Excel menggambarkan distribusi akses antargenerasi terhadap sumber daya menurut semua responden

Gambar 22. Memilih variabel antargenerasi (telah diringkas) ......... 97

Gambar 23. Memilih variabel demografi data antargenerasi ............ 98

Gambar 24. Tabel SPSS menggambarkan perbandingan distribusi akses antargenerasi terhadap sumber daya berdasarkan etnis

Gambar 25. Memilih tipe pengujian statistik untuk menguji kesepakatan data antargenerasi

Gambar 26. Memilih test variable dan grouping variable (data antargenerasi)

Gambar 27. Menentukan kisaran untuk grouping (demografi) variable (data antargenerasi)

Gambar 28. Hasil pengujian statistik untuk masing-masing generasi (data antargenerasi)

Gambar 29. Menyusun tabel pivot untuk analisis lanjutan data antargenerasi.

Gambar 30. Tabel MS Excel menggambarkan perbandingan distribusi akses antargenerasi terhadap sumber daya berdasarkan etnis

Pembagian manfaat di antara stakeholder

Gambar 31. Format lembar isian untuk data manfaat hutan ........... 107

Gambar 32. Tombol label (data manfaat hutan) ................................ 109

Gambar33. Menentukan label untuk data tingkat pendidikan pada data manfaat hutan

Gambar 34. Memilih tipe diagram kotak garis untuk data manfaat hutan

Gambar 35. Memilih variabel-variabel data manfaat hutan (untuk memeriksa distribusi data) 
Gambar 36. Diagram kotak garis untuk data manfaat hutan

Gambar 37. Memilih variabel-variabel data manfaat hutan untuk diringkas (Tahap 1)

Gambar 38. Memilih variabel-variabel data manfaat hutan untuk diringkas (Tahap 2)

Gambar 39. Tabel SPSS menggambarkan distribusi manfaat hutan menurut semua responden ............................................ 115

Gambar 40. Pola dasar tabel pivot (data manfaat hutan)

Gambar 41. Menyusun tabel pivot untuk analisis sederhana data manfaat hutan (Tahap 1)

Gambar 42. Menyusun tabel pivot untuk analisis sederhana data manfaat hutan (Tahap 2)

Gambar 43. Mengubah data statistik yang sudah diset pada data manfaat hutan

Gambar 44. Tabel MS Excel menggambarkan distribusi manfaat hutan menurut semua responden

Gambar 45. Memilih kasus untuk subkelompok yang khusus pada data manfaat hutan

Gambar 46. Menyaring responden dengan tingkat pendidikan yang lebih rendah pada data manfaat hutan

Gambar 47. Hasil seleksi (data manfaat hutan)

Gambar 48. Distribusi manfaat hutan di antara stakeholder menurut responden dengan tingkat pendidikan lebih rendah

Gambar 49. Perbandingan distribusi manfaat hutan di antara stakeholder berdasarkan tingkat pendidikan

Gambar 50. Menyaring data untuk Kenyah dan memilih pengujian statistik (data manfaat hutan)

Gambar 51. Memilih test variable dan grouping variable (data manfaat hutan) 
Gambar 52. Menentukan kisaran untuk grouping variable (data manfaat hutan) ............................................... 128

Gambar 53. Hasil pengujian statistik untuk Kenyah berdasarkan tingkat pendidikan (data manfaat hutan)

Gambar 54. Menyusun tabel pivot untuk analisis lanjutan data manfaat hutan

Gambar 55. Tabel MS Excel menggambarkan perbandingan

distribusi manfaat hutan berdasarkan tingkat pendidikan

Hak mengelola di antara stakeholder

Gambar 56. Format lembar isian untuk data hak mengelola 134

Gambar 57. Tombol label (data hak mengelola)

Gambar 58. Menentukan label untuk data tingkat pendidikan (data hak mengelola)

Gambar 59. Memilih tipe diagram kotak garis untuk data hak mengelola.

Gambar 60. Memilih variabel-variabel data hak mengelola (untuk memeriksa distribusi data).

Gambar 61. Diagram kotak garis untuk data hak mengelola 140

Gambar 62. Memilih variabel-variabel data hak mengelola untuk diringkas (Tahap 1)

Gambar 63. Memilih variabel-variabel data hak mengelola untuk diringkas (Tahap 2)

Gambar 64. Tabel SPSS menggambarkan distribusi hak mengelola di antara stakeholder menurut semua responden......... 143

Gambar 65. Pola dasar tabel pivot (data hak mengelola)................... 144

Gambar 66. Menyusun tabel pivot untuk analisis sederhana data hak mengelola (Tahap 1).

Gambar 67. Menyusun tabel pivot untuk analisis sederhana data hak mengelola (Tahap 2) 
Gambar 68. Mengubah data statistik yang sudah diset pada data hak mengelola

Gambar 69. Tabel MS Excel menggambarkan distribusi hak mengelola di antara stakeholder, menurut semua responden

Gambar 70. Memilih kasus untuk subkelompok yang khusus (data hak mengelola)

Gambar 71. Menyaring responden dengan tingkat pendidikan yang lebih rendah pada data hak mengelola 150

Gambar 72. Hasil seleksi kasus (data hak mengelola) 151

Gambar 73. Distribusi hak mengelola di antara stakeholder menurut responden dengan tingkat pendidikan lebih rendah

Gambar 74. Perbandingan distribusi hak mengelola di antara stakeholder berdasarkan tingkat pendidikan

Gambar 75. Menyaring data untuk Punan (data hak mengelola)

Gambar 76. Memilih tipe pengujian statistik untuk menguji kesepakatan data hak mengelola

Gambar 77. Memilih test variable dan grouping variable (data hak mengelola)

Gambar 78. Menentukan kisaran untuk grouping variable (data hak mengelola)

Gambar 79. Hasil pengujian statistik untuk Punan berdasarkan tingkat pendidikan (data hak mengelola)

Gambar 80. Menyusun tabel pivot untuk analisis lanjutan data hak mengelola

Gambar 81. Tabel MS Excel menggambarkan perbandingan distribusi hak mengelola berdasarkan tingkat pendidikan 
Memeriksa perkiraan analisis regresi

Gambar 82. Beberapa pola variansi residual ................................... 166

Gambar 83. Normal probability dari residual ..................................... 167

Gambar 84. Plot menunjukkan residual yang saling berkorelasi ....... 168

Daftar Tabel

'Tabel 1. Daftar sampel kasus dengan pemberian skor, dari Suaka Margasatwa Danau Sentarum, 1996 ................................... 48

Tabel 2. Pemberian skor K\&I untuk keamanan akses antargenerasi terhadap sumber daya ....................................... 63 


\section{PENDAHULUAN}

Kemampuan menilai kesejahteraan manusia dewasa ini semakin diakui sebagai suatu elemen penting dalam menilai pengelolaan hutan lestari di seluruh dunia. Sepuluh Perangkat K\&I CIFOR merupakan suatu set generik yang berisi Prinsip, Kriteria dan Indikator, dan metode-metode penilaian yang relevan. Perangkat-perangkat ini dirancang untuk membantu masyarakat dalam melakukan penilaian pengelolaan, khususnya di hutan produksi, di mana masyarakat tinggal dan bekerja di dalam dan di sekitar hutan tersebut. Penilaian ini meliputi aspek-aspek yang berkaitan dengan pengelolaan, lingkungan dan kesejahteraan manusia. Pihak-pihak potensial yang kemungkinan akan melakukan penilaian adalah para manajer proyek, lembaga sertifikasi, para donor, lembaga-lembaga pemerintah, para peneliti, LSM, dan masyarakat.

Perangkat ini, Panduan Cara Pemberian Skor dan Analisis untuk Menilai Kesejahteraan Manusia, membantu para pengguna Acuan Generik KEII dan metode-metode yang diusulkan dalam Panduan Penilaian Dasar (PPD) dan Panduan Pendamping Penilaian Dasar (PPPD) untuk memberikan skor dalam menilai kesejahteraan manusia, khususnya masyarakat yang berada di dalam dan di sekitar hutan tertentu. Berbagai kriteria dan indikator kesejahteraan manusia dikelompokkan dalam tiga prinsip, masing-masing dengan bobot sebagai berikut: 
P. 1 Pengelolaan hutan menjaga atau meningkatkan akses antargenerasi terhadap sumber daya dan berbagai manfaat ekonomi secara adil (B 1 $=40 \%)$

P. 2 Stakeholder yang relevan memiliki hak dan kemampuan yang diakui untuk mengelola hutan secara bersama dan adil (B $2=$ $30 \%)$

P. 3 Kesehatan hutan, para pengelola hutan dan budayanya dapat diterima oleh semua stakeholder (B $3=30 \%$ )

Kesejahteraan manusia $=[$ P. 1 (skor) $x$ B 1] $+[$ P. 2 (skor) x B 2] $+[$ P. 3 (skor) x B 3].

Bagian 1 merupakan panduan untuk memberikan skor terhadap berbagai kriteria dan indikator yang digunakan dalam penilaian kesejahteraan manusia. Sistem pemberian skornya sederhana, 1 berarti kondisi yang paling tidak lestari dan 10 yang paling lestari. Contoh-contoh atau kasus-kasus yang mencerminkan kondisi yang tidak lestari (1-3), tingkat kelestarian sedang (4-6) dan tingkat kelestarian yang cukup baik (7-10) disajikan untuk membantu para penilai mengevaluasi kondisi-kondisi yang mereka hadapi.

Bagian II menjelaskan cara menyiapkan lembar isian K\&I, dan mengembangkan 'lembar isian induk' K\&I seperti yang diberikan dalam PPD dan PPPD. Para pengguna kemudian dipandu melalui serangkaian tahap, termasuk:

1. menilai kelestarian (sering secara kualitatif) contoh dan kasus-kasus yang disediakan;

2. memberikan skor untuk masing-masing kasus/contoh (berdasarkan indikator tertentu);

3. menetapkan skor rata-rata untuk semua kasus yang dijadikan bukti dan yang berkaitan dengan indikator dalam kriteria tertentu; 
4. mengalikan skor rata-rata dengan faktor bobot dalam K\&I sosial; dan

5. merata-ratakan nilai yang diperoleh dalam langkah di atas, yang ditentukan untuk setiap kriteria, untuk memberikan nilai bagi prinsip, dan akhirnya untuk set K\&I sosial secara keseluruhan.

Prosedur tersebut merupakan cara untuk memudahkan pencatatan hasil pengamatan dan penilaian Anda secara sistematis. Prosedur ini membantu Anda untuk: mengingat apa yang telah Anda lihat; tetap terfokus pada K\&I yang sedang dinilai; dan mengidentifikasi kesenjangan dalam hal pengetahuan yang Anda miliki, sambil Anda melakukan proses penilaian. Nilai-nilai ini sekedar menggambarkan penilaian kualitatif Anda, berdasarkan pengamatan secara sistematis tentang kondisi-kondisi masyarakat di suatu lokasi. Nilai-nilai yang Anda hitung atau rata-ratakan bukan merupakan angka mati, tetapi merupakan nilai relatif.

Bagian III menyajikan panduan bagi mereka yang menggunakan metode kuantitatif yang diusulkan dalam PPD dan PPPD. Bagian ini akan memandu pengguna yang melakukan penilaian dengan menggunakan komputer dan program statistik, dan memudahkan pengembangan tabel-tabel deskriptif dan gambar-gambar yang sederhana untuk membantu pengguna melakukan penilaian. Fokus dalam panduan ini adalah analisis yang dihasilkan dari metode-metode berikut: Catpac, Matriks Sejarah-Ekologi, Akses suatu Generasi terhadap Sumber Daya, Pembagian Manfaat di antara para Stakeholder, dan Hak-hak Mengelola Hutan. Bagian ini manyajikan caracara mendasar bagi mereka yang belum berpengalaman menggunakan lembar isian, tetapi analisis yang lebih rumit juga bisa dilakukan jika minat, keahlian, dan waktu tersedia. 


\section{SET PRINSIP, KRITERIA DAN INDIKATOR CIFOR YANG DIUSULKANUNTUKMENILAI KESEJAHTERAANMANUSIA (BERDASARKAN HASIL PENGUJIAN LAPANGAN SELAMA LIMA TAHUN DI BERBAGAI TEMPAT DIDUNIA)}

\begin{tabular}{|c|c|}
\hline P. 1 & $\begin{array}{l}\text { PENGELOLAAN HUTAN MENJAGA ATAU MENINGKATKAN AKSES } \\
\text { ANTARGENERASI TERHADAP SUMBER DAYA DAN BERBAGAI } \\
\text { MANFAAT EKONOMI SECARA ADIL }\end{array}$ \\
\hline K. 1.1 & $\begin{array}{l}\text { Pihak pengelola lokal dapat secara efektif mengendalikan pemeliharaan dan } \\
\text { akses terhadap sumber daya }{ }^{1}\end{array}$ \\
\hline I. 1.1 .1 & $\begin{array}{l}\text { Kepemilikan dan hak pemanfaatan sumber daya (dalam satu generasi atau } \\
\text { antargenerasi) jelas dan mengakui klaim yang sudah ada }\end{array}$ \\
\hline I. 1.1 .2 & $\begin{array}{l}\text { Berbagai aturan dan norma dalam penggunaan sumber daya dipantau dan } \\
\text { ditegakkan pelaksanaannya }\end{array}$ \\
\hline I. 1.1 .3 & Cara-cara untuk mengatasi konflik berfungsi baik tanpa menggunakan kekerasan \\
\hline I. 1.1 .4 & Akses terhadap sumber daya dianggap adil oleh masyarakat lokal \\
\hline I. 1.1 .5 & Masyarakat lokal merasakan keamanan aksesnya terhadap sumber daya \\
\hline K. 1.2 & $\begin{array}{l}\text { Para pengelola hutan memperoleh manfaat ekonomi yang cukup dari hasil- } \\
\text { hasil hutan yang diambilnya }\end{array}$ \\
\hline I. 1.2 .1 & Mekanisme distribusi manfaat dianggap adil oleh masyarakat lokal \\
\hline I. 1.2 .2 & $\begin{array}{l}\text { Adanya kesempatan bagi masyarakat lokal dan masyarakat yang menggantungkan } \\
\text { hidupnya pada hutan untuk memperoleh pekerjaan dari perusahaan-perusahaan } \\
\text { kehutanan }\end{array}$ \\
\hline
\end{tabular}

1 Kriteria ini sangat erat kaitannya dengan kriteria yang ditinjau dari segi ekologi dan 'pengelolaan hutan' formal. 
I. 1.2.3 Upah dan tunjangan lainnya sesuai dengan standar nasional dan/atau ILO

I. 1.2.4 Ganti rugi terhadap kerusakan diberikan secara adil

I. 1.2.5 Berbagai hasil hutan digunakan secara optimal dan adil

K. 1.3 Masyarakat mengaitkan masa depan mereka dan anak-anak mereka dengan pengelolaan sumber daya hutan

I. 1.3.1 Masyarakat menanamkan modal di lingkungannya (misalnya, waktu, tenaga, uang)

I. 1.3.2 Tingkat migrasi keluar rendah ${ }^{2}$

I. 1.3.3 Masyarakat menyadari pentingnya keseimbangan antara jumlah penduduk dengan pemanfaatan sumber daya alam

I. 1.3.4 Anak-anak mendapatkan pendidikan (formal dan informal) tentang pengelolaan sumber daya alam

I. 1.3.5 Perusakan sumber daya alam oleh masyarakat lokal jarang terjadi

I. 1.3.6 Masyarakat memelihara hubungan batin dengan lahan hutan

2 Indikator 1.3.2 dan 3.1.2 berpotensi untuk kontradiktif. Tingkat migrasi keluar yang rendah (I. 1.3.2) mengindikasikan hubungan antara masa depan penduduk dan anak-anak mereka dengan pemeliharaan hutan; sementara itu pemahaman tentang perlunya keseimbangan antara jumlah penduduk dengan penggunaan sumber daya alam (I. 3.1.2) mungkin membuat mereka memilih untuk bermigrasi keluar. Biasanya kontradiksi ini kemungkinan besar terjadi ketika kondisi-kondisi memburuk. 


\section{P. 2 STAKEHOLDER YANG RELEVAN MEMILIKI HAK DAN KEMAM- PUAN YANG DIAKUI UNTUK MENGELOLA HUTAN SECARA BERSAMA DAN ADIL}

K. 2.1 Adanya berbagai mekanisme yang efektif untuk melakukan komunikasi dua arah antara para stakeholder dalam kaitannya dengan pengelolaan hutan

I. 2.1.1 > 50\% dari pegawai Departemen Kehutanan dan Perkebunan dan karyawan HPH dapat berbicara dalam satu atau beberapa bahasa lokal, atau $>50 \%$ wanita lokal dapat menggunakan bahasa yang digunakan oleh HPH dalam berinteraksi

I. 2.1.2 Para stakeholder lokal bertemu dengan frekuensi yang cukup, keragaman lokal cukup terwakili, dan dengan kualitas interaksi yang cukup

I. 2.1.3 Kontribusi masing-masing stakeholder saling dihormati dan dihargai secara wajar

K. 2.2 Para stakeholder memiliki pengetahuan yang lengkap tentang penggunaan sumber daya hutan (termasuk pengetahuan tentang kelompok-kelompok pengguna hutan dan peranan jender), dan juga pengetahuan tentang rencana pengelolaan hutan sebelum rencana tersebut dilaksanakan

I. 2.2.1 Adanya rencana/peta-peta yang menunjukkan pengintegrasian berbagai penggunaan hutan oleh berbagai stakeholder yang berbeda

I. 2.2.2 Rencana yang diperbarui, studi-studi dasar dan peta dapat diperoleh dengan mudah, yang menunjukkan rincian kawasan seperti penebangan hutan dan pembangunan jalan, disertai kerangka waktunya

I. 2.2.3 Studi-studi dasar tentang sistem masyarakat lokal juga tersedia dan diacu

I. 2.2.4 Pegawai pengelola hutan mengakui adanya berbagai kepentingan dan hak stakeholder lainnya

I. 2.2.5 Pengelolaan hasil hutan nonkayu (HHNK) mencerminkan kepentingan dan hakhak stakeholder lokal 
K. 2.3 Ada kesepakatan tentang hak-hak dan berbagai kewajiban stakeholder yang relevan

I. 2.3.1 Tingkat konflik yang ada dapat diterima oleh para stakeholder 


\section{P. 3 KESEHATAN HUTAN, PARA PENGELOLA HUTAN DAN BUDAYANYA DAPAT DITERIMA OLEH SEMUA STAKEHOLDER}

\section{K. 3.1 Ada keseimbangan yang cukup baik antara berbagai kegiatan manusia dan kondisi lingkungannya}

I. 3.1.1 Berbagai kondisi lingkungan yang dipengaruhi oleh kegiatan manusia tetap dalam keadaan stabil atau membaik

I. 3.1.2 Migrasi masuk dan/atau pertambahan penduduk secara alami selaras dengan pemeliharaan hutan

\section{K. 3.2 Ada pengakuan terhadap hubungan antara kesehatan masyarakat dengan pengelolaan hutan}

I. 3.2.1 Pihak pengelola hutan bekerjasama dengan pegawai kesehatan masyarakat dalam mengatasi berbagai penyakit yang berkaitan dengan pengelolaan hutan

I. 3.2.2 Status gizi masyarakat lokal cukup baik (misalnya, tingkat pertumbuhan tinggi dan berat badan anak-anak sesuai dengan standar internasional, tingkat kematian bayi dan balita rendah) ${ }^{3}$

I. 3.2.3 Para pegawai yang bekerja di bidang kehutanan memperhatikan persyaratanpersyaratan dan keamanan kerja sesuai dengan standar ILO dan bertanggung jawab atas risiko kesehatan yang berkaitan dengan pekerjaan mereka

\section{K. 3.3 Ada pengakuan terhadap pentingnya keterkaitan antara pemeliharaan hutan dengan kebudayaan}

3 Fakta bahwa indikator ini tidak selalu harus berhubungan langsung dengan kriterianya merupakan contoh salah satu kelemahan kriteria ketiga ini, yang disebabkan oleh kurangnya pengujian di lapangan yang dilakukan secara sistematis - dibandingkan dengan kedua kriteria lainnya. 
I. 3.3.1 Para pengelola hutan dapat menjelaskan keterkaitan antara budaya masyarakat dengan hutan lokal

I. 3.3.2 Rencana-rencana pengelolaan hutan mencerminkan perhatian terhadap isuisu yang terkait dengan kebudayaan

I. 3.3.3 Tidak ada tanda-tanda tentang adanya perpecahan budaya 


\section{T Panduan Cara Pemberian Skor}

Pada halaman-halaman berikut ini, kami mulai dengan berbagai prinsip, kriteria dan indikator dalam Acuan K\&I CIFOR yang terkait dengan isu-isu sosial. Kami berasumsi bahwa dalam menilai kelestarian isu-isu sosial sama pentingnya dengan isu-isu ekologi dan produksi. Dalam K\&I sosial, kami telah memberikan bobot (persentase) untuk masing-masing prinsip; dan kami membagi persentase tersebut untuk masing-masing prinsip dan kemudian membaginya lagi ke dalam bobot kriteria. Bobot ini diletakkan dalam tanda kurung setelah masing-masing prinsip (total) dan masing-masing kriteria (bagian dari bobot total untuk prinsip). Bobot ini diberikan berdasarkan perkiraan kualitatif tim kami di lapangan yang menguji kriteria dan indikator serta metode untuk menilai bobot ini di berbagai negara. Bobot ini mungkin perlu disesuaikan dengan keadaan lapangan yang berbeda. Kami menyarankan para pengguna untuk tidak memperlakukan skor dan bobot ini sebagai nilai mutlak. Meskipun skor dan bobot yang kami hasilkan mewakili perkiraan terbaik tentang bagaimana menilai isu-isu kelestarian pada saat ini, kami menyadari bahwa hasil ini masih belum sempurna. Kami mohon para pengguna memperhatikan hal ini.

Bagian berikut ini menjelaskan cara memberikan skor untuk kesimpulan kualitatif, dalam bagian (II) kami tunjukkan bagaimana membuat lembar isian induk K\&I - suatu alat untuk tetap melacak bahan-bahan dari kasus yang Anda gunakan, untuk membantu agar Anda melakukan penilaian terhadap masing-masing indikator, sampai Anda mencapai skor akhir dalam penilaian Anda. Kami juga menyajikan contoh-contoh atau berbagai kasus yang telah diberi skor. 


\section{P. 1 PENGELOLAAN HUTAN MENJAGA ATAU MENINGKATKAN AKSES ANTARGENERASI TERHADAP SUMBER DAYA DAN BERBAGAI MANFAAT EKONOMI SECARA ADIL (NILAI TOTAL $=\mathbf{4 0} \%$ )}

K. 1.1 Pihak pengelola lokal dapat secara efektif mengendalikan pemeliharaan dan akses terhadap sumber daya $^{4}($ Bobot $=15 \%)$

I. 1.1.1 Kepemilikan dan hak pemanfaatan sumber daya (dalam satu generasi atau antargenerasi) jelas dan mengakui klaim yang sudah ada

\section{SKOR 1-3}

Ada perbedaan pandangan tentang peraturan kepemilikan di antara stakeholder yang berbeda (misalnya, pemerintah dan perusahaan HPH menyatakan bahwa hutan adalah milik mereka, sementara penduduk menganggap bahwa hutan adalah milik mereka).

\section{SKOR 4-6}

Walaupun ada beberapa ketidaksepakatan spesifik di antara para stakeholder (jenis tertentu atau kawasan-kawasan yang agak khusus merupakan sumber konflik), berbagai stakeholder menerangkan kepemilikan dan hak-hak untuk memanfaatkan sumber daya hutan dengan cara yang sama. Mungkin ada perbedaan kepemilikan/hak-hak untuk menggunakan kawasan berdasarkan tempat, musim atau hasilnya.

\section{SKOR 7-10}

Tampaknya ada kesepakatan penuh, lebih disukai berstatus legal, tentang berbagai bentuk kepemilikan dan hak-hak pakai atas sumber daya lokal. Kepemilikan pribadi terhadap lahan dan/atau tumbuhan, kepemilikan bersama, dan berbagai sistem hak pakai adalah bentuk-bentuk pilihan kesepakatan yang ada.

4 Kriteria ini sangat erat kaitannya dengan kriteria yang ditinjau dari segi ekologi dan 'pengelolaan hutan' formal. Bobot 15 juga mencakup hal-hal lain dalam seluruh penilaian. 
I. 1.1.2 Berbagai aturan dan norma dalam penggunaan sumber daya dipantau dan ditegakkan pelaksanaannya

\section{SKOR 1-3}

Tidak ada aturan dan norma dalam penggunaan sumber daya atau tidak berfungsi. Banyak terlihat contoh penduduk yang tidak patuh kepada aturan-aturan lokal (misalnya, penduduk yang datang dari masyarakat lain dan mengumpulkan rotan dalam suatu kawasan padahal kegiatan ini memerlukan ijin; atau penduduk dari luar masyarakat lokal berburu dalam kawasan di mana penduduk lokal mempunyai hak eksklusif). Tidak terlihat adanya mekanisme yang efektif untuk memantau atau menegakkan peraturan-peraturan lokal.

\section{SKOR 4-6}

Ada berbagai aturan dan norma, tetapi mungkin bertentangan dengan aturan-aturan lain (misalnya, aturan-aturan masyarakat lokal vs. aturan-aturan pemerintah, atau bahkan kerancuan peraturan antara bagian konservasi vs. bagian pembalakan dari pihak Departeman Kehutanan). Para penilai mencatat kadang ada penduduk yang melanggar aturan lokal tetapi lebih banyak penduduk yang taat, dengan demikian sistem tersebut berjalan. Ada beberapa bukti bahwa ada mekanisme pemantauan, walaupun mekanisme peraturan tersebut tidak berjalan dengan sempurna. Sanksi-sanksi setidaknya diterapkan sekali-kali (misalnya, para pelanggar aturan ditangkap, dikenakan denda, dimasukkan ke dalam penjara, dll.).

\section{SKOR 7-10}

Berbagai aturan dan norma lokal ditetapkan secara jelas dan diterapkan secara konsisten. Para penilai hanya menemukan tidak lebih dari satu contoh pelanggaran terhadap aturan yang berlaku tanpa mendapat ganjaran, dan para stakeholder lokal merasa bahwa pengelolaan sumber daya terkendali. 
I. 1.1.3 Cara-cara untuk mengatasi konflik berfungsi baik tanpa menggunakan kekerasan

\section{SKOR 1-3}

Banyak terjadi konflik, termasuk kekerasan fisik yang berulang (pembakaran kamp-kamp, pertengkaran di antara berbagai stakeholder, ancaman-ancaman), yang dilaporkan dan beberapa mungkin disaksikan oleh para penilai. Tidak ada mekanisme yang efektif untuk mengatasi konflik (pengadilan tidak berfungsi dengan baik; banyak penyuapan; tidak ada kelompok yang bertindak sebagai seorang hakim yang bebas).

\section{SKOR 4-6}

Konflik terjadi, termasuk kadang berupa kekerasan, tetapi tidak terjadi di semua tempat. Mekanisme penyelesaian konflik berfungsi baik walaupun tidak sempurna. Banyak kasus dapat diselesaikan dengan baik di pengadilan, melalui cara-cara tradisional yang sah, atau melalui perundingan di antara berbagai stakeholder.

\section{SKOR 7-10}

Konflik jarang terjadi, dan bila terjadi dapat diselesaikan dengan baik. Mekanisme penyelesaian konflik jelas, berjalan lancar dan transparan.

I. 1.1.4 Akses terhadap sumber daya dianggap adil oleh masyarakat lokal

\section{SKOR 1-3}

Semua atau beberapa stakeholder tertentu (khususnya para pengelola hutan) terus-menerus mengeluhkan akses yang tidak adil terhadap sumber daya. Mungkin ada juga kelompokkelompok yang jelas-jelas menderita karena ketidakadilan, tetapi tidak mengeluh. Ketidakadilan dalam akses terhadap sumber daya juga jelas terlihat oleh orang-orang lain. 


\section{SKOR 4-6}

Walaupun ada ketidakadilan dalam distribusi sumber daya, kebanyakan para stakeholder menganggap situasinya sedikit banyak dapat diterima. Misalnya, kondisi para karyawan dan penduduk lokal mungkin dianggap lebih baik daripada jika tanpa HPH.

\section{SKOR 7-10}

Hampir semua penduduk yang ditemui menerima bahwa akses terhadap sumber daya adalah adil. Berbagai stakeholder dapat menjelaskan mengapa akses terhadap sumber daya berfungsi demikian dan mereka setuju bila distribusi ini cukup baik atau bahkan baik sekali.

I. 1.1.5 Masyarakat lokal merasakan keamanan aksesnya terhadap sumber daya

\section{SKOR 1-3}

Penduduk secara teratur mengemukakan kekhawatiran tentang akses mereka terhadap sumber daya, baik bagi mereka sendiri dan juga bagi anak-anak mereka. Mereka mungkin menganggap bahwa kedudukan kepemilikan lahan atau hak-hak mereka atas hasil-hasil hutan sangat lemah. Mungkin ada rencana nasional atau daerah untuk mengubah beberapa kawasan mereka menjadi kawasan untuk penggunaan lainnya (perkebunan, transmigrasi, penambangan) yang mereka takutkan mungkin akan sedikit atau sama sekali tidak memberikan manfaat bagi mereka. Penduduk lokal merasa bahwa kualitas sumber daya cepat menurun sehingga yang tersisa untuk masa depan hanya sedikit.

\section{SKOR 4-6}

Walaupun penduduk mengemukakan sedikit kekhawatiran terhadap masa depan, mereka merasa agak aman untuk sementara. Mungkin ada beberapa ancaman, tetapi kelihatannya tidak mengkhawatirkan atau penduduk tidak dapat memastikan implikasi ancaman-ancaman. Masih ada perasaan optimis, umumnya tentang akses sumber daya untuk masa sekarang dan di masa depan. 


\section{SKOR 7-10}

Penduduk sangat terbuka mengemukakan perasaan aman mereka, ketika ditanya tentang akses terhadap sumber daya sekarang dan di masa depan. Mereka secara rutin merencanakan masa depan, misalnya, mereka mau terlibat dalam berbagai kegiatan seperti penanaman pohon-pohon yang pertumbuhannya lambat. Mereka juga mungkin memperbolehkan peminjaman lahan atau memberikan akses terhadap sumber daya mereka yang lain secara periodik. Kekhawatiran tentang isu ini jarang dikemukakan.

\section{K. 1.2 Para pengelola hutan memperoleh manfaat ekonomi yang cukup dari hasil- hasil hutan yang diambilnya $($ Bobot $=15 \%)$}

I. 1.2.1 Mekanisme distribusi manfaat dianggap adil oleh masyarakat lokal

\section{SKOR 1-3}

Tidak ada mekanisme yang dikenal untuk distribusi manfaat, selain sedikit kemungkinan kesempatan kerja bagi penduduk lokal. Umumnya para stakeholder lokal menganggap bahwa sumber daya hutan selalu tersedia secara eksklusif bagi kelompok stakeholder tertentu, yang umumnya kaya atau punya kekuasaan. Masyarakat lokal mungkin memiliki akses yang sangat terbatas atau tidak memiliki akses sama sekali. Para penilai mendengar keluhan-keluhan yang berulang dari berbagai stakeholder tentang ketidakadilan keadaan saat ini, dan ketidakadilan ini sangat jelas (misalnya, suatu perusahaan yang mendapat dukungan pemerintah dan melarang penggunaan hutan secara tradisional).

\section{SKOR 4-6}

Ada beberapa mekanisme pembagian manfaat, seperti berbagai bentuk kontribusi perusahaan untuk mendukung kegiatan pembangunan masyarakat, berbagai kegiatan pembangunan di tingkat masyarakat, akses terhadap kesehatan di kamp kerja. Walaupun sebagian besar keuntungan hutan dinikmati HPH (khususnya keuntungan moneter), penduduk lokal juga 
mendapat manfaat dari hutan. Mereka masih dapat melanjutkan berbagai kegiatan pertanian tradisionalnya (walaupun dengan ketidakpastian dan tidak ada kekuasaan dalam melakukan berbagai perundingan), pengumpulan HHNK, dan penggunaan hutan lainnya, tanpa merasa banyak dirugikan oleh kegiatan-kegiatan HPH.

\section{SKOR 7-10}

Isu distribusi manfaat telah diperhitungkan oleh masing-masing stakeholder lokal, dan telah dicapai cara-cara pembagian manfaat yang memuaskan. Mekanisme-mekanisme yang diterapkan mencakup pengakuan secara formal terhadap hak antargenerasi terhadap kawasan lahan atau jenis tertentu, pembayaran royalti dari perusahaan, pengakuan hak milik intelektual, 'tindakan persetujuan' berupa pemberian pekerjaan kepada masyarakat lokal, dll.

I. 1.2.2 Adanya kesempatan bagi masyarakat lokal dan masyarakat yang menggantungkan hidupnya pada hutan untuk memperoleh pekerjaan dari perusahaan-perusahaan kehutanan ${ }^{5}$

\section{SKOR 1-3}

Hampir semua karyawan HPH berasal dari tempat lain; penduduk lokal tidak memperoleh akses yang semestinya. Beberapa orang yang dipekerjakan umumnya melakukan jenis pekerjaan yang tidak akan membuat mereka berkembang.

5 Ada suatu konflik potensial di antara indikator ini dan usaha untuk memelihara hubungan budaya-hutan atau keragaman budaya. Kadang keterlibatan dalam pekerjaan yang digaji seperti yang disediakan oleh perusahaan HPH menyebabkan masyarakat menjadi terasing dari tradisinya tanpa adanya substitusi yang lebih baik. 


\section{SKOR 4-6}

Walaupun sebagian karyawan HPH berasal dari tempat lain, cukup banyak penduduk lokal yang mendapat kesempatan untuk bekerja di perusahaan-perusahaan. Ada bukti yang menunjukkan bahwa penduduk lokal pun dapat meniti jenjang kerja. Sebagian penduduk lokal mengemukakan keinginannya bekerja di perusahaan.

\section{SKOR 7-10}

Ada perhatian khusus untuk menyediakan prioritas kesempatan kerja di perusahaan bagi penduduk lokal. Perusahaan melakukan berbagai usaha untuk menarik minat penduduk lokal (misalnya, ada kompromi untuk menampung kebutuhan tenaga musiman yang diperlukan dalam agroforestri lokal). Penduduk lokal dapat menduduki posisi yang baik dan bukan sekedar sebagai pekerja kasar.

I. 1.2.3 Upah dan tunjangan lainnya sesuai dengan standar nasional dan/atau ILO

\section{SKOR 1-3}

Upah lebih rendah daripada pekerjaan yang setara di sektor-sektor lain di kawasan yang sama dan lebih rendah daripada standar resmi. Asuransi kesehatan dan asuransi jiwa bahkan tidak dipertimbangkan. Begitu juga libur, cuti sakit atau uang pesangon. 'Kontrak' karyawan mungkin hanya dengan persetujuan lisan. Ada kemungkinan terjadi penipuan dan kegagalan-kegagalan perusahaan untuk menaati berbagai perjanjian dan persetujuan yang tidak resmi ini.

\section{SKOR 4-6}

Perusahan kayu memiliki banyak aturan khusus dalam hal standar gaji dan tunjangan-tunjangan, dan beberapa di antaranya telah diterapkan. Namun masih ada kekurangan perhatian tentang rincian-rinciannya, tindak lanjutnya terlalu sedikit. Para karyawan mungkin tidak tahu banyak tentang hak-hak dan tunjangan-tunjangan mereka, baik di dalam perusahaan atau secara legal. Misalnya, bila upah ditetapkan berdasarkan jumlah kayu yang ditebang per meter kubik, para 
karyawan mungkin tidak tahu bagaimana cara perhitungannya untuk mengetahui berapa hak mereka. Para karyawan yang diperoleh dari kontraktor-kontraktor pihak ketiga mungkin gaji dan tunjangannya lebih rendah dibandingkan dengan gaji karyawan yang bekerja secara langsung di perusahaan.

\section{SKOR 7-10}

Standar nasional atau ILO merupakan bagian yang jelas dari kebijakan perusahaan dan banyak upaya yang dilakukan untuk pelaksanaannya. Untuk pekerjaan serupa, gaji dan tunjangan yang diberikan sama atau lebih baik dari yang diberikan untuk perusahaan yang setara di kawasan yang sama. Asuransi kesehatan dan asuransi jiwa, cuti sakit dan cuti tahunan secara rutin diberikan kepada para karyawan perusahaan. Para karyawan baru diberitahukan tentang hakhak mereka secara transparan. Ada mekanisme untuk memastikan bahwa para karyawan lain (misalnya, di bawah kontrak dengan pihak ketiga) juga menerima gaji dan tunjangan yang cukup.

I. 1.2.4 Ganti rugi terhadap kerusakan diberikan secara adil

\section{SKOR 1-3}

HPH secara teratur menimbulkan kerusakan properti lokal atau mencelakakan penduduk lokal tanpa membayar ganti rugi yang pantas. Kerusakan ini termasuk menewaskan atau mencelakakan penduduk lokal akibat truk atau perahu motor, mematikan pohon-pohon lokal selama pembalakan atau pembangunan jalan, pembangunan jalan melalui hutan-hutan kecil yang keramat, menarik rakit kayu di atas jala-jala penangkap ikan, membuang zat-zat kimia dalam saluran-saluran air lokal. Perusahaan-perusahaan membuka kawasan hutan yang telah digunakan oleh penduduk lokal untuk pertanian tradisional, dan menanam kawasan tersebut dengan jenis tanaman komersial milik perusahaan tanpa membayar ganti rugi. 


\section{SKOR 4-6}

Walaupun HPH kadang merusak milik penduduk lokal, ada mekanisme pemberian ganti rugi yang jelas. Mekanisme-mekanisme ini masih merupakan pokok perdebatan, tetapi ada contohcontoh pemberian ganti rugi yang layak. Mungkin ada ketidaksepakatan yang belum diselesaikan dengan baik.

\section{SKOR 7-10}

Perusahaan kayu mengetahui tentang kepemilikan lokal dan hak-hak untuk menggunakan lahan dan jarang merusak properti penduduk lokal. Bila terjadi kerusakan yang tidak disengaja, ada mekanisme yang transparan untuk menilai dan membayar ganti rugi. Ada juga mekanisme penyelesaian konflik jika ada ketidaksepakatan mengenai ganti rugi.

\section{K. 1.3 Masyarakat mengaitkan masa depan mereka dan anak-anak mereka dengan pengelolaan sumber daya hutan $($ Bobot $=10 \%)$}

I. 1.3.1 Masyarakat menanamkan modal di lingkungannya (misalnya, waktu, tenaga, uang)

\section{SKOR 1-3}

Hampir tidak ada kerjasama masyarakat yang tampak dalam kegiatan untuk kepentingan umum (misalnya, pembangunan gereja-gereja/masjid-masjid, pembersihan jalan, pelaksanaan proyekproyek desa). Penduduk tidak merawat desa, rumah, milik mereka sendiri, atau sumber daya alam lokal dengan baik. Ini berarti bahwa ada kemungkinan mereka akan pindah setiap saat, tanpa perasaan menyesal. Bila penduduk berpendidikan, tujuannya adalah untuk mencari kehidupan yang berbeda di tempat lain.

\section{SKOR 4-6}

Ada beberapa kegiatan masyarakat yang terorganisasi, walaupun dinodai oleh berbagai konflik antarmasyarakat dan ada pendomplengan sampai tingkat tertentu. Penduduk lokal menanamkan 
modal di rumah mereka sendiri, dan juga secara lebih terbatas untuk kepentingan masyarakat yang lebih luas. Mereka menanam pohon-pohon dan tanaman-tanaman perkebunan jangka panjang lainnya. Ada bukti bahwa mereka berharap untuk menetap di kawasan.

\section{SKOR 7-10}

Masyarakat lokal terorganisasi dengan baik dan secara teratur terlibat dalam proyek-proyek kerjasama. Penduduk bangga terhadap lingkungan mereka, dan melakukan usaha-usaha untuk memperbaikinya. Ada cukup banyak pembangunan, dekorasi, dan kemajuan lainnya dalam masyarakat. Penduduk muda dididik agar mereka nanti kembali untuk meningkatkan lingkungan mereka sendiri.

\section{1.3.2 Tingkat migrasi keluar rendah ${ }^{6}$}

\section{SKOR 1-3}

Penduduk mengungsi dari kawasannya. Jumlah populasi turun secara drastis, terutama disebabkan oleh migrasi keluar, dan penduduk mendorong anak-anak mereka untuk mencari kesempatan-kesempatan yang lebih baik di tempat lain.

\section{SKOR 4-6}

Penduduk merasakan godaan 'kegemerlapan kota' karena alasan keuangan atau sebab-sebab lain, dan ada keinginan-keinginan untuk terlepas dari kesukaran hidup di hutan, tetapi kebanyakan mereka bertahan, walaupun orang tua merasakan beberapa keuntungan kehidupan

6 Indikator 1.3.2 dan 3.1.2 berpotensi untuk kontradiktif. Tingkat migrasi keluar yang rendah (I. 1.3.2) mengindikasikan bahwa penduduk mengaitkan masa depan penduduk dan anakanak mereka dengan pemeliharaan hutan; sementara itu pemahaman tentang perlunya keseimbangan antara jumlah penduduk dengan penggunaan sumber daya alam (I. 3.1.2) mungkin membuat mereka memilih untuk bermigrasi keluar. Kontradiksi ini kemungkinan besar terjadi ketika kondisi-kondisi memburuk. 
kota, mereka cenderung membesarkan anak-anak mereka dengan harapan bahwa mereka dapat menetap di daerahnya dan menjalani kehidupan yang berhubungan dengan hutan.

\section{SKOR 7-10}

Hanya beberapa penduduk yang meninggalkan daerahnya karena ada kepentingan lain atau ketidakpuasan terhadap kehidupan di hutan. Anak-anak diajar ketrampilan-ketrampilan yang sesuai dengan kondisi lokal dan untuk menghargai cara-cara kehidupan mereka.

I. 1.3.3 Masyarakat menyadari pentingnya keseimbangan antara jumlah penduduk dengan pemanfaatan sumber daya alam

\section{SKOR 1-3}

Tingkat pertambahan jumlah penduduk tinggi, sehingga menimbulkan masalah bagi lingkungan mereka. Ukuran-ukuran keluarga besar merupakan norma umum, banyak anak yang tetap tinggal di daerahnya dan menjalankan gaya hidup yang mengandalkan sumber daya alam lokal. Penduduk tidak menyadari adanya hubungan antara jumlah penduduk dan sumber daya alam yang menjadi andalan mereka.

\section{SKOR 4-6}

Ada pertumbuhan penduduk dan ada beberapa tekanan terhadap sumber daya alam, tetapi keadaannya tidak mengkhawatirkan. Penduduk mengetahui hubungan antara jumlah penduduk dan penggunaan sumber daya, tetapi hanya ada sedikit mekanisme untuk tetap menjaga keseimbangannya. Mungkin ada beberapa alternatif lain.

\section{SKOR 7-10}

Penduduk dengan tegas menyatakan kepentingan keseimbangan antara sumber daya alam dengan populasi penduduk dan penggunaan lahan. Ada mekanisme-mekanisme efektif untuk 
penggunaan lahan secara lebih intensif dan/untuk menstabilkan tingkat populasi penduduk (misalnya, program keluarga berencana yang efektif; migrasi keluar yang cukup besar; pembangunan alternatif-alternatif lokal agar tidak bergantung pada sumber daya alam atau penggunaan sumber daya yang lebih efisien).

I. 1.3.4 Anak-anak mendapatkan pendidikan (formal dan informal) tentang pengelolaan sumber daya alam

\section{SKOR 1-3}

Orang dewasa tidak memiliki pengetahuan yang berhubungan dengan pengelolaan sumber daya alam lokal (termasuk pengetahuan indijenus) atau mereka tidak mengajarkan pengetahuan tersebut kepada anak-anak mereka. Dalam beberapa kasus, pendidikan indijenus telah disepelekan selama beberapa dekade, sehingga pengetahuan ini hilang atau 'mati', dan proses pendidikan formal tidak tersedia.

\section{SKOR 4-6}

Tingkat pengetahuan (indijenus, formal atau kombinasi keduanya) cukup dapat diterima, dan beberapa mekanisme untuk mewariskannya tetap ada. Namun masalah tetap ada. Pengetahuan indijenus yang bermanfaat mungkin tidak diakui oleh penduduk yang terdidik; pengetahuan formal yang kurang tepat mungkin lebih besar peranannya dan diterapkan dengan cara-cara yang merusak; pendidikan formal yang menghabiskan waktu mungkin mengurangi kesempatan untuk menularkan pengetahuan indijenus secara informal.

\section{SKOR 7-10}

Orang dewasa memiliki cukup banyak pengetahuan tentang sumber daya alam dan pengelolaannya, dan pengetahuan ini diturunkan kepada anak-anak mereka. Generasi selanjutnya tertarik untuk belajar dan memperoleh manfaat dari pengetahuan indijenus tersebut. Pengetahuan indijenus yang bermanfaat mungkin diintegrasikan dalam program pendidikan formal; mungkin 
ada pemaduan kedua jenis pengetahuan ini; atau salah satu dari pengetahuan tentang pengelolaan sumber daya alam berhasil ditularkan kepada generasi selanjutnya.

I. 1.3.5 Perusakan sumber daya alam oleh masyarakat lokal jarang terjadi

\section{SKOR 1-3}

Contoh perusakan biasa dilaporkan dan kadang dijumpai saat kunjungan-kunjungan ke lapangan. Orang-orang muda mungkin secara tidak bertanggung jawab membakar kawasan tetangga; ${ }^{7}$ mungkin membakar karena dendam (ketidakpuasan); memancing dengan racun komersial umum dilakukan; pengumpulan hasil-hasil hutan dilakukan secara sembrono. Penduduk lokal tidak mengakui bahwa perusakan seperti ini serius dan/atau mereka tidak merasa bahwa mereka dapat melakukan apa-apa untuk mengatasinya.

\section{SKOR 4-6}

Perusakan kadang terjadi tetapi bukan hal yang biasa. Perusakan semacam ini diakui sebagai masalah, dan ada usaha-usaha yang dilakukan untuk mengatasinya (walaupun tidak selalu berhasil).

\section{SKOR 7-10}

Peristiwa-peristiwa perusakan jarang terjadi, dan penduduk menganggap perusakan terhadap sumber daya alam sebagai sesuatu yang buruk. Ketika ada penduduk yang melakukan perusakan, ada mekanisme untuk menghukum mereka dan mengharuskan mereka melakukan perbaikan.

7 Satu kelemahan: Di banyak kawasan hutan basah tropis di mana peladangan berpindah umum dilakukan, pembakaran hutan untuk membuka lahan pertanian adalah bagian proses yang lestari, hanya menyebabkan kerusakan sementara dari bagian daur yang berulang dan tidak mengganggu daur berikutnya. 
I. 1.3.6 Masyarakat memelihara hubungan batin dengan lahan hutan

\section{SKOR 1-3}

Semua hubungan batin terhadap (atau hubungan lain yang memotivasi penduduk untuk memiliki rasa tanggung jawab atau perasaan keutuhan) lahan telah dihancurkan (atau bahkan tidak pernah ada). Penduduk melihat diri mereka sendiri sebagai bagian yang benar-benar terpisah dari hutan di mana mereka tinggal. Mereka tidak mengakui tanggung jawab terhadap kesehatan hutan mereka.

\section{SKOR 4-6}

Hubungan batin dengan lahan hutan ada, tetapi sering dianggap kurang penting dibandingkan dengan manfaat ekonomi lahan dan hutan. Ada beberapa upacara agama yang mencerminkan hubungan masyarakat dengan hutan, tetapi mungkin makin jarang dilakukan (karena diejek oleh orang lain atau oleh para stakeholder lain yang lebih kuat). Atau penduduk di daerah yang bersangkutan merupakan pendatang baru yang berasal dari daerah yang tidak berhutan.

\section{SKOR 7-10}

Hutan dianggap mempunyai nilai spiritual/budaya dan pemeliharaannya diterima sebagai bagian yang penting bagi kehidupan masyarakat. Mereka menyadari ketergantungannya terhadap hutan dan memiliki rasa tanggung jawab atau tugas untuk merawat hutan. Upacara agama dan bukti lain adanya hubungan ini mungkin terlihat selama kunjungan lapangan berlangsung dan/atau dapat dijelaskan oleh penduduk lokal. Ada bukti-bukti bahwa nilai ini diturunkan kepada generasi-generasi muda. 


\section{P. 2 STAKEHOLDER YANG RELEVAN MEMILIKI H AK DAN KEMAMPUAN YANG DIAKUI UNTUK MENGELOLA HUTAN SECARA BERSAMA DAN ADIL (NILAI TOTAL $=\mathbf{3 0} \%$ )}

K. 2.1 Adanya berbagai mekanisme yang efektif untuk melakukan komunikasi dua arah antara para stakeholder dalam kaitannya dengan pengelolaan hutan $($ Bobot $=10 \%)$

I. 2.1.1 > 50\% dari pegawai Departemen Kehutanan dan Perkebunan dan karyawan HPH dapat berbicara dalam satu atau beberapa bahasa lokal, atau $>50 \%$ wanita lokal ${ }^{8}$ dapat menggunakan bahasa yang digunakan oleh HPH dalam berinteraksi

\section{SKOR 1-3}

Hampir tidak ada karyawan HPH atau pegawai Departemen Kehutanan dan Perkebunan yang dapat berbicara dalam bahasa lokal dan hampir tidak ada penduduk lokal yang dapat berbicara dalam bahasa yang digunakan oleh karyawan HPH atau pegawai Departemen kehutanan.

\section{SKOR 4-6}

Jumlah stakeholder yang berbicara dalam bahasa yang sama semakin banyak, tetapi masih banyak yang tidak demikian. Ini khususnya terjadi di antara para wanita (yang kemungkinan besar tidak dapat berbicara dalam bahasa nasional).

\section{SKOR 7-10}

Hampir semua stakeholder lokal paling sedikit memiliki satu bahasa yang sama.

8 Ketrampilan bahasa pada para wanita khususnya merupakan indikator yang sangat baik karena wanita yang paling sering tersisih dibandingkan dengan para pria lokal dalam interaksi mereka dengan orang luar, seperti pegawai perusahaan kayu. 
I. 2.1.2 Para stakeholder lokal bertemu dengan frekuensi yang cukup, keragaman lokal cukup terwakili, dan dengan kualitas interaksi yang cukup

\section{SKOR 1-3}

Anggota stakeholder/kelompok-kelompok pengguna hutan yang berbeda jarang atau tidak pernah bertemu. Banyak yang menunjukkan keengganan untuk melakukannya.

\section{SKOR 4-6}

Terjadi komunikasi di antara berbagai stakeholder lokal (walaupun para wanita kemungkinan tidak cukup terwakili, demikian juga kelompok-kelompok etnis yang tersisih), dengan tidak lancar atau tegang. Proses komunikasi ini tidak mudah.

\section{SKOR 7-10}

Ada banyak kesempatan di mana berbagai stakeholder secara sukarela bertemu dan berdiskusi tentang isu-isu yang berhubungan dengan pengelolaan hutan di kawasan yang bersangkutan. Kesempatan ini melibatkan para wanita dan wakil-wakil dari kelompok-kelompok yang tersisih (jika ada) yang berinteraksi secara proaktif dengan stakeholder lainnya. Ada rasa saling menghormati di antara para peserta.

\section{2.1.3 Kontribusi masing-masing stakeholder saling dihormati dan dihargai secara wajar}

\section{SKOR 1-3}

Dalam kesempatan yang jarang terjadi di mana berbagai stakeholder bertemu, interaksi mereka ditandai oleh kondisi sosial yang tidak menyenangkan. Suasana yang umum terjadi adalah sikap pegawai-pegawai HPH yang meremehkan dan masyarakat lokal merasa takut atau takluk. Atau kedua pihak ini sama-sama saling meremehkan, takut, marah, curiga dan/atau dendam, yang dikemukakan secara terbuka. 


\section{SKOR 4-6}

Masih ada bukti-bukti interaksi di antara stakeholder yang saling meremehkan dan bermusuhan (misalnya, pihak yang kuat meremehkan; pihak yang lemah merasa ketakutan), tetapi juga ada bukti bahwa pihak yang lemah dapat mengemukakan kehendaknya dan merundingkan keinginan mereka hingga terpenuhi. Para stakeholder lokal mungkin menunjukkan permusuhan antara satu sama lain, tetapi mengakui sebagian kontribusi dan hak-hak stakeholder yang lain.

\section{SKOR 7-10}

Hanya sedikit bukti adanya tingkah laku negatif pegawai-pegawai perusahaan atau dari anggota masyarakat dan para karyawan. Para stakeholder secara bebas mengemukakan rasa hormat mereka satu sama lain. Mungkin juga ada perubahan sosial perseorangan dari satu kelompok stakeholder ke kelompok yang lain.

\section{K. 2.2 Para stakeholder memiliki pengetahuan yang lengkap tentang penggunaan sumber daya hutan (termasuk pengetahuan tentang kelompok-kelompok pengguna hutan dan peranan jender), dan juga pengetahuan tentang rencana pengelolaan hutan sebelum rencana tersebut dilaksanakan $($ Bobot $=10 \%)$}

I. 2.2.1 Adanya rencana/peta-peta yang menunjukkan pengintegrasian berbagai penggunaan hutan oleh berbagai stakeholder yang berbeda

\section{SKOR 1-3}

Rencana-rencana dan peta-peta perusahaan (jika ada) tidak memberi indikasi adanya keterlibatan stakeholder lain. Mungkin rencana-rencana dan peta-peta perusahaan dibuat jauh dari lokasi, dan tidak ditemukan masukan dari stakeholder lokal. Tidak ada mekanisme untuk mendapatkan masukan lokal. 


\section{SKOR 4-6}

Rencana-rencana dan peta-peta telah dibuat secara lokal dengan beberapa masukan dari penduduk lokal. Mungkin tidak semua jenis pemanfaatan hutan oleh penduduk lokal di masukkan, tetapi ada beberapa kemajuan ke arah ini. Penduduk lokal dapat menerangkan bagaimana masukan tersebut disampaikan dan karyawan-karyawan perusahaan dapat menjelaskan bagaimana mereka mendapatkan masukan-masukan dari masyarakat lokal.

\section{SKOR 7-10}

Rencana-rencana/peta-peta yang tersedia di perusahaan jelas memperlihatkan berbagai jenis pemanfaatan hutan oleh berbagai stakeholder. Ada mekanisme untuk memperbarui rencanarencana/peta-peta tersebut secara teratur.

I. 2.2.2 Rencana yang diperbarui, studi-studi dasar dan peta dapat diperoleh dengan mudah, yang menunjukkan rincian kawasan seperti penebangan hutan dan pembangunan jalan, disertai kerangka waktunya

\section{SKOR 1-3}

Tidak ada rencana, studi dasar dan peta tentang pemanfaatan sumber daya alam baik di desa, di kantor-kantor lokal, atau di dinding-dinding atau papan-papan pengumuman lokal.

\section{SKOR 4-6}

Berbagai rencana, studi dan peta pernah dilihat oleh penduduk lokal, tetapi jarang. Tidak selalu mudah untuk memperoleh akses terhadap sumber informasi. Atau kebanyakan informasi ini tidak lengkap (misalnya, memperlihatkan kawasan-kawasan penebangan tanpa menunjukkan kerangka waktunya). 


\section{SKOR 7-10}

Setiap desa yang dikunjungi memiliki informasi berbagai rencana dan kegiatan HPH yang hampir lengkap, dan/atau penduduk tahu di mana mereka bisa mendapatkan dan memperbarui informasi ini dengan mudah.

I. 2.2.3 Studi-studi dasar tentang sistem masyarakat lokal juga tersedia dan diacu

\section{SKOR 1-3}

Tidak ada studi tentang sistem kemasyarakatan lokal di dalam atau di dekat HPH, dan tidak ada pegawai HPH yang pernah mendengar tentang studi seperti ini.

\section{SKOR 4-6}

HPH telah melihat beberapa studi, dan bahkan melakukannya sendiri (mungkin diharuskan oleh program pemerintah). Dalam beberapa hal, studi mungkin dilakukan oleh mereka yang berlatar belakang pendidikan sebagai rimbawan dibandingkan sebagai ilmuwan sosial, dan hasil studi mengenai penduduk lokal agak bias (mereka sering menekankan 'keterbelakangan' atau 'keprimitifan' atau 'kemampuan sumber daya manusia yang rendah' daripada menekankan pengetahuan indijenus mereka atau potensi kontribusi mereka terhadap pengelolaan sumber daya alam di kawasan tersebut).

\section{SKOR 7-10}

Kantor HPH memiliki perpustakaan kecil yang menyimpan informasi tentang masyarakat di kawasannya dan tentang karyawan mereka sendiri. Informasi ini mungkin meliputi studi etnografi, laporan-laporan pemerintah dan LSM, makalah yang ditulis oleh para pakar dalam berbagai bidang, laporan konsultan, dll. Pustaka yang ada mencerminkan keragaman perspektif termasuk laporan yang menyebutkan hal-hal yang baik tentang penduduk lokal. 
I. 2.2.4 Pegawai pengelola hutan mengakui adanya berbagai kepentingan dan hak stakeholder lainnya

\section{SKOR 1-3}

Staf pengelola HPH terus-menerus menuntut hak-hak perusahaan dan di atas hak-hak stakeholder lainnya. Penduduk lokal dianggap sebagai 'perambah', 'penebang liar', 'pemburu-pemburu gelap', dan sebutan-sebutan yang tidak layak lainnya yang mencerminkan bahwa penduduk lokal tidak memiliki kepentingan dan hak-hak yang sah di dalam kawasan.

\section{SKOR 4-6}

Pihak pengelola HPH baru saja mulai mengakui bahwa stakeholder-stakeholder lain mungkin memiliki kepentingan dan hak-hak di dalam kawasan, dan mereka telah mulai mencoba untuk menerima kepentingan dan hak-haknya itu. Namun, mereka tetap sering kembali pada kebiasaan 'jelek', menggunakan istilah yang mencerminkan pandangan yang tertutup terhadap pengelolaan hutan. Mereka juga sering berusaha untuk mengacu kepada hukum-hukum negara (yang dalam banyak kasus tidak mengakui kepentingan-kepentingan dan hak-hak dari stakeholder-stakeholder lain).

\section{SKOR 7-10}

Sebagian besar staf pengelola HPH menyatakan bahwa ada berbagai stakeholder yang memiliki kepentingan dan hak-hak yang sah dalam pengelolaan hutan. Perspektif ini dapat dilihat dari istilah-istilah yang mereka gunakan, pernyataan-pernyataan yang mereka buat, dan dari literatur yang mereka berikan kepada penilai untuk dibaca. 
I. 2.2.5 Pengelolaan Hasil Hutan Nonkayu (HHNK) mencerminkan kepentingan dan hak-hak stakeholder lokal

\section{SKOR 1-3}

Isi rencana-rencana pengelolaan perusahaan mungkin sama sekali tidak menyebutkan HHNK; atau mereka memiliki peraturan yang mengatur penggunaan HHNK oleh mereka sendiri, dengan mengabaikan penggunaan HHNK oleh stakeholder-stakeholder lain. Tidak ada mekanisme untuk memperoleh masukan dari stakeholder-stakeholder lain dan tidak ada bukti bahwa mereka peduli terhadap kelestarian HHNK.

\section{SKOR 4-6}

Ada sedikit perhatian terhadap HHNK dalam rencana-rencana pengelolaan, tetapi pembahasan tentang pemanfaatan oleh penduduk lokal tidak lengkap. Pembahasan tentang HHNK mungkin juga tidak lengkap (misalnya, hanya memfokuskan pada satu jenis yang diminati oleh HPH ). Mungkin ada mekanisme yang tidak memadai untuk memperoleh masukan dari semua kelompok-kelompok pengguna yang relevan (terutama para wanita atau kelompok-kelompok yang tersisih).

\section{SKOR 7-10}

Di dalam rencana-rencana pengelolaan perusahaan ada pembahasan tentang HHNK yang jelas, disertai dengan tanggung jawab dan hak-haknya. Kelestarian sumber daya HHNK juga dibahas dalam rencana pengelolaan. Ada perhatian yang cukup mengenai pemanfaataan oleh stakeholderstakeholder lain, dan ada mekanisme yang menunjukkan cara-cara mandapatkan masukan dari berbagai stakeholder. 


\section{K. 2.3 Ada kesepakatan tentang hak-hak dan berbagai kewajiban stakeholder yang relevan $($ Bobot $=10 \%)$}

I. 2.3.1 Tingkat konflik yang ada dapat diterima oleh para stakeholder

\section{SKOR 1-3}

Konflik tajam dan sering terjadi. Masing-masing stakeholder mempunyai cerita yang berbeda tentang masalah-masalah terakhir dengan stakeholder-stakeholder lain. Penduduk mengakui ada banyak konflik, dan menyatakan bahwa mereka tidak mampu menyelesaikannya.

\section{SKOR 4-6}

Berbagai konflik seputar hak dan tanggung jawab stakeholder yang berbeda bukan hal yang tidak umum. Namun sumber-sumber konflik diketahui dan prosedur penyelesaian konflik paling tidak sebagian dapat diterima. Mungkin ada keragu-raguan bahwa stakeholder-stakeholder yang berbeda dalam kenyataannya akan melaksanakan tanggung jawab mereka dan mungkin ada kecurigaan bahwa stakeholder ini melampaui hak-hak mereka.

\section{SKOR 7-10}

Konflik hampir tidak ada. Atau mungkin ada beberapa konflik, tetapi ada kesepakatan umum tentang hak-hak dan tanggung jawab untuk mengelola hutan. Berbagai konflik dipahami, dan ada mekanisme untuk memecahkannya. Semua pihak cukup mempercayai mekanismemekanisme ini. 


\begin{tabular}{|ll|}
\hline P. 3 & $\begin{array}{l}\text { KESEHATAN HUTAN, PARA PENGELOLA HUTAN DAN BUDAYANYA } \\
\text { DAPAT DITERIMA OLEH SEMUA STAKEHOLDER (NILAI TOTAL }= \\
\text { 30\%) }\end{array}$ \\
\hline K. 3.1 & $\begin{array}{l}\text { Ada keseimbangan yang cukup baik antara berbagai kegiatan } \\
\text { manusia dan kondisi lingkungannya (Bobot }=\mathbf{1 0} \%)\end{array}$ \\
\hline $\begin{array}{l}\text { I. } 3.1 .1 \\
\text { Berbagai kondisi lingkungan yang dipengaruhi oleh kegiatan manusia tetap } \\
\text { dalam keadaan stabil atau membaik }\end{array}$ \\
\hline
\end{tabular}

\section{SKOR 1-3}

Sistem pemanfaatan sumber daya alam mengalami keruntuhan. Misalnya, siklus masa bera untuk peladangan berpindah berkurang secara drastis; masalah-masalah kesuburan tanah dan erosi merajalela; kebakaran yang tidak terkendali sering terjadi; tingkat produksi hasil hutan (HHNK, ikan, satwa liar) telah menurun secara dramatis dalam tahun-tahun terakhir; keanekaragaman hayati berkurang.

\section{SKOR 4-6}

Sistem pemanfaatan sumber daya alam masih berfungsi tetapi ada tanda-tanda masalah potensial. Panjang masa bera telah berkurang, walaupun tidak tajam. Mungkin muncul beberapa masalah kesuburan tanah dan erosi. Penduduk tetap mengumpulkan HHNK (termasuk ikan dan satwa liar), tetapi mereka mengeluh bahwa jumlahnya lebih sedikit dibandingkan sebelumnya.

\section{SKOR 7-10}

Sistem pemanfaatan sumber daya alam (terutama pertanian) dalam keadaan baik. Siklus masa bera pada sistem peladangan berpindah cukup lama untuk mempertahankan dan/atau untuk

9 Indikator-indikator ini jelas berhubungan erat dengan indikator ekologi, tersedia di bagian lain. 
meningkatkan kesuburan tanah. Kebakaran dapat dikendalikan dengan baik pada tingkat yang dianggap baik oleh penduduk lokal. Hasil penangkapan ikan dan perburuan baik (setara, atau lebih baik daripada waktu yang lalu). HHNK tetap sebaik seperti sebelumnya (atau lebih baik).

I. 3.1.2 Migrasi masuk dan/atau pertambahan penduduk secara alami selaras dengan pemeliharaan hutan

\section{SKOR 1-3}

Terjadi arus migrasi masuk yang dramatis dari kawasan lain yang merencanakan untuk hidup dengan mengandalkan sumber daya alam lokal; dan/atau telah terjadi peningkatan jumlah populasi alami yang dramatis, tanpa alternatif lain selain mengandalkan sumber daya alam lokal. Tidak ada program-program pemerintah yang membantu penduduk untuk mendapatkan pelayanan program keluarga berencana, atau tidak ada strategi pola penghidupan subsisten yang tidak hanya mengandalkan sumber daya alam di kawasan.

\section{SKOR 4-6}

Tingkat populasi agak meningkat, dan ada kekhawatiran bahwa 'daya dukung lingkungan' sudah terlampaui (konsep ini sulit didefenisikan). Penduduk mengakui kekurangan lahan untuk kebutuhan pertaniannya tetapi kondisinya belum kritis. Mungkin ada rencana pemerintah dan perusahaan swasta untuk mendatangkan keluarga-keluarga tambahan ke dalam kawasan (atau migrasi swakarsa), dengan perhatian terhadap isu-isu kependudukan dan lahan. Program keluarga berencana mungkin tersedia di beberapa tempat, tetapi tidak ada di tempat lain; atau mungkin ada kesulitan-kesulitan dalam menerima program keluarga berencana dengan alasan-alasan lain, walaupun upaya untuk menyediakannya terus dilakukan.

\section{SKOR 7-10}

Tingkat populasi stabil dan sesuai dengan lingkungan lokal; atau alternatif lain untuk mata pencaharian yang tidak bergantung langsung pada penggunaan sumber daya alam lokal telah 
berhasil ditemukan (intensifikasi pertanian yang berhasil ${ }^{10}$, pembangunan industri atau pariwisata sedikit). Ada sedikit keprihatinan terhadap ketersediaan lahan untuk kebutuhan subsisten. Rencana-rencana pemerintah dan industri swasta untuk kawasan ini mengakui kebutuhan untuk menyeimbangkan populasi manusia dengan sumber daya lokal. Program keluarga berencana tersedia dan cukup diterima dengan baik oleh stakeholder-stakeholder lokal.

\section{K. 3.2 Ada pengakuan terhadap hubungan antara kesehatan masyarakat dengan pengelolaan hutan $($ Bobot $=10 \%)$}

I. 3.2.1 Pihak pengelola hutan bekerjasama dengan pegawai kesehatan masyarakat dalam mengatasi berbagai penyakit yang berkaitan dengan pengelolaan hutan

\section{SKOR 1-3}

Tidak ada hubungan antara pegawai kesehatan masyarakat dengan $\mathrm{HPH}$, terutama yang berhubungan dengan kegiatan-kegiatan di perusahaan. Contohnya meliputi 1) AIDS dan penyakit-penyakit yang disebarkan melalui hubungan seks yang merajalela karena ketidakseimbangan rasio jenis kelamin dan menyebabkan pelacuran di kamp-kamp pembalakan, 2) penyakit malaria dan penyakit lain yang ditularkan oleh nyamuk meningkat karena praktekpraktek pembalakan yang buruk (khususnya penggenangan dan terganggunya habitat-habitat pemangsa nyamuk), 3) pencemaran udara karena pembakaran lahan untuk mendirikan industri pulp dan kertas telah meningkatkan masalah gangguan pernafasan dan mata, 4) kecelakaankecelakaan karena pembalakan umum terjadi, dan/atau 5) kekerasan antara para karyawan dari kelompok-kelompok etnis yang berbeda merupakan ciri kehidupan di kamp kerja.

${ }^{10}$ Istilah 'berhasil' penting di sini, karena kebanyakan usaha yang dilakukan di kawasan tropis masih belum berhasil. 


\section{SKOR 4-6}

Pegawai kesehatan masyarakat memiliki hubungan dengan HPH, walaupun tidak banyak. Perusahaan menyediakan pelayanan kesehatan kepada penduduk di kawasan, tetapi tidak bertanggung jawab penuh untuk memantau masalah-masalah kesehatan yang berkaitan dengan berbagai kegiatan pembalakan. Mereka mungkin mempunyai pandangan yang sangat sempit tentang tanggung jawabnya (misalnya, hanya kecelakaan yang berkaitan dengan pembalakan); atau mereka mungkin melakukan pemantauan dan pengumuman yang tidak merata. Masih ada masalah-masalah, tetapi tidak terlalu berat: kecelakaan, kekerasan antaretnis, penyakit yang ditularkan melalui hubungan seks, pencemaran air dan udara dan penyakit yang disebarkan oleh nyamuk.

\section{SKOR 7-10}

Pegawai kesehatan masyarakat menyimpan laporan-laporan tentang kesehatan penduduk yang tinggal di dalam dan dekat hutan berdasarkan informasi yang sebagian disediakan oleh perusahaan HPH; perusahaan juga mempunyai klinik kesehatan sendiri dan pegawai lain, dan juga menyediakan perawatan obat gratis, terutama untuk masalah kesehatan yang berhubungan langsung dengan berbagai kegiatan perusahaan. Jumlah insiden penyakit AIDS, penyakit yang ditularkan melalui hubungan seks, malaria, demam, kecelakaan dan masalah/penyakit lain yang berkaitan dengan kegiatan pembalakan tetap atau berkurang.

I. 3.2.2 Status gizi masyarakat lokal cukup baik (misalnya, tingkat pertumbuhan tinggi dan berat badan anak-anak sesuai dengan standar internasional, tingkat kematian bayi dan balita rendah)

\section{SKOR 1-3}

Sebagian besar menu makanan adalah zat tepung dan keragaman dan/atau jumlah tidak mencukupi. Gemuk dianggap cantik. Kekurangan gairah umum terjadi. Ada banyak contoh di mana ditemukan gondok, rabun senja, keletihan kronis dan penyakit kronis seperti malaria dan 
tuberkolosis. Pertumbuhan anak-anak mungkin jauh lebih lambat dibandingkan dengan tinggi/ berat badan menurut standar internasional dan/atau mereka menderita perut buncit dan lengan yang kurus. Angka kematian bayi dan anak balita tinggi. Para wanita menderita anemia dan memperlihatkan tanda-tanda kekurangan kalsium, khususnya selama kehamilan.

\section{SKOR 4-6}

Walaupun secara umum makanan cukup, penduduk yang lebih tua dan anak-anak yang muda tetap terlalu kurus. Kelihatannya para wanita aktif yang sedang hamil mengeluh sakit tulang selama kehamilannya. Masalah gigi merupakan hal yang umum untuk semua usia (termasuk yang kehilangan semua gigi pada usia muda). Menu makanan lokal mungkin sangat tergantung pada karbohidrat atau yang terlalu banyak mengandung gula, kafein dan/atau alkohol.

\section{SKOR 7-10}

Penduduk dapat makan tiga kali sehari, dan menu makanannya berbeda-beda (termasuk semua vitamin dan mineral penting, protein dan sumber energi). Kebanyakan penduduk tampak sehat dan kuat. Konsumsi gula, kopi dan/atau alkohol umumnya pada batas-batas yang sehat. Tingkat kematian dan kecacatan rendah untuk semua kelompok umur.

I. 3.2.3 Para pegawai yang bekerja di bidang kehutanan memperhatikan persyaratanpersyaratan dan keamanan kerja sesuai dengan standar ILO dan bertanggung jawab atas risiko kesehatan yang berkaitan dengan pekerjaan mereka

\section{SKOR 1-3}

Hampir tidak ada karyawan pembalak yang terlihat menggunakan perlengkapan pengaman (topi baja, sepatu bot baja, celana jins, sarung tangan); kondisi peralatan kerja yang digunakan memprihatinkan; penjaga keamanan dan tanda-tanda keamanan telah dihapuskan dari peralatan pembalakan; supir truk jelas sembrono. Pengelola perusahaan dan mandor tampak tidak peduli terhadap keselamatan karyawan. Tidak ada prosedur pelatihan atau pedoman keselamatan kerja. 
Tidak ada fasilitas perawatan kesehatan di kamp kerja. Kematian karena kecelakaan umum terjadi dan dianggap bukan tanggung jawab perusahaan.

\section{SKOR 4-6}

Perusahaan memiliki peraturan keselamatan kerja tetapi dilaksanakan secara acak-acakan. Kepatuhan terhadap peraturan keselamatan tergantung pilihan perseorangan, sehingga angka kecelakaan tinggi. Perusahaan menerima tanggung jawab untuk kecelakaan dan/atau kematian tetapi mungkin tidak membayar ganti rugi yang dijanjikan secara konsisten. Mungkin ada sedikit atau tidak ada pelatihan formal tentang keselamatan kerja; dan persediaan peralatan keselamatan dan perawatannya tidak memadai. Perawatan kesehatan yang tersedia di kamp kerja sedikit sekali.

\section{SKOR 7-10}

Perusahaan telah melakukan program pelatihan untuk semua karyawan baru dan kursus-kursus penyegaran untuk pekerja-pekerja yang lama dengan fokus pada keselamatan kerja. Perusahaan menyediakan peralatan keamanan kerja untuk para karyawannya dan memiliki prosedur yang jelas untuk menjamin peralatan tersebut diperiksa secara teratur keamanannya dan perilaku para karyawan dipantau sesuai syarat-syarat dalam peraturan keselamatan kerja. Ada sanksi khusus yang dikenakan bagi karyawan yang tidak mengikuti peraturan keselamatan kerja. Perusahaan bertanggung jawab secara finansial terhadap kecelakaan, kerugian dan/ atau kematian melalui asuransi atau mekanisme lain. Kamp kerja memiliki peralatan klinik yang lengkap untuk merawat cedera yang berat. Tanda-tanda peringatan untuk mengingatkan para karyawan tentang isu-isu keselamatan kerja tampak di lokasi kerja. 


\section{K. 3.3 Ada pengakuan terhadap pentingnya keterkaitan antara pemeliharaan hutan dengan kebudayaan $($ Bobot $=10 \%)$}

I. 3.3.1 Para pengelola hutan dapat menjelaskan keterkaitan antara budaya masyarakat dengan hutan lokal

\section{SKOR 1-3}

Para pengelola perusahaan menunjukkan ketidakpedulian dan tidak menghormati budaya penduduk lokal (kepercayaan, norma-norma, dan adat istiadat). Mereka cenderung tidak mempedulikan kehidupan penduduk lokal, bahkan sering menganggap mereka terbelakang atau bahkan menjijikkan. Mereka mungkin tidak tahu bahwa penduduk lokal memiliki pengetahuan tentang hutan mereka.

\section{SKOR 4-6}

Walaupun ada kesadaran di pihak pegawai-pegawai perusahaan bahwa penduduk lokal mempunyai gaya hidup sendiri, dan ada beberapa elemen positif dari budaya mereka, pengetahuan ini sangat tidak lengkap. Mungkin masih ada perasaan bahwa penduduk lokal lebih rendah (mungkin karena tingkat kebudayaannya rendah, kekuatan atau keahlian teknologi mereka rendah). Keterbukaan mereka terhadap keterlibatan penduduk lokal dalam pengelolaan mungkin terbatas pada pendekatan top down, di mana perusahaan adalah pihak yang 'berkuasa dan menentukan'.

\section{SKOR 7-10}

Para pengelola hutan tahu tentang budaya tradisional lokal. Misalnya, mereka mampu menjelaskan hubungan antara masa bera yang panjang dalam sistem agroforesti penduduk dengan regenerasi tanah. Atau mereka tahu tentang pandangan umum penduduk lokal tentang perananperanan jenis tertentu dalam hutan; tentang kawasan yang tabu untuk dimasuki; pengetahuan indijenus penduduk lokal tentang perilaku satwa liar dan pengelolaannya. Ada pengakuan yang luas di antara pegawai-pegawai perusahaan bahwa pengalolaan hutan lestari akan membutuhkan 
pengetahuan, nilai-nilai dan tindakan dari penduduk lokal, sama seperti yang diberikan oleh stakeholder-stakeholder lainnya.

I. 3.3.2 Rencana-rencana pengelolaan hutan mencerminkan perhatian terhadap isuisu yang terkait dengan kebudayaan

\section{SKOR 1-3}

Rencana-rencana pengelolaan hutan tidak mencantumkan kompromi atau pengakuan terhadap pemanfatan hutan untuk kepentingan budaya penduduk lokal. Hutan-hutan keramat, pemakaman, tempat lain yang disisihkan untuk generasi mendatang dibalak tanpa konsultasi dengan penduduk lokal. Daerah-daerah pelacuran yang didukung perusahaan mungkin didirikan di tempat-tempat yang berbatasan dengan masyarakat. Masyarakat banyak mengeluh tentang kelakuan para karyawan perusahaan.

\section{SKOR 4-6}

Ada pengertian dan kepedulian perusahaan terhadap isu-isu budaya lokal. Walaupun rencanarencana pengelolaan hanya mencantumkan sebagian dari isu-isu budaya, ada bukti bahwa perusahaan merasa bertanggung jawab terhadap isu-isu budaya ini. Bila masalah-masalah muncul, diadakan pertemuan bersama penduduk lokal untuk membicarakan ganti rugi; tetapi banyak kendalanya (misalnya, pertemuan diadakan setelah kawasan dibalak; atau ganti rugi yang diberikan dianggap tidak adil; atau ganti rugi yang dijanjikan tidak terwujud).

\section{SKOR 7-10}

Rencana-rencana pengelolaan hutan disusun dengan pemahaman yang jelas terhadap isu-isu budaya masyarakat. Ada mekanisme transparan untuk menentukan isu-isu budaya penting yang mungkin dipengaruhi oleh pembalakan di kawasan tersebut, dengan mekanisme-mekanisme tambahan untuk memperbarui informasi dan untuk pemecahan konflik. Hanya sedikit bukti dalam masyarakat bahwa perusahaan beberapa kali melanggar rencana-rencana tersebut. 
I. 3.3.3 Tidak ada tanda-tanda tentang adanya perpecahan budaya

\section{SKOR 1-3}

Pencurian, pelacuran, perusakan yang semena-mena, dan kejahatan mungkin merupakan masalah-masalah yang serius. Anak-anak ditelantarkan atau ditinggalkan tanpa bimbingan. Penduduk mengemukakan kebingungan dan keraguannya terhadap nilai-nilai mereka sendiri atau mereka sama sekali tidak memilikinya. Tingkat stres tinggi, minat akan kehidupan rendah. Mungkin ada ketidakseimbangan jenis kelamin yang berat. Nilai-nilai budaya dan tradisional runtuh, atau kemungkinan digantikan oleh salah satu yang ditiru dari barat, atau kemungkinan diikuti dari televisi atau media lain; nilai-nilai budaya tidak diteruskan kepada generasi muda.

\section{SKOR 4-6}

Konflik antaretnis cukup banyak terjadi, dan rasio jenis kelamin agak tidak seimbang. Mungkin ada indikasi bahwa strategi pertahanan hidup secara tradisional tidak berfungsi sepenuhnya (mungkin sangat bergantung pada HPH). Acara-acara keagamaan dan perayaannya tetap berlangsung tetapi tidak seantusias dibandingkan sebelumnya.

\section{SKOR 7-10}

Sistem kepercayaan lokal tetap utuh dan berfungsi baik. Penduduk dari semua generasi mengemukakan perasaan bangga terhadap cara hidup mereka dan sistem nilai tradisionalnya. Acara-acara keagamaan tradisional tetap terlihat dan sistem ekonomi/subsisten tetap utuh atau menunjukkan peningkatan. 


\section{T Lembar Isian Induk $\mathrm{K} \& \mathrm{I}$}

Seri Perangkat K\&I CIFOR mencakup dua perangkat yang secara khusus membahas metode ilmiah sosial untuk menilai kesejahteraan manusia. Perangkat PPD dan PPPD, dirancang untuk para penilai yang memiliki tingkat keahlian yang beragam di bidang ilmu sosial, begitu juga Panduan Cara Pemberian Skor dan Analisis untuk Menilai Kesejahteraan Manusia. Dalam bagian ini, kami memandu para pengguna yang kurang berpengalaman dalam menggunakan komputer atau yang pengalaman ilmu sosialnya terbatas. Proses ini dimulai dengan menyiapkan lembar isian Excel yang digunakan untuk mengolah hasil observasi kuantitatif dan kualitatif secara sistematis, dalam kaitannya dengan K\&I sosial. Kami juga memberikan berbagai contoh bukti yang dapat Anda gunakan dalam mendukung penilaian kondisi manusia, dan cara-cara kondisi ini diberi skor oleh beberapa penilai di satu lokasi.

\section{LEMBAR ISIAN INDUK}

Lembar isian induk merupakan suatu mekanisme untuk mengelola berbagai macam data kualitatif (dan kuantitatif) secara sistematis dan akan muncul selama Anda melakukan penilaian kesejahteraan manusia. Lembar isian ini disebutkan berulang kali dalam PPD dan PPPD sebagai cara untuk membantu sistematisasi observasi Anda. Mulai dengan lembar isian ${ }^{11}$ Excel yang berisi daftar prinsip, kriteria dan indikator, Anda berangsur-angsur dapat

11 Tahap ini mungkin tidak disertai dengan contoh di komputer; contoh yang lebih sederhana saja yang diberikan. 
menambahkan informasi tentang berbagai contoh, kasus, bukti, dan bahan yang berhubungan dengan masing-masing isu ini.

Buatlah lembar isian induk seperti yang ditunjukkan dalam Gambar 1, yang menunjukkan semua prinsip, kriteria dan indikator sosial dalam daftar Anda (contoh: Acuan Generik K\&I CIFOR) dalam kolom pertama (A). Dengan menyisipkan baris-baris tambahan di antara isu-isu, Anda dapat memasukkan semua penjelasan dari bahan kasus, mulai dari Kolom B (bandingkan dengan Tabel 1), sambil Anda mengumpulkannya. Tabel 1 adalah versi yang disadur dari lembar isian induk yang berkaitan dengan keamanan akses antargenerasi terhadap sumber daya (Colfer dkk. 1996). Dalam ringkasan contoh ini, disajikan daftar kasus dari Suaka Margasatwa Danau Sentarum (SMDS) di Kalimantan Barat yang telah diberi skor. Untuk selanjutnya Anda mungkin ingin menyingkat kasus-kasus ini sehingga memudahkan presentasinya (seperti dalam Tabel 2 dari sumber yang sama).

Satu tambahan penting yang tidak tercantum dalam Tabel 1 adalah sumber informasi. Mungkin sumber 'pengamatan pribadi dalam suatu pernikahan', 'seorang pria Punan berumur 30 tahun dengan tingkat pendidikan sekolah', atau 'pembicaraan umum dalam suatu pertemuan wanita Iban'. Sumbersumber ini dapat dimasukkan di bawah masing-masing kasus, dimulai dari Kolom C. Sumber informasi ini dicantumkan karena dalam tahap selanjutnya Anda akan memerlukannya untuk mengevaluasi ketelitian dan potensi bias masing-masing bahan kasus atau bukti. Setelah menyusun berbagai jenis informasi, Anda akan menilai (memberikan skor) masing-masing kasus sesuai dengan kontribusinya terhadap kelestarian (berdasarkan pedoman pemberian skor pada bagian awal panduan ini). 
Segera setelah Anda menilai masing-masing kasus, maka Anda dapat merataratakan nilainya untuk masing-masing kasus, sehingga nilai suatu indikator dapat diperoleh. Waspadalah terhadap kasus-kasus yang Anda anggap penting atau menarik, yang mungkin memerlukan bobot lebih dalam penilaian. Anda dapat melakukan proses-proses yang sama untuk indikator - merata-ratakan nilainya untuk memperoleh nilai dari masing-masing kriteria; dan merata-ratakan kriteria untuk menghasilkan nilai dari masingmasing prinsip.

Anda dapat memperoleh semua skor rata-rata melalui tahap-tahap berikut:

1. Berikan nilai kelestarian dari contoh-contoh dan bahan kasus anda;

2. Tentukan skor untuk masing-masing kasus/contoh (sebagai bukti untuk indikator, seperti pada Tabel 2);

3. Rata-ratakan skor untuk masing-masing kriteria melalui skor yang dirataratakan untuk semua kasus di bawah kriteria;

4. Kalikan skor rata-rata dengan faktor bobot dalam K\&I sosial (contoh: 15\% untuk Kriteria 1.1 'Pihak pengelola lokal dapat secara efektif mengendalikan pemeliharaan dan akses terhadap sumber daya'); dan

5. Rata-ratakan nilai ini, tentukan untuk setiap kriteria, untuk memberikan suatu nilai pada prinsip (contoh: P. 1 diberi bobot 40\% pada K\&I sosial), dan akhirnya untuk seluruh set K\&I sosial.

Untuk mendapatkan skor untuk prinsip (1), 'Pengelolaan hutan menjaga atau meningkatkan akses antargenerasi terhadap sumber daya dan berbagai manfaat ekonomi secara adil', Anda dapat menerapkan rumus berikut: 
Skor (K. 1) x Bobot (K. 1) + Skor (K. 2) x Bobot (K. 2) + Skor (K. 3) x Bobot (K.3)

Di mana Bobot untuk K. 1, K. 2, dan K. 3 berturut-turut adalah 1,15; 0,15 dan 0,1 .

Secara keseluruhan, Kriteria dan Indikator untuk kesejahteraan manusia diklasifikasikan dalam tiga prinsip, dengan bobot sebagai berikut:

\begin{tabular}{|ll|}
\hline P. 1 & $\begin{array}{l}\text { PENGELOLAAN HUTAN MENJAGA ATAU MENINGKATKAN AKSES } \\
\text { ANTARGENERASI TERHADAP SUMBER DAYA DAN BERBAGAI } \\
\text { MANFAAT EKONOMI SECARA ADIL }(\mathrm{B} 1=40 \%)\end{array}$ \\
\hline P. 2 & $\begin{array}{l}\text { STAKEHOLDER YANG RELEVAN MEMILIKI HAK DAN } \\
\text { KEMAMPUAN YANG DIAKUI UNTUK MENGELOLA HUTAN SECARA } \\
\text { BERSAMA DAN ADIL (B } 2=30 \%)\end{array}$ \\
\hline $\begin{array}{l}\text { K. } 3 \\
\text { KESEHATAN HUTAN, PARA PENGELOLA HUTAN DAN BUDAYANYA }\end{array}$ \\
\hline
\end{tabular}

Untuk memberikan skor terhadap kesejahteraan manusia dalam kawasan yang Anda nilai, maka Anda dapat merata-ratakan skor yang telah diperoleh dengan rumus berikut:

Kesejahteraan manusia $=[\mathrm{P} .1$ (skor) $\mathrm{x}$ B 1] $+[\mathrm{P} .2$ (skor) $\mathrm{x}$ B 2] $]+[\mathrm{P} .3$ (skor) x B3].

Di mana P. 1 = Prinsip 1 dan B 1 = faktor bobot untuk prinsip itu.

Perlu diingat bahwa prosedur ini hanya merupakan cara untuk memudahkan pencatatan hasil pengamatan dan penilaian Anda secara sistematis. Prosedur 
ini membantu Anda untuk: mengingat apa yang telah Anda lihat; tetap terfokus pada kepentingan $\mathrm{K} \& \mathrm{I}$; dan mengidentifikasi kesenjangan pengetahuan yang Anda miliki sambil Anda melakukan proses penilaian. Nilai-nilai yang Anda hitung atau rata-ratakan bukan merupakan angka mati. Nilai-nilai ini sekedar menggambarkan penilaian kualitatif Anda, berdasarkan pengamatan secara sistematis tentang kondisi-kondisi masyarakat di suatu lokasi. Nilai-nilai yang diberikan adalah relatif dan tidak mutlak.

\section{Contoh Prinsip 2 dalam K\&I Sosial}

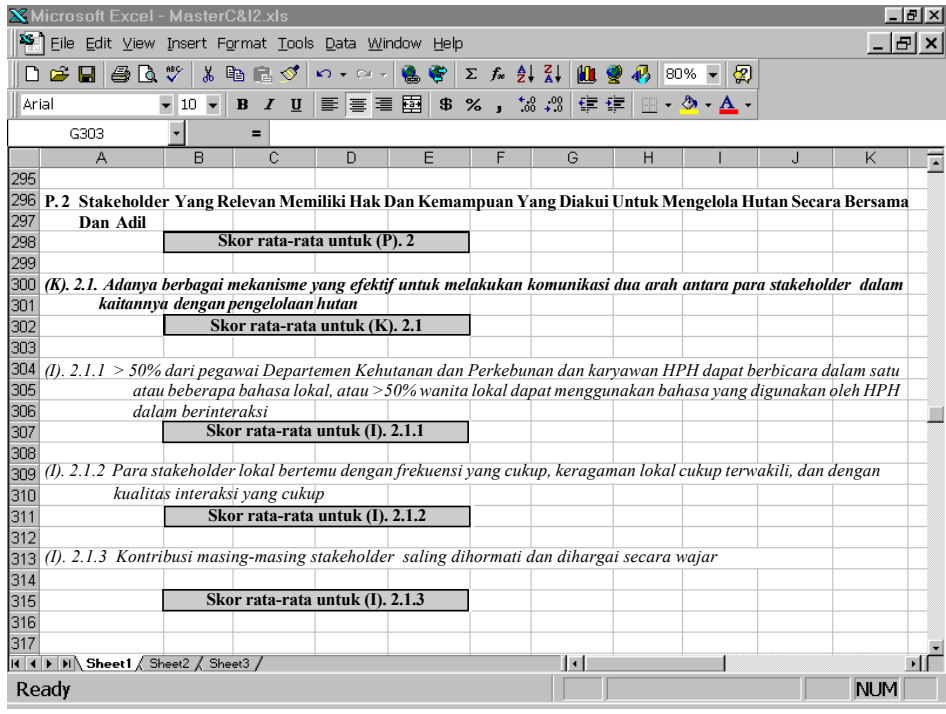

GAMBAR 1. Layar komputer menunjukkan bagian lembar isian induk K\&I. 
TABEL 1.

\section{Daftar sampel kasus (P. 1 'Pengelolaan hutan menjaga atau meningkatkan akses antargenerasi terhadap sumber daya dan berbagai manfaat ekonomi secara adil') dengan pemberian skor, dari Suaka Margasatwa Danau Sentarum, 1996.}

Dalam tabel ini (C) mengacu pada Colfer dan (W) pada Wadley. Masing-masing indikator diberi nomor secara berurut sesuai dengan masing-masing kriteria. Kasus yang diberi nomor disajikan di bawah masing-masing indikator. Colfer dan Wadley memberikan skor untuk masingmasing kasus. Meskipun Wadley melihat skor yang diberikan oleh Colfer sebelum ia melakukannya sendiri, Wadley berusaha memberikan skor menurut pendapatnya sendiri. Skorskor ini telah dirata-ratakan dengan Indikator dalam Tabel 2.

\section{(K) 1: PIHAK PENGELOLA LOKAL DAPAT SECARA EFEKTIF MENGENDALIKAN PEMELIHARAAN DAN AKSES TERHADAP SUMBER DAYA}

(I) 1.1 Kepemilikan dan hak pemanfaatan sumber daya (dalam satu generasi atau antargenerasi) jelas dan mengakui klaim yang sudah ada $^{12}$

1. Penduduk Ng. Kedebu, Bukit Rancong dan Danau Seluang memperoleh ijin dari 'kampung halamannya' masing-masing di Kapuas untuk menetap di Danau. Tidak satu pun dari tempattempat tersebut dihuni lebih dari beberapa dekade, dan kebanyakan penduduk dari ketiga masyarakat tersebut merupakan penduduk musiman. Di lain pihak, masing-masing masyarakat memiliki batas wilayah yang jelas dan ditetapkan secara adil, meskipun sifatnya tidak legal.

$\mathrm{C}=7 ; \mathrm{W}=7$ (Melayu)

12 Penekanan kami di sini adalah kepemilikan lokal dan hak guna lahan, tetapi kami mungkin menambahkan adanya perbedaan pendapat tentang hak sesungguhnya terhadap sumber daya. Penduduk lokal merasa bahwa sumber daya tersebut milik mereka, dan Pemerintah berpendapat sumber daya adalah milik Negara. 
2. Wong Garai telah kehilangan kontrol atas sebagian besar wilayah tradisional (lihat Gambar 4). Jumlah masyarakatnya yang kecil membuat mereka tidak harus memanfaatkan seluruh kawasan secara tetap, dan etika mereka yang dermawan membuat mereka membiarkan penduduk lain menempati lahan mereka di masa lampau. Pengurangan wilayah ini tidak disertai rasa permusuhan terhadap penduduk yang menempati lahan tersebut sekarang, yang umumnya adalah kerabat jauh mereka, atau secara historis berkerabat dengan penduduk Wong Garai.

$\mathrm{C}=5 ; \mathrm{W}=5$ (Iban)

3. Pada tahun 1989, Wong Garai berhasil menyelamatkan bagian hutan tua yang cukup signifikan dari kegiatan pembalakan. Kawasan Wong Garai terletak dalam konsesi PT Militer, tetapi penduduknya mengajukan permohonan kepada pemerintah daerah dan menerima bantuan berarti dari salah seorang yang merupakan anggota legislatif daerah pada saat itu. Hutan ini telah dinyatakan sebagai kawasan lindung oleh Bupati (lihat Colfer dan Wadley 1996).

$\mathrm{C}=7 ; \mathrm{W}=7$ (Iban)

4. Beberapa waktu lalu masyarakat Kelayang mengijinkan masyarakat Melayu menempati kembali lahan Kelayang. Sekarang masyarakat Melayu ingin mengklaimnya sebagai lahannya, termasuk mengajukan permohonan resmi kepada pegawai pemerintah daerah. Selama ini Kelayang berhasil mempertahankan lahannya. Masyarakat Melayu berada dalam wilayah yang batas-batasnya ditentukan berdasarkan batas administrasi modern di mana mereka tinggal, sedangkan masyarakat Iban tetap berpegang teguh pada sistem wilayah tradisionalnya (lokasi rumah panjang dan makam merupakan bukti dari hak-hak mereka). $\mathrm{C}=3 ; \mathrm{W}=3$ (Iban; Melayu)

5. Sejak tahun 1996, Bemban yang bekerjasama dengan masyarakat Iban dan kepala sukunya sebagai Bupati Badau, telah berhasil membujuk manajer sebuah perusahaan perkebunan dan HPH (keduanya dalam tahap perencanaan dan tahap pelaksanaan awal tahun 1993) untuk meninggalkan rencana mereka untuk bekerja di wilayah Bemban (sebagian karena 
alasan klaim lokal untuk mendapat ganti rugi ${ }^{13}$ yang berkaitan dengan pulau, hutan untuk makam yang dilindungi, dan tembawai, lokasi rumah panjang sebelumnya). $\mathrm{C}=6 ; \mathrm{W}=6$ (Iban)

6. Secara resmi Bemban ditetapkan sebagai bagian dari masyarakat Melayu di Pulau Duri pada tahun 1989. Sejak saat itu, Pulau Duri telah berusaha mengubah hak pemanfaatan atas lahan pertanian di kawasan tradisional Bamban yang diberikan secara cuma-cuma menjadi hak milik pribadi (menyewakan Pulau Duri untuk jangka panjang). Selama ini Bemban berhasil melawan usaha untuk merampas sebagian wilayah tradisionalnya. $\mathrm{C}=7$ (Iban); $\mathrm{C}=2 ; \mathrm{W}=2$ (Melayu)

\section{(I) 1.2 Berbagai aturan dan norma dalam penggunaan sumber daya dipantau dan ditegakkan ${ }^{14}$ pelaksanaannya}

1. Penduduk Ng. Kedebu menunjukkan 'kemarahan yang tepat' ketika masyarakat lain datang mengumpulkan rotan atau menangkap ikan di dalam wilayah mereka, bertentangan dengan aturan Ng. Kedebu.

$\mathrm{C}=7 ; \mathrm{W}=7$ (Melayu)

2. Masyarakat Bemban menemukan para pembalak tanpa ijin dalam wilayah mereka. Pada tanggal 1 Juli '96, semua pria ikut menyelidiki, pertama ke Pulau Duri (di mana kepala

13 Ganti rugi yang diajukan kemudian diberikan dalam jumlah Rp. 20 juta (sekitar 8500 dolar AS), atas dasar lenyapnya pohon buah-buahan, yang ditetapkan secara adat (hukum adat lokal).

${ }^{14}$ Penekanan kami pada peraturan dan kewajiban lokal. Tetapi ada banyak sekali peraturan dan kewajiban dari bagian yang berbeda di Departemen Kehutanan yang umumnya tidak dipantau dan ditegakkan (misalnya, pegawai kehutanan yang tidak mengetahui peraturan penebangan kayu atau yang seharusnya menegakkan peraturan; atau pegawai Proyek Konservasi yang mengelola SMDS tetapi secara tetap tidak menghiraukan burung Cangak merah dan Bangau storm yang diikat pada rakit orang Melayu, dan monyet ekor panjang dan burung-burung kecil tetap merupakan binatang peliharaan bagi penduduk Iban. 
kampung tinggal) dan kemudian ke kamp di dalam hutan, untuk menanyakan maksud para penebang kayu.

$\mathrm{C}=5 ; \mathrm{W}=5$ (Iban)

3. Sekelompok wanita muda Bemban dan anak-anak pergi ke tembawai (lokasi rumah panjang sebelumnya) untuk mengumpulkan paku-pakuan untuk makan malam. Mereka menjelaskan bahwa hanya panduduk dari masyarakat ini yang dapat mengumpulkan paku-pakuan di kawasan ini. Seorang anak perempuan mengambil nangka yang sedang dibawa oleh Colfer, dan mengatakan bahwa Colfer akan didenda karena telah mengambil buah nangka tersebut, tetapi gadis ini boleh mengambilnya (lihat Sandin 1980).

$\mathrm{C}=8 ; \mathrm{W}=8(\mathrm{Iban})$

4. Pada tahun 1994, penduduk Wong Garai melihat beberapa anggota rumah panjang lainnya mulai mengolah lahan hutan rawa dataran rendah Wong Garai. Meskipun penduduk anggota rumah panjang lainnya telah diberi lahan hutan rawa yang terbatas di masa lampau, beberapa orang berusaha memperluas lahannya tanpa ijin. Suatu pertemuan dilakukan di Wong Garai, dan suatu perselisihan besar bisa dihindari, orang-orang yang bermaksud memperluas lahan hutan rawanya menarik diri dari usaha ini (lihat Wadley 1997). Setelah itu, masyarakat Wong Garai telah mengungkapkan kebutuhan mereka dan hasratnya untuk melindungi hutan rawa dataran rendah mereka untuk dimanfaatkan sendiri di masa depan. ${ }^{15}$ $\mathrm{C}=9 ; \mathrm{W}=9$ (Iban)

5. Kadang selama awal 1990-an, penduduk Wong Garai telah dihubungi oleh orang luar untuk diijinkan mengumpulkan gaharu atau kayu beraroma harum (Aquilaria spp.) di hutan Wong Garai. Masyarakat Iban umumnya mengijinkan akses terhadap hutan mereka, kadang mereka juga ikut mencari kayu tersebut, dengan perjanjian mendapat imbalan (honor, membagi hasil, atau pembelian). Masyarakat juga sering merasa tertipu, dan saling mengeluh di antara mereka (jika sejumlah gaharu disembunyikan, atau bayaran tidak sesuai dengan pekerjaan). Meskipun sikap di sebagian masyarakat Iban terhadap orang luar ini dianggap

15 Salah satu pemicunya adalah karena ancaman transmigrasi ke dalam kawasan sungai yang rendah di Wong Garai - 200 kepala keluarga berasal dari Jawa. 
naif, sebenarnya masyarakat ini bersikap dermawan dan ramah, sehingga sulit sekali bagi mereka untuk menolak perminataan orang luar (lihat Peluso 1994, Colfer dkk. (1997), untuk pola yang mirip di antara masyarakat Dayak lainnya).

$\mathrm{C}=4 ; \mathrm{W}=4$ (Iban)

\section{(I) 1.3 Cara-cara untuk mengatasi konflik berfungsi baik tanpa menggunakan} kekerasan

1. Pada akhir tahun 1980 -an, terjadi konflik lahan antara Wong Garai dengan rumah panjang tetangganya. Selama tahun-tahun yang lampau, Wong Garai mengijinkan anggota masyarakat rumah panjang untuk berladang di kawasan Wong Garai, tetapi kemudian anggota masyarakat ini mengklaim lahan tersebut sebagai miliknya. Kasus ini muncul sebelum temenggong (kepala adat) mendengarnya, dan temenggong memutuskan bahwa kedua masyarakat yang terlibat konflik harus membagi lahan yang diperebutkan. Wong Garai menolak keputusan ini (secara lokal disetujui sebagai haknya), dengan alasan bahwa masyarakat rumah panjang lainnya tidak memiliki tembawai (lokasi rumah panjang tua) di kawasan Wong Garai yang diklaimnya. [Lihat juga (I)1.2, kasus 4].

$\mathrm{C}=8 ; \mathrm{W}=8($ Iban $)$

2. Penduduk Ng. Kedebu sering berselisih pendapat dengan PT Hutan Hebat, perusahaan kayu yang menarik kayu secara tetap dengan rakit melalui wilayah $\mathrm{Ng}$. Kedebu. Salah seorang anggota masyarakat bertugas sebagai pengemudi rakit perusahaan tersebut, dan juga sebagai seorang penengah tidak resmi dalam menyelesaikan perselisihan ini. Ada keluhan mengenai besarnya ganti rugi atas kerusakan alat penangkap ikan lokal yang ditimbulkan oleh rakit penarik kayu, tetapi sistem tampaknya berjalan baik.

$\mathrm{C}=8 ; \mathrm{W}=8$ (Melayu)

3. Pada tahun 1994, beberapa pedagang Iban menggunakan banyak pestisida komersial untuk memperoleh tangkapan ikan yang banyak untuk di jual ke Malaysia. Tindakan ini telah membantai ratusan ikan di keramba milik penduduk Ng. Kedebu (dan lainnya) yang di pelihara sebagai 'tabungan' di sepanjang Sungai Tawang. Masyarakat lokal sangat marah 
sehingga Proyek Konservasi, pegawai pemerintah pusat dan daerah, polisi dan tentara harus terlibat dalam menyelesaikan persengketaan ini. Akhirnya, seluruh masyarakat di dalam dan di sekitar SMDS menandatangani suatu perjanjian untuk tidak menggunakan racun dalam menangkap ikan.

$\mathrm{C}=4 ; \mathrm{W}=4$ (Melayu)

4. Penduduk Danau Seluang mengatakan bahwa dari tahun 1982-83, ketika masyarakat Iban tinggal di atas sungai Danau Seluang, mereka telah menggunakan racun untuk menangkap ikan sampai 11 kali. ${ }^{16}$ Setiap waktu panduduk mengeluh dan melaporkannya kepada yang berwewenang tetapi tidak ada tindakan. Hal ini akhirnya membuat masyarakat Danau Seluang yang sendiri melakukan peracunan ikan. Hal ini kembali mendesak pemerintah untuk mengambil tindakan, dan akibatnya peracunan ikan untuk sementara menurun.

$\mathrm{C}=6 ; \mathrm{W}=6$ (Iban, Melayu)

\section{(I) 1.4 Akses terhadap sumber daya dianggap adil oleh masyarakat lokal}

1. Di Ng. Kedebu, baru-baru ini kayu hasil pembalakan diambil secara diam-diam dari rakit kayu PT Hutan Hebat. Kayu-kayu ini digergaji menjadi papan dan digunakan untuk mendirikan masjid. Tindakan ini disetujui oleh anggota masyarakat dan dianggap adil karena perusahaan kayu telah mendapat untung banyak, dibandingkan dengan keuntungan yang dinikmati masyarakat lokal dari sumber daya lokal.

$\mathrm{C}=2 ; \mathrm{W}=2$ (Melayu)

2. Pada tahun 1992 (tahun terakhir yang paling kering) terjadi kebakaran hutan secara luas di kawasan Danau Seluang. Akibat kebakaran hutan ini ketersediaan rotan dan kayu sangat menurun, dan juga kerugian yang terkait dengan hilangnya sekitar 500 kayu tikung (sarang lebah), yang menyediakan sarang artifisial bagi lebah. Kebakaran ini sering dikatakan

16 Wadley menjelaskan bahwa mungkin ada perbedaan pandangan yang saling bertentangan tentang hak pemanfaatan tradisional, penduduk Iban kemungkinan menganggap sebagai hak mereka. Perbedaan pendapat serupa mungkin saja terjadi dalam banyak kasus seperti ini. 
sebagai tindakan yang disengaja dan berkaitan dengan rasa kecemburuan atau kemarahan masyarakat luar karena mereka tidak diijinkan untuk mengambil hasil hutan; atau memang karena sikap yang sembrono.

$\mathrm{C}=3 ; \mathrm{W}=3$ (Melayu)

3. Lihat juga (I) 1.2 , kasus 5 .

$\mathrm{C}=4 ; \mathrm{W}=4$ (Iban)

4. Di antara masyarakat Melayu, penggunaan jermal padat dianggap tidak adil. Jaring ini terlalu mahal dan besar, dan hanya orang-orang tertentu yang mampu membelinya. Selain itu, mereka menangkap ikan terlalu banyak, mengurangi jumlah ikan yang tersedia bagi para penangkap ikan lainnya yang hanya memiliki akses dengan teknik-teknik penangkapan ikan yang memerlukan banyak tenaga.

$\mathrm{C}=2 ; \mathrm{W}=2$ (Melayu)

\section{(I) 1.5 Masyarakat lokal merasakan keamanan aksesnya terhadap sumber daya}

1. Masyarakat Wong Garai membagi akses terhadap bagian hutan dan sungai tertentu dengan penduduk rumah panjang lainnya. Ada kekhawatiran bahwa hal ini akan mengarah kepada eksploitasi yang berlebihan, khususnya sumber daya perairan (misalnya, ikan). Penduduk juga khawatir terhadap kemampuan mengumpulkan ikan di Danau di masa depan selama musim kemarau - suatu kegiatan yang telah mereka lakukan selama paling sedikit 150 tahun dan memiliki hak tradisional - mengingat semakin banyak kehadiran masyarakat Melayu di kawasan yang secara tradisional telah dimanfaatkan oleh masyarakat Iban dan kemungkinan pemerintah akan mulai menegakkan batas-batas yang sangat berbeda di masa depan.

$\mathrm{C}=5 ; \mathrm{W}=5(\mathrm{Iban})$

2. Pada awal tahun 1994, kepala kampung Wong Garai menerima surat dari Bupati Lubok Rian, yang menerangkan bahwa akan ada orang-orang militer yang melalui kawasannya untuk melakukan proyek pemetaan secara luas untuk seluruh batas daerah. Kira-kira sebulan kemudian, para tentara datang ke kawasan Wong Garai, menurunkan tentara dengan 
helikopter di lokasi terbuka tidak jauh dari rumah panjang. Tentara tersebut tinggal beberapa hari di hutan, tetapi tidak pernah melakukan kontak dengan anggota rumah panjang. Masyarakat Wong Garai kecewa karena secara lokal dianggap sebagai pelanggaran tata krama. Mereka memandang bahwa ketidakpedulian tentara terhadap etiket ini sebagai suatu kesombongan dan sebagai wujud ketidakberdayaan masyarakat terhadap situasi ini.

$\mathrm{C}=4 ; \mathrm{W}=4$ (Iban)

3. Di seluruh kawasan SMDS, ada kekhawatiran bahwa kehadiran kelompok lain (misalnya, $\mathrm{HPH}$, kelompok etnis lain, transmigran) merambah wilayah yang dimanfaatkan secara tradisional, yang dapat mengancam kemampuan masyarakat untuk menggunakan sumbersumber alamnya di masa depan. Bagi masyarakat Iban, kekhawatiran ini khususnya menyangkut sumber daya hutan mereka; sebaliknya masyarakat Melayu khawatir tentang sumber daya perairan.

$\mathrm{C}=4 ; \mathrm{W}=4$ (Iban; Melayu)

4. Masyarakat di Bemban, Ng. Kedebu dan Kelayang menunjukkan keyakinan mereka bahwa mereka mempunyai hak yang diakui/sah terhadap kawasan dan sumber daya yang mereka gunakan - meskipun kehadiran stakeholder lain (khususnya Proyek Konservasi dan HPH) saling berlomba untuk mendapatkan sumber daya ini.

$\mathrm{C}=8 ; \mathrm{W}=8$ (Iban; Melayu)

(K) 2: Para pengelola hutan memperoleh manfaat ekonomi yang cukup dari hasilhasil hutan yang diambilnya

\section{(I) 2.1 Mekanisme distribusi manfaat dianggap adil oleh masyarakat lokal}

1. Masyarakat di Ng. Kedebu dan Bukit Rancong merasa bahwa distribusi dana yang tersedia untuk Proyek Konservasi dari ekowisata dan pembayaran upah dan bantuan lainnya dari proyek tidak merata.

$\mathrm{C}=2 ; \mathrm{W}=2$ (Melayu) 
2. Pemberian royalti untuk masyarakat lokal, untuk mengakui hak mereka yang sudah ada, telah diusulkan dengan beberapa mekanisme pembagian manfaat yang lebih adil. Tidak ada royalti yang dibayarkan kepada masyarakat SMDS atau di sekitarnya. Berbagai pajak dibayar oleh perusahaan untuk lembaga kehutanan di Kapuas, tetapi hasilnya dikirim ke Pontianak (dan sebagiannya lagi dikirimkan ke Jakarta, bandingkan dengan Ascher 1993).

$\mathrm{C}=2 ; \mathrm{W}=2$ (Melayu)

3. Pemerintah Indonesia menginginkan pelaksanaan 'HPH Bina Desa', atau suatu program 'panduan desa'. Program ini dirancang untuk diterapkan secara partisipatif, dan meliputi proyek-proyek yang menghasilkan pendapatan, perbaikan desa secara struktural, peningkatan pertanian, dan bermanfaat untuk pendidikan, agama, atau layanan masyarakat lainnya (bandingkan dengan Wentzel 1995). PT Panggau Libau (sebagian dimiliki oleh orang Iban lokal - suatu situasi yang unik dalam pengalaman kami) memberikan daftar gereja dan sekolah yang telah mereka bangun, upah guru yang telah dibayar, dsb. Namun demikian, ada juga banyak keluhan tentang kegiatan perusahaan, dari Kelayang (lihat di atas; dan hasil penelitian Wadley sebelumnya dan juga mengenai masyarakat lain). Kebanyakan penduduk yang diwawancarai di seluruh kawasan lindung dan sekitarnya menyatakan bahwa mereka belum pernah mendengar tentang HPH Bina Desa; tanggapan dari beberapa penduduk telah mengetahuinya (salah satunya pegawai daerah, seorang pegawai HPH) menjelaskan bahwa kegiatan program ini sedikit sekali.

$\mathrm{C}=4 ; \mathrm{W}=4$ (Iban; Melayu)

\section{(I) 2.2 Adanya kesempatan bagi masyarakat lokal dan masyarakat yang menggantungkan hidupnya pada hutan untuk memperoleh pekerjaan dari perusahaan-perusahaan kehutanan}

1. Sedikit sekali warga masyarakat sekitar SMDS yang bekerja untuk HPH. Kebanyakan para pekerja berasal dari luar. Kelayang berada di dalam kawasan HPH PT Panggau Libau, sebagian dimiliki oleh orang Iban dari kawasan Lubok Rian, yang beberapa di antaranya berkerabat dengan penduduk Kelayang. Meskipun keterlibatan ekonomi Kelayang dengan HPH lebih besar dibandingkan dengan keterlibatan mereka dengan HPH lainnya (misalnya, 
PT Militer atau PT Hutan Hebat) dan masyarakat lokal, masih ada konflik yang muncul kembali (lihat Colfer dan Wadley 1996). Konflik ini timbul karena adanya perbedaan persepsi tentang kesempatan bekerja yang tidak memadai, biaya sewa lahan yang dijanjikan tetapi tidak dibayar, meminta rotan tetapi kemudian tidak dibayar, dan ganti rugi yang tidak adil ketika anggota masyarakat tewas oleh perahu perusahaan.

$\mathrm{C}=3 ; \mathrm{W}=3$ (Iban)

2. Di Ng. Kedebu, hanya satu orang yang memiliki hubungan kerja jangka panjang dengan perusahaan HPH. Pekerja pria sering bekerja sementara untuk HPH, tetapi menurut persepsi beberapa orang, jika hasil perikanan baik, maka mereka akan meninggalkan pekerjaan di HPH. Ini berarti bahwa penghasilan dari perikanan (dan usaha ekonomi yang terkait) lebih baik daripada penghasilan di HPH.

$\mathrm{C}=2 ; \mathrm{W}=2$ (Melayu)

3. Lihat juga (I) 2.3, kasus 1 .

$\mathrm{C}=2 ; \mathrm{W}=2$ (Melayu)

\section{(I) 2.3 Upah dan tunjangan lainnya sesuai dengan standar nasional dan/atau ILO}

1. Para pekerja yang berbincang dengan Colfer - campuran penduduk lokal dan pendatang baru - menganggap upah yamg mereka terima cukup baik, dengan tunjangan yang cukup baik, dan kondisi pekerjaan serta standar keselamatan kerja yang cukup baik. ${ }^{17}$ Di pihak lain, Wadley menemukan bahwa penduduk Iban yang bekerja untuk HPH Indonesia umumnya mengeluh tentang upah lokal mereka yang rendah (dibandingkan dengan upah yang mereka dapatkan untuk pekerjaan serupa di Malaysia), kondisi kerja dan peralatannya berbahaya dan buruk. Hanya sedikit masyarakat Wong Garai yang bekerja untuk PT Panggau

${ }^{17}$ Seperti persepsi keamanan tentang kepemilikan, pekerja lokal mungkin memiliki pendapat yang berbeda dibandingkan dengan penilai dari tempat lain. Misalnya, kondisi kerja lokal tidak sesuai dengan kondisi yang diusulkan oleh tim CIFOR sebelumnya, atau dengan standar ILO. 
Libau dan mengatakan bahwa mereka tidak pernah dibayar dan tidak akan bekerja lagi di perusahaan ini.

$\mathrm{C}=2 ; \mathrm{W}=2$ (Iban)

\section{(I) 2.4 Ganti rugi terhadap kerusakan diberikan secara adil}

1. Pada tahun 1992, sebuah subkontraktor PT Militer/PT Hutan Hebat memberikan sebuah generator $500 \mathrm{w}$ kepada Bemban sebagai ganti rugi hak untuk menebang hutan yang luasnya tidak diketahui di dalam sejumlah kawasan tradisional Bemban. Penduduk menjadi lebih cermat, meskipun mereka masih tidak memiliki kekuasaan untuk menyuarakan kehendak mereka untuk meminta keadilan.

$\mathrm{C}=2 ; \mathrm{W}=2(\mathrm{Iban})$

(K) 3: Masyarakat mengaitkan masa depan mereka dan anak-anak mereka dengan pengelolaan sumber daya hutan

(I) 3.1 Masyarakat menanamkan modal di lingkungannya (misalnya, waktu, tenaga, uang)

1. Ada sejumlah sekolah dan masjid-masjid yang baru dibangun di kawasan SMDS.

$\mathrm{C}=10 ; \mathrm{W}=10$ (Melayu)

2. Penegakan berbagai aturan lokal untuk melindungi sumber daya. Bagi masyarakat Melayu, ini meliputi perlindungan kawasan khusus seperti benih ikan; larangan untuk menangkap ikan yang lebih kecil dari ukuran mata jaring dan di bawah ukuran tertentu; melarang akses terhadap rotan dan kayu yang berharga; pembakaran ilegal; dan bagi masyarakat Iban, pemeliharaan hutan lindung (pulau) khusus dan lokasi rumah panjang (tembawai), dan larangan bertani di puncak gunung sehingga regenerasi hutan bisa berlangsung untuk swidden (lihat Wadley dkk. 1996).

$\mathrm{C}=10 ; \mathrm{W}=10 ; \mathrm{C}=8$ (Melayu) 
3. Tingkat pendidikan terus meningkat (dengan pengorbanan/investasi yang cukup besar oleh orang tua dan anak-anak). Konsekuensi negatif keadaan ini juga cukup besar dan diakui, misalnya kehilangan pengetahuan ritual dan lingkungan, mengurangi nilai pekerjaan dan pengetahuan tradisional, dan peningkatan konsumerisme.

$\mathrm{C}=6 ; \mathrm{W}=6($ Iban; Melayu $)$

\section{(I) 3.2 Tingkat migrasi keluar rendah}

1. Ada migrasi musiman yang masuk ke dalam Kawasan Lindung, terutama dari penduduk di sepanjang Sungai Kapuas yang masih ada hubungan kekeluargaan dengan masyarakat di Kawasan Lindung. Ikatan perkonomian dan kekeluargaan yang dekat antara masyarakat Kawasan Lindung dengan masyarakat 'kampung halamannya' di sepanjang Sungai Kapuas akan menyulitkan pengendalian peningkatan populasi musiman. Masyarakat yang semua adalah nelayan musiman di Kawasan Lindung kemudian menetap di dalam kawasan dan mendirikan rumah tetap di sana. Banyak penduduk yang juga menyatakan ingin menetap dan membentuk masyarakat yang lebih baik untuk kepentingan anak-anak mereka.

$\mathrm{C}=5 ; \mathrm{W}=5$ (Melayu)

2. Pria Iban secara tetap merupakan tenaga kerja migran di Malaysia, di mana mereka bekerja untuk memperoleh upah yang lebih tinggi di sana. Umumnya mereka kembali ke rumah, membawa penghasilan tambahan (sering pada saat panen).

$\mathrm{C}=5 ; \mathrm{W}=5$ (Iban)

3. Migrasi keluar untuk menetap tidak umum. Ada banyak contoh para pemuda pergi meninggalkan kampungnya untuk bersekolah dan kembali lagi setelah selesai; dan penduduk setengah baya umumnya pergi bekerja untuk sementara waktu tetapi kembali untuk mempraktekkan kemampuan dan pengalaman barunya di kampung mereka.

$\mathrm{C}=7 ; \mathrm{W}=7$ (Iban; Melayu) 


\section{(I) 3.3 Masyarakat menyadari pentingnya keseimbangan antara jumlah} penduduk dengan pemanfaatan sumber daya alam

1. Pengendalian jumlah kelahiran telah diterima secara luas-sering dikaitkan dengan isuisu pemanfaatan sumber daya. Bagi para wanita Iban, mereka mengakui bahwa keluarga lebih mampu mecukupi kebutuhan jika jumlah anaknya sedikit, bahwa mereka bebas dari risiko kematian selama kehamilan dan melahirkan, dan mereka dapat lebih produktif secara ekonomis, tetapi tetap khawatir jika tingkat kesuburan rendah atau penduduk aslinya stabil, maka bisa dijadikan alasan untuk memasukkan transmigran ke daerah mereka, yang jumlahnya jauh lebih banyak daripada jumlah mereka sendiri.

$\mathrm{C}=7 ; \mathrm{W}=7$ (Iban)

2. Migrasi masuk cukup banyak, tanpa ada cara-cara untuk mengendalikannya. Bahkan sikap keramah-tamahan mereka mungkin membuat pengendalian menjadi lebih sulit tanpa dukungan dari luar.

$\mathrm{C}=3 ; \mathrm{W}=3$ (Melayu)

3. Lihat juga (I) 3.2.

\section{(I) 3.4 Anak-anak mendapatkan pendidikan (formal dan informal) tentang} pengelolaan sumber daya alam

1. Orang tua memilih bidang pendidikan yang berbeda-beda untuk dijalani oleh anak-anak mereka (dalam satu keluarga) dengan harapan bahwa jika anak-anak kembali ke rumah, banyak pengetahuan dapat diterapkan untuk keluarga dan masyarakat di mana mereka berasal. Kami menemukan sejumlah contoh para pemuda melakukan hal ini.

$\mathrm{C}=5 ; \mathrm{W}=5($ Iban $)$

2. Sifat kepemilikan/hak atas pohon oleh masyarakat Iban dan berbagai ritusnya masih berlangsung (lihat Wadley 1997), dan mereka tetap memelihara ritual yang berkaitan dengan pertanian. Namun mereka khawatir bahwa 'cara-cara kuno'- ritual nyanyian, bahas a daerah, 
dan pengetahuan tentang pertanian dan hutan - akan lenyap di antara para pemuda. Persaingan antara pendidikan nasional dan televisi tetap berlangsung. Pada bulan Juni 1996, misalnya, ritual rumah panjang yang penting diadakan pada pukul satu dini hari (memberikan persembahan, nyanyian kepada dewa-dewa), pada saat yang sama, para pemuda memutar musik pop Indonesia dari tape dengan volume tinggi dan berdisko di salah satu ujung rumah panjang. Sumber budaya dan pengetahuan lingkungan (yang merupakan bagian integral pengelolaan lestari) yang telah dimiliki oleh nenek moyang mereka akan segera lenyap.

$\mathrm{C}=4 ; \mathrm{W}=5$ (Iban)

\section{(I) 3.5 Perusakan sumber daya alam oleh masyarakat lokal jarang terjadi ${ }^{18}$}

1. Peracunan ikan berulang, secara luas oleh kelompok kecil pedagang Iban, tetapi juga oleh beberapa penduduk Melayu.

$\mathrm{C}=4 ; \mathrm{W}=4$ (Iban; Melayu)

2. Penggunaan jermal padat, oleh beberapa orang Melayu yang kaya (di bawah kebijakan pemerintah yang tidak seimbang).

$\mathrm{C}=3 ; \mathrm{W}=3$ (Melayu)

3. Persepsi bahwa hutan rawa dipanen secara berlebihan oleh penduduk lokal - persediaan jenis yang ada saat ini untuk penduduk lokal sangat berkurang (tembesu', kawi, kelansau, medang, menyawai). [Kebanyakan jenis yang dimanfaatkan oleh masyarakat Melayu adalah jenis dari rawa]

$\mathrm{C}=5 ; \mathrm{W}=5$ (Melayu)

${ }^{18} \mathrm{~K} \&$ I lainnya akan membahas kerusakan yang disebabkan oleh stakeholder lainnya (misalnya, penebangan kayu oleh HPH tanpa menghiraukan peraturan yang ada; transmigrasi dengan jumlah keluarga yang cukup besar ke kawasan hutan yang telah dihuni oleh kelompok lain; konversi kawasan hutan alam menjadi hutan tanaman industri atau perkebunan kelapa sawit/karet). 


\section{(I) 3.6 Masyarakat memelihara hubungan batin dengan lahan hutan}

1. Selama Colfer tinggal di Kelayang, tiga jenis perayaan - yang terkait dengan pemanfaatan sumber daya alam diteliti, yang semuanya melibatkan para pemuda secara aktif (salah satunya 'memberi sesajen' untuk roh buaya yang lapar di sungai yang tampak dalam mimpi anggota masyarakat; 'memberi sesajen' untuk tanah sebelum mulai memanen padi; dan 'memberi sesajen' untuk tanah selama masa persiapan penanaman).

$\mathrm{C}=10 ; \mathrm{W}=10$ (Iban)

2. Perasaan kuat terhadap sejarah dan tempat (di antara masyarakat Iban) dan mengakui tanggung jawab untuk menyediakan kebutuhan untuk anak-anak, cucu dan keturunannya.

$\mathrm{C}=8 ; \mathrm{W}=8$ (Iban)

3. Masyarakat Iban menyebut hutan sebagai seput menoa ('nafas lahan'), dan mengakui konsekuensi fungsi-fungsi hidrologis hutan jika terlalu banyak hutan yang ditebang misalnya, sumber-sumber air ${ }^{19}$ yang kering (lihat Wadley dkk. 1996).

$\mathrm{C}=8 ; \mathrm{W}=8$ (Iban)

4. Para orang tua di Ng. Kedebu menunjukkan tanggung jawabnya terhadap keturunan mereka, termasuk kepedulian terhadap kelestarian sumber alam yang penting untuk kehidupan mereka (kayu, ikan, rotan, lebah).

$\mathrm{C}=5 ; \mathrm{W}=5$ (Melayu)

19 Pengetahuan hidrologi ini memiliki komponen kekuatan spiritual bagi masyarakat Iban yang berkeyakinan bahwa jika mereka tidak memelihara lahan secara ekologis dan secara ritual, mereka akan terancam oleh 'panas' magis (angat) yang tercermin dalam kesehatan penduduk dan gangguan sosial. 
TABEL 2.

Pemberian skor K\&I untuk Keamanan Akses Antargenerasi terhadap Sumber Daya* (Colfer, Wadley dan Harwell)

\begin{tabular}{|c|c|c|c|c|c|c|c|c|c|}
\hline \multirow{2}{*}{ Kasus/Bukti } & \multicolumn{4}{|c|}{ Iban } & \multicolumn{4}{|c|}{ Melayu } & \multirow[b]{2}{*}{ L.R } \\
\hline & $\mathrm{C}$ & $\mathrm{W}$ & $\mathrm{H}^{7}$ & $\mathrm{R}$ & $\mathrm{C}$ & $\mathrm{W}$ & $\mathrm{H}$ & $\mathrm{R}$ & \\
\hline \multicolumn{10}{|c|}{$\begin{array}{l}\text { (K) 1: Pihak pengelola lokal dapat secara efektif mengendalikan pemeliharaan dan akses } \\
\text { terhadap sumber daya }\end{array}$} \\
\hline $\begin{array}{l}\text { (I) } 1.1 \text { Kepemilikan dan hak untuk } \\
\text { menggunakan sumber daya (dalam } \\
\text { satu generasi atau antargenerasi) } \\
\text { jelas dan mengakui klaim yang sudah } \\
\text { ada }^{1}\end{array}$ & 5,60 & 5,25 & 8,00 & 6,28 & 4,00 & 4,00 & 4,00 & 4,00 & 5,30 \\
\hline $\begin{array}{l}\text { (I) } 1.2 \text { Berbagai aturan dan norma } \\
\text { dalam penggunaan sumber daya } \\
\text { dipantau dan ditegakkan pelak- } \\
\text { sanaannya }^{2}\end{array}$ & 6,50 & 6,50 & 7,50 & 6,83 & 5,50 & 5,50 & 4,50 & 5,17 & 6,12 \\
\hline $\begin{array}{l}\text { (I) } 1.3 \text { Cara-cara untuk mengatasi } \\
\text { konflik berfungsi baik tanpa } \\
\text { menggunakankekerasan }\end{array}$ & 6,00 & 6,00 & 8,00 & 6,67 & 5,00 & 5,00 & 4,00 & 4,67 & 5,81 \\
\hline $\begin{array}{l}\text { (I) } 1.4 \text { Akses terhadap sumber daya } \\
\text { dianggap adil oleh masyarakat lokal }\end{array}$ & 4,00 & 4,00 & 5,00 & 4,33 & 2,33 & 2,33 & 3,00 & 2,56 & 3,57 \\
\hline $\begin{array}{l}\text { (I) } 1.5 \text { Masyarakat lokal merasakan } \\
\text { keamanan aksesnya terhadap sumber } \\
\text { daya }^{3}\end{array}$ & 5,25 & 5,25 & 4,00 & 4,83 & 6,00 & 6,00 & 4,00 & 5,33 & 5,05 \\
\hline \multicolumn{10}{|c|}{$\begin{array}{l}\text { (K) 2: Para pengelola hutan memperoleh manfaat ekonomi yang cukup dari hasil-hasil hutan } \\
\text { yang diambilnya }\end{array}$} \\
\hline $\begin{array}{l}\text { (I) } 2.1 \text { Mekanisme distribusi manfaat } \\
\text { dianggap adil oleh masyarakat lokal }{ }^{4}\end{array}$ & 4,00 & 4,00 & 2,00 & 3,33 & 2,67 & 2,67 & 2,00 & 2,44 & 2,95 \\
\hline $\begin{array}{l}\text { (I) } 2.2 \text { Adanya kesempatan bagi } \\
\text { masyarakat lokal dan masyarakat } \\
\text { yang menggantungkan hidupnya } \\
\text { pada hutan untuk memperoleh } \\
\text { pekerjaan dari perusahaan-perusa- } \\
\text { haankehutanan }{ }^{4}\end{array}$ & 3,00 & 3,00 & 2,00 & 2,67 & 2,00 & 2,00 & 2,00 & 2,00 & 2,38 \\
\hline
\end{tabular}




\begin{tabular}{|c|c|c|c|c|c|c|c|c|c|}
\hline $\begin{array}{l}\text { (I) } 2.3 \text { Upah dan tunjangan lainnya } \\
\text { sesuai dengan standar nasional } \\
\text { dan/atau ILO }\end{array}$ & 2,00 & 2,00 & 3,00 & 2,33 & & & 3,00 & 3,00 & 2,47 \\
\hline $\begin{array}{l}\text { (I) } 2.4 \text { Ganti rugi terhadap kerusakan } \\
\text { diberikan secara adil }{ }^{6}\end{array}$ & 3,50 & 3,50 & 3,00 & 3,33 & & & 3,00 & 3,00 & 3,27 \\
\hline \multicolumn{10}{|c|}{$\begin{array}{l}\text { (K) 3: Masyarakat mengaitkan masa depan mereka dan anak-anak mereka dengan pengelolaan } \\
\text { sumber daya hutan }\end{array}$} \\
\hline $\begin{array}{l}\text { (I) } 3.1 \text { Masyarakat menanamkan } \\
\text { modal di lingkungannya (misalnya, } \\
\text { waktu, tenaga, uang) }{ }^{4}\end{array}$ & 8,00 & 8,00 & 8,00 & 8,00 & 8,00 & 8,67 & 4,00 & 6,89 & 7,52 \\
\hline $\begin{array}{l}\text { (I) } 3.3 \text { Masyarakat menyadari } \\
\text { pentingnya keseimbangan antara } \\
\text { jumlah penduduk dengan peman- } \\
\text { faatan sumber daya alam } 4\end{array}$ & 6,33 & 6,33 & 7,00 & 6,56 & 5,00 & 5,00 & 2,50 & 4,17 & 5,53 \\
\hline $\begin{array}{l}\text { (I) } 3.4 \text { Anak-anak mendapatkan } \\
\text { pendidikan (formal dan informal) } \\
\text { tentang pengelolaan sumber daya } \\
\text { alam }^{5}\end{array}$ & 6,00 & 6,00 & 4,00 & 5,34 & & & 4,00 & 4,00 & 5,00 \\
\hline $\begin{array}{l}\text { (I) } 3.5 \text { Perusakan sumber daya alam } \\
\text { oleh masyarakat lokal jarang terjadi }{ }^{4}\end{array}$ & 4,00 & 4,00 & 5,00 & 4,33 & 4,00 & 4,00 & 5,00 & 4,33 & 4,33 \\
\hline $\begin{array}{l}\text { (I) } 3.6 \text { Masyarakat memelihara } \\
\text { hubungan batin dengan lahan hutan }\end{array}$ & 8,67 & 8,67 & 9,00 & 8,78 & 5,00 & 5,00 & 3,00 & 4,33 & 6,87 \\
\hline
\end{tabular}

\section{Keterangan:}

$\mathrm{C}=$ Colfer, $\mathrm{W}=$ Wadley, $\mathrm{H}=$ Harwell, $\mathrm{R}=$ Rata-rata, $\mathrm{L} \cdot \mathrm{R}=$ Luas Rata-rata. 
* Susunan kata mungkin sangat berbeda karena pengujian lapangan dilaksanakan pada tahun 1996; dan ringkasan dan rata-rata beberapa indikator dalam tabel sebelumnya tidak akan memberikan rata-rata yang sama, sebab kami mengganti rujukan kasus yang ada dalam kotak teks asli Colfer dan Wadley.

1 Berdasarkan skor rata-rata (Colfer, Wadley) untuk 6 kasus (lihat Tabel 1).

2 Berdasarkan skor rata-rata (Colfer, Wadley) untuk 5 kasus (lihat Tabel 1).

3 Berdasarkan skor rata-rata (Colfer, Wadley) untuk 4 kasus (lihat Tabel 1).

4 Berdasarkan skor rata-rata (Colfer, Wadley) untuk 3 kasus (lihat Tabel 1).

5 Berdasarkan skor rata-rata (Colfer, Wadley) untuk 2 kasus (lihat Tabel 1).

6 Berdasarkan skor rata-rata (Colfer, Wadley) untuk 1 kasus (lihat Tabel 1).

7 Harwell memberikan skor kriteria dan indikator, tetapi kasusnya tidak.

Fakta bahwa hutan di dalam dan di sekitar SMDS termasuk dalam keadaan yang baik berarti skornya tinggi, pada skala global. Skor rata-rata yang rendah untuk kriteria 2 (2.5) kemungkinan dianggap sebagai flashpoint; dan tentu saja kesadaran akan ketidakadilan pembagian manfaat hutan di kalangan penduduk lokal (mereka merasa bahwa seluruh manfaat adalah milik mereka) merupakan keluhan yang sering timbul dan alasan terjadinya konfrontasi yang melibatkan kekerasan. Penilaian kami tentang kekuatan perasaan aman mengenai akses terhadap sumber daya (7) secara komperatif tinggi dan hubungan konsep kesejahteraan yang jelas di antara mereka dan anak-anak mereka dan hutannya (5.4) tampaknya memberikan kontribusi terhadap kelestarian dengan cara; a) memastikan 'kepentingan' mereka terhadap hutan, dan b) memberikan motivasi untuk menghindari seluruh perusakan potensial di dalam kawasan. 


\section{W Panduan Analisis Kuantitatif}

Panduan Analisis Kuantitatif dirancang untuk membantu para pengguna yang tertarik untuk menganalisis data yang diperoleh dari metode kuantitatif yang tersedia dalam Panduan Penilaian Dasar Kesejahteraan Manusia dan Panduan Pendamping Penilaian Dasar Kesejahteraan Manusia. Pada bagian ini, kami menyediakan panduan terinci bagi para pengguna tentang penggunaan lembar isian dengan program komputer, analisis data deskriptif yang sederhana, dan beberapa uji statistik yang lebih rumit. Mengingat tingkat ketrampilan yang berbeda dalam hal pengoperasian komputer yang telah kami lakukan melalui berbagai pengujian metode penilaian terhadap K\&I sosial, kami berkesimpulan bahwa 'mulai dengan sesuatu yang sederhana' merupakan cara yang paling aman. Jika Anda sudah biasa bekerja dengan dengan lembar isian komputer, Anda mungkin dapat melewati sebagian besar pembahasan yang diberikan berikut ini. Namun demikian, jika Anda seorang pengguna komputer yang relatif baru, kami berharap petunjuk-petunjuk berikut ini dapat membantu Anda.

\section{A. ANALISIS HASIL DARI METODE IDENTIFIKASI STAKEHOLDER (CATPAC)}

CatPac adalah sebuah paket piranti lunak yang menggunakan analisis jaringan neural untuk mengidentifikasi gerombolan cara bicara manusia. Kebanyakan para pakar komunikasi melihat cara berbicara manusia untuk mencerminkan pikiran manusia. CatPac telah digunakan dalam konteks penilaian kesejahteraan manusia di hutan, untuk mengidentifikasi 
stakeholder yang relevan di hutan-hutan di Kamerun, Indonesia dan Brasil. Instruksi penggunaan metode ini tersedia dalam PPPD. Panduan ini hanya menguraikan analisis hasil-hasil ini.

\section{PANDUAN PENGGUNAAN CATPAC ${ }^{20}$}

Bagi para pengguna Catpac yang baru, bagian ini menjelaskan bagaimana cara memasukkan teks, di mana beberapa jaringan perangkat komputer perlu diinstal, dan bagimana membuat dendogram dan peta kognitif yang terdiri dari hasil-hasil Catpac.

\section{a. Cara memasukkan teks}

- Setelah Anda mencatat hasil wawancara, tahap berikutnya adalah memasukkan teks. Anda dapat memasukkan teks dengan menggunakan berbagai piranti lunak word processing, tetapi ingat untuk menekan Enter pada setiap akhir baris. Ini untuk menjaga agar teks tetap dalam format ${ }^{21}$ yang dapat dibaca saat Anda membuka teks dengan menggunakan piranti lunak CatPac.

- Setelah Anda selesai memasukkan teks bagian pertama, ketiklah a '-1' sebagai pemisah antara peserta yang berbeda. Jangan lupa untuk

20 Ada Panduan Pengguna CatPac oleh Woelfel (1998). Panduan ini berisi informasi yang lebih luas untuk piranti lunak ini. Tujuan panduan kami adalah untuk memberikan prosedur yang paling penting dalam menjalankan CatPac.

${ }^{21}$ Banyak kolaborator kami menemukan bahwa teks yang telah dimasukkan kemudian menjadi satu baris yang panjang ketika mereka membuka file teks pada piranti lunak CatPac. Ini terjadi karena mereka tidak menekan Enter pada setiap akhir baris. 
memasukkan data dari satu kategori (pria/wanita, kelompok-kelompok etnis yang berbeda, pekerjaan, dll) dalam satu file.

- Simpan file dalam format teks (*.txt). CatPac hanya dapat membuka file-file teks.

\section{b. Cara memilih metode penggerombolan yang sesuai}

Semua teknik penggerombolan yang disajikan dalam CatPac didasarkan atas sebuah metode pengelompokan. Tidak ada aturan yang pasti untuk memilihnya. Untuk mengetahui lebih lanjut tentang kelebihan dan kelemahan masing-masing metode, Anda dapat menuju menu Opption, dan kemudian memilih metode clustering. Anda akan dituntun oleh dialog menu.

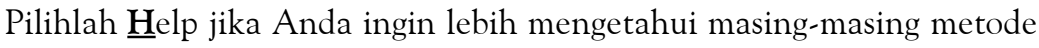
clustering.

\section{c. Cara membuat file exclude}

Karena Anda tertarik dalam penggerombolan kata-kata/konsep yang signifikan, Anda mungkin ingin memisahkan kalimat tertentu atau katakata lain dari analisis Anda (seperti 'adalah', 'sangat', 'itu'). CatPac memiliki file exclude ${ }^{22}$ dalam bahasa Inggris. Dalam banyak kasus file ini tidak banyak membantu Anda, karena kebanyakan wawancara harus dilakukan dalam bahasa daerah. Dalam kasus ini, Anda perlu membuat file exclude dalam bahasa tersebut. Sebagai langkah pertama, Anda dapat menerjemahkan file bahasa Inggris dan gunakan terjemahannya sebagai file exclude yang baru.

22 Sebuah file yang berisi daftar kalimat yang muncul dalam teks wawancara Anda dan tidak memiliki arti khusus, dan tidak banyak berarti dalam menyumbangkan pemahaman terhadap konsep-konsep yang berkaitan dengan studi. 
Mungkin lebih mudah untuk membayangkan tanda-tanda tata bahasa dari bahasa daerah dan mendaftarkannya dalam file exclude. Anda dapat melakukannya dengan mengeluarkan file versi Inggris, menerjemahkan baris demi baris ke dalam bahasa daerah dan kemudian menyimpannya dalam file lain dengan keterangan tambahan *. exc. Jika Anda menemukan kalimatkalimat yang tidak relevan dan perlu dikeluarkan, Anda dapat menambahkannya pada daftar, dengan melampirkannya di bawah file exclude yang baru.

\section{d. Cara membuat dendogram}

Sebuah dendogram adalah sebuah gambar yang menyajikan gerombolan konsep yang kognitif, didasarkan pada cara bicara (atau teks) yang Anda masukkan dan analisis. Biasanya tampak seperti contoh berikut:

- Pertama buka file exclude, untuk mengaktifkan file. File exclude tidak akan aktif kecuali jika Anda membukanya. Kemudian buka file teks yang ingin Anda analisis. Anda dapat menggunakan pilihan-pilihan setting yang disediakan dalam program komputer, termasuk ukuran layar, ukuran slide, jarak sisi kiri dan kanan, kelompok tehnik, dll. ${ }^{23}$

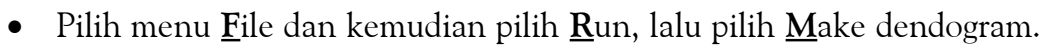
CatPac akan memberikan hasilnya dalam beberapa detik. Anda dapat mencetak dendogram secara langsung melalui pemilihan Print dalam menu File. Anda juga dapat menyimpan dendogram sebagai file *. den

${ }^{23}$ Penggunaan masing-masing pilihan dan cara memilih pilihan yang benar untuk teks dapat Anda dijumpai dalam Panduan bagi Para Pengguna CatPac. 
melalui pemilihan Save $\underline{\text { As }}$ di bawah menu File. (lihat contoh dendogram di bawah).

\section{CONTOH DENDOGRAM}

\begin{tabular}{|lrlc|}
\hline TOTAL KATA-KATA & 96 & AMBANG BATAS & 0.000 \\
TOTAL KATA KHUSUS & 25 & KEKUATAN PERBAIKAN & 0.100 \\
TOTAL EPISODE & 101 & SIKLUS & 1 \\
TOTAL BARIS & 27 & FUNGSI & Hiperbolik \\
& & APITAN & Ya \\
\hline
\end{tabular}

\section{DAFTAR BERDASARKAN FREKUENSI}

\begin{tabular}{|l|r|r|r|r|}
\hline & & & CASE & CASE \\
KATA & FREK & PCNT & FREK & PCNT \\
\hline FORÊT (forest) & 25 & 26.0 & 94 & 93.1 \\
SAUVAGES (wild) & 8 & 8.3 & 48 & 47.5 \\
DONNE (give) & 5 & 5.2 & 34 & 33.7 \\
MANGUES (mango) & 4 & 4.2 & 27 & 26.7 \\
MIEL (honey) & 4 & 4.2 & 31 & 30.7 \\
NKONO & 4 & 4.2 & 28 & 27.7 \\
NOYAUX (pits) & 4 & 4.2 & 28 & 27.7 \\
TROUVE (find) & 4 & 4.2 & 36 & 35.6 \\
ANIMAUX (animals) & 3 & 3.1 & 21 & 20.8 \\
IGNAMES (yams) & 3 & 3.1 & 28 & 27.7 \\
MANGER (to eat) & 3 & 3.1 & 21 & 20.8 \\
MOABI [a tree] & 3 & 3.1 & 28 & 27.7 \\
MOI (me) & 3 & 3.1 & 21 & 20.8 \\
PARTIE (part) & 3 & 3.1 & 9 & 8.9 \\
CHOSE (thing) & 2 & 2.1 & 10 & 9.9 \\
MANGUIERS & 2 & 2.1 & 10 & 9.9 \\
NÉS (born) & 2 & 2.1 & 13 & 12.9 \\
PRODUITS (products) & 2 & 2.1 & 14 & 13.9 \\
SE [reflexive, self] & 2 & 2.1 & 14 & 13.9 \\
VIANDE (meat) & 2 & 2.1 & 14 & 13.9 \\
VIE (life) & 2 & 2.1 & 14 & 13.9 \\
VIS (lives) & 2 & 2.1 & 14 & 13.9 \\
VIVRE (to live) & 2 & 2.1 & 14 & 13.9 \\
ANCÊTRES (ancestors) & 1 & 1.0 & 7 & 6.9 \\
AUCUN (none) & 1 & 1.0 & 7 & 6.9 \\
\hline
\end{tabular}

DAFTAR MENURUT ABJAD YANG DIURUTKAN

\begin{tabular}{|l|r|r|r|r|}
\hline & & & CASE & CASE \\
KATA & FREK & PCNT & FREK & PCNT \\
\hline ANCÊTRES & 1 & 1.0 & 7 & 6.9 \\
ANIMAUX & 3 & 3.1 & 21 & 20.8 \\
AUCUN & 1 & 1.0 & 7 & 6.9 \\
CHOSE & 2 & 2.1 & 10 & 9.9 \\
DONNE & 5 & 5.2 & 34 & 33.7 \\
FORÊT & 25 & 26.0 & 94 & 93.1 \\
IGNAMES & 3 & 3.1 & 28 & 27.7 \\
MANGER & 3 & 3.1 & 21 & 20.8 \\
MANGUES & 4 & 4.2 & 27 & 26.7 \\
MANGUIERS & 2 & 2.1 & 10 & 9.9 \\
MIEL & 4 & 4.2 & 31 & 30.7 \\
MOABI & 3 & 3.1 & 28 & 27.7 \\
MOI & 3 & 3.1 & 21 & 20.8 \\
NKONO & 4 & 4.2 & 28 & 27.7 \\
NOYAUX & 4 & 4.2 & 28 & 27.7 \\
NÉS & 2 & 2.1 & 13 & 12.9 \\
PARTIE & 3 & 3.1 & 9 & 8.9 \\
PRODUITS & 2 & 2.1 & 14 & 13.9 \\
SAUVAGES & 8 & 8.3 & 48 & 47.5 \\
SE & 2 & 2.1 & 14 & 13.9 \\
TROUVE & 4 & 4.2 & 36 & 35.6 \\
VIANDE & 2 & 2.1 & 14 & 13.9 \\
VIE & 2 & 2.1 & 14 & 13.9 \\
VIS & 2 & 2.1 & 14 & 13.9 \\
VIVRE & & & & \\
\hline & & & \\
& 2.1 & 14 & 13.9 \\
& 2 & & \\
\hline
\end{tabular}




\section{METODE WARDS}

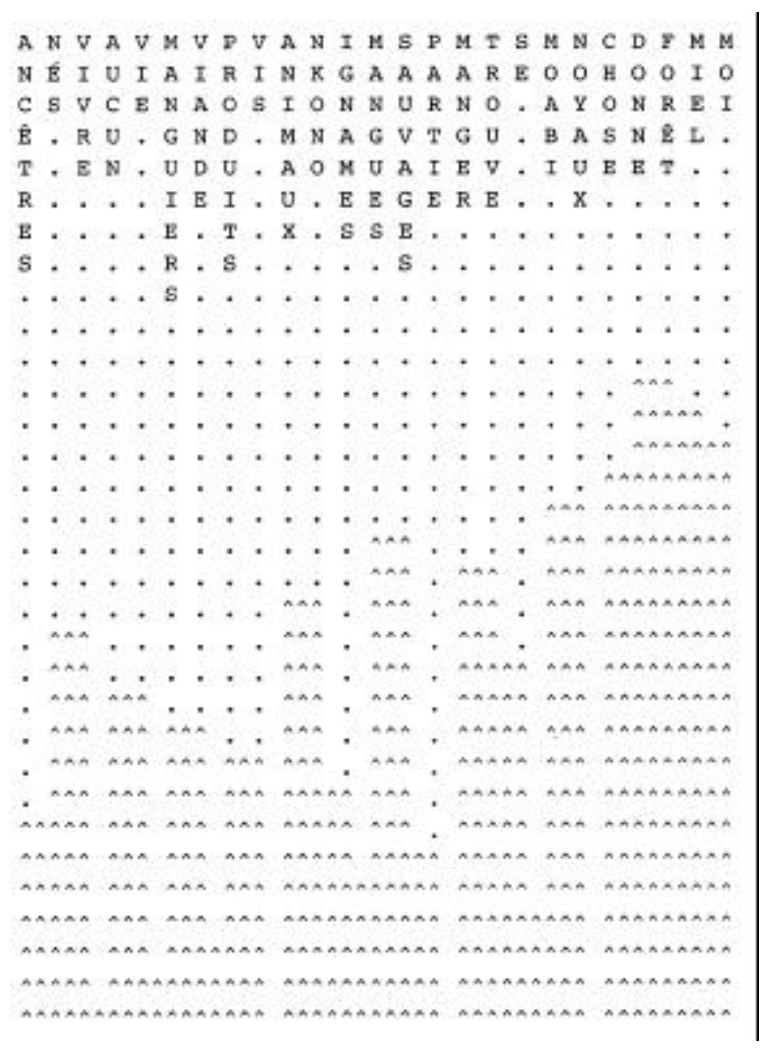




\section{Interpretasi:}

Data ini memperlihatkan kepada Anda suatu penggerombolan kata-kata yang dicatat dalam teks secara visual. Kepentingan gerombol ini berasal dari pendapat bahwa kata-kata yang diucapkan oleh seseorang sampai tingkat tertentu menggambarkan apa yang mereka pikirkan. Jika demikian, misalnya, kata 'hutan' dan 'baik' kerap muncul bersamaan (membentuk suatu gerombol), kita bisa menyimpulkan bahwa penduduk menganggap hutan itu baik, yang mungkin akan ditafsirkan sebagai dukungan terhadap kelestarian. Dalam beberapa contoh di atas, kata-kata dalam bahasa Perancis untuk benda (chose), memberi (donne), hutan (forêt), madu (miel), dan saya (moi) mewakili gerombol yang paling penting. Contoh ini menunjukkan pentingnya madu dalam mengelola hutan lokal. Biji-bijian (noyaux) dan moabi (sejenis pohon di Kamerun) merupakan gerombol lain yang penting, yang erat kaitannya dengan yang sebelumnya, menunjukkan bahwa barangbarang ini merupakan hasil hutan yang penting yang dimanfaatkan oleh penduduk. Penggerombolan kata-kata dalam pembicaraan penduduk tentang suatu topik seperti hutan (atau isu lain yang dapat diteliti) memberikan petunjuk yang penting tentang hubungan antara hutan dan elemen-elemen lain dalam lingkungan lokal, manusia dan lainnya.

\section{e. Cara membuat peta kognitif ${ }^{24}$ menggunakan CatPac}

- CatPac juga memiliki kemampuan untuk membuat peta kognitif. Anda dapat memperoleh peta kognitif ini dengan cara menyimpan file

24 Peta kognitif dapat digunakan untuk membantu interpretasi gerombol. Peta kognitif sering memberikan konfigurasi yang sama dengan dendogram, tetapi kadang dapat memberikan pengertian baru. Jika dua metode yang digunakan memberikan hasil yang berbeda, direkomendasikan untuk menggunakan hasil yang diberikan oleh dendogram karena lebih akurat. 
dendogram sebagai sebuah file koordinat (*.crd). Anda akan dituntun ke kotak dialog, klik OK dan ketik nama file koordinat Anda.

- Anda dapat membuka piranti lunak Terra vision ${ }^{25}$, kemudian buka file koordinat. Anda dapat melakukan beberapa proses pada gambar (misalnya, memutar gambar, mengurangi, menambahkan, mengubah kubus, warna penuh atau pudar, dll).

- Setelah Anda puas dengan tampilan gambar, Anda dapat mengkopi dan menampilkannya pada piranti lunak lainnya melalui pilihan $\underline{\text { Copy }}$ (Ctrl+Ins) di bawah menu Edit. Anda dapat melihat peta kognitif sederhana di bawah ini.

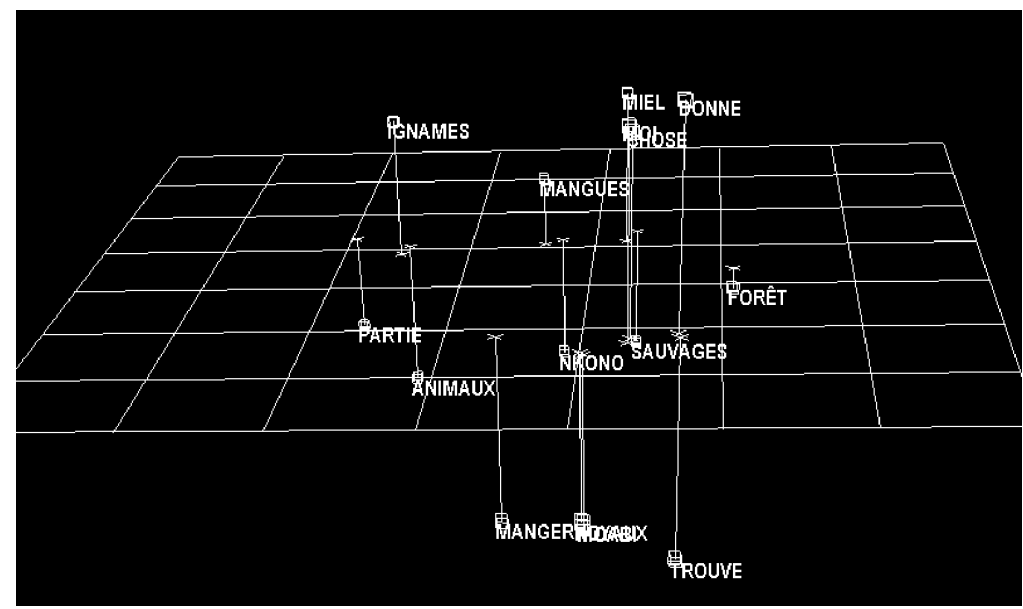

GAMBAR 2. Peta kognitif untuk wanita Baka (Kawasan Lindung Dja, Kamerun).

25 Terra vision adalah sebuah program pelengkap bagi CatPac. Program ini akan diinstal secara otomatis saat Anda menginstal CatPac. 
Peta kognitif ini kadang bermanfaat untuk memperoleh visualisasi kasar yang mewakili pikiran responden. Anda juga dapat melihat hubungan yang dekat antara madu (miel), saya (moi), benda (chose), dan memberi (donne). Hutan (forêt) tampil lebih dulu dibandingkan satu perkiraan dari analisis gerombol. Ke arah bawah ada dua istilah yang tidak dapat dibaca, yaitu biji-biji (noyaux) dan moabi (sejenis pohon yang berharga di Kamerun).

\section{B. ANALISIS METODE-METODE UNTUK KEAMANAN AKSES ANTARGENERASI TERHADAP SUMBER DAYA}

Bagian ini mencakup panduan analisis untuk tiga metode penilaian dalam ilmu sosial: Matriks Sejarah-Ekologi, Akses suatu Generasi terhadap Sumber Daya, dan Pembagian Manfaat di antara Para Stakeholder. Bagian ini sangat berguna dalam menilai keamanan akses antargenerasi terhadap sumber daya dalam hutan-hutan tertentu di antara kelompok-kelompok masyarakat tertentu.

\section{PANDUAN MATRIKS SEJARAH-EKOLOGI}

\section{a. Memasukkan data}

Anda dapat mengikuti format seperti yang ditunjukkan dalam Gambar 3. Sumber daya yang diidentifikasi di lapangan dicatat di bagian atas (palem, daging sapi, egusi), sementara tahun dicatat secara vertikal. Anda tidak harus memasukkan data dalam urutan tahun, tetapi kami menyarankan agar Anda melakukannya sehingga mudah dibaca. 


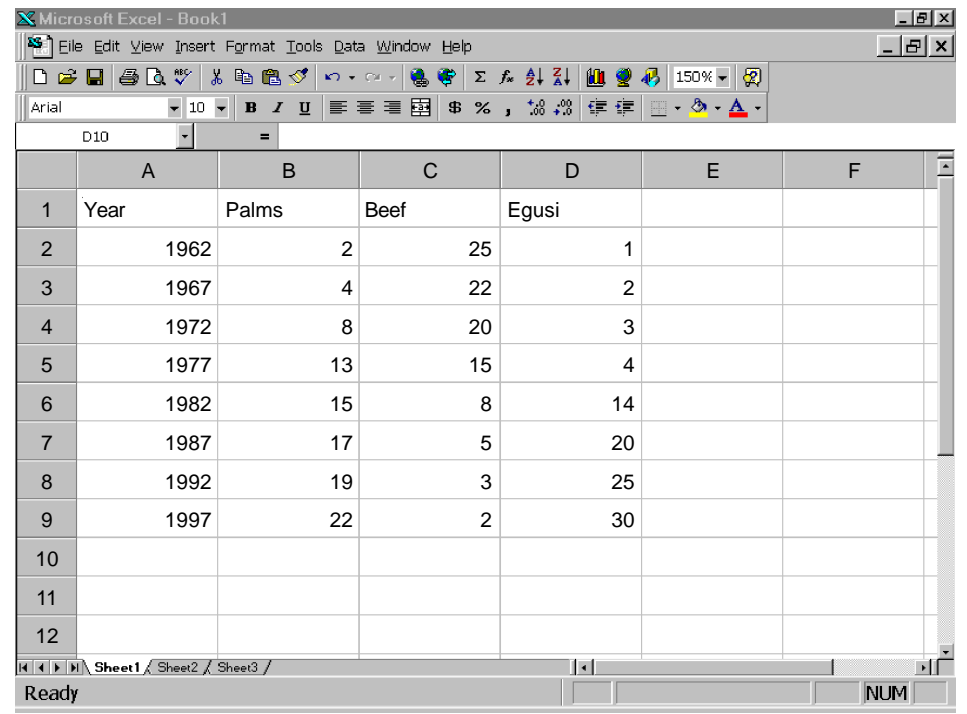

GAMBAR 3. Format lembar isian data sejarah-ekologi.

\section{b. Memeriksa kecenderungan linear dalam suatu kurun waktu}

Anda dapat memeriksa apakah data menunjukkan suatu kecenderungan dalam suatu kurun waktu, melalui penggunaan fasilitas regresi dalam program Excel. Tambahkan perintah regresi ke dalam Excel dengan menginstal program Add-ins. 
Ikuti program instal berikut ini:

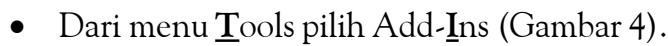

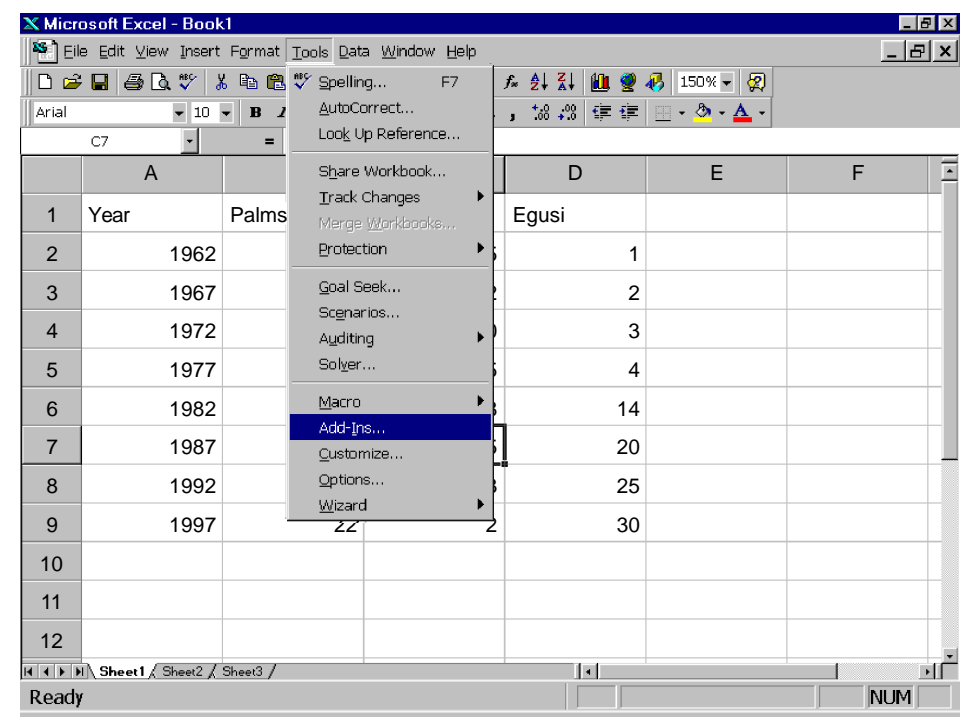

GAMBAR 4. Memilih submenu Add-Ins (data sejarah-ekologi).

Klik Analisis ToolPak dan Analisis ToolPak-VBA (Gambar 5). Jangan klik option jika telah ditandai, yang berarti program Add-ins telah diinstal di komputer Anda. 


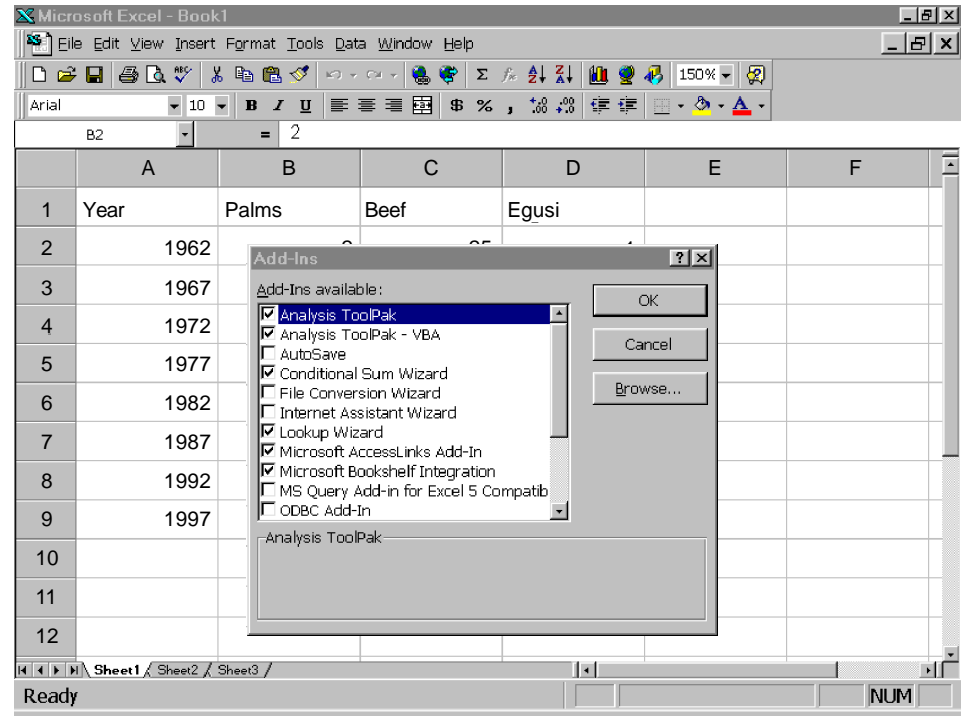

GAMBAR 5. Memilih program khusus Add-I $n s$ (data sejarah-ekologi).

- Setelah Anda menginstal program ini, Anda akan melihat ada submenu

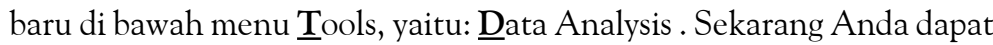
membuat analisis regresi melalui pemilihan submenu ㅁata Analysis.

- Anda akan dituntun oleh menu dialog yang ditunjukkan dalam Gambar 6. Pilih regression dari daftar analysis tools yang ada dan kemudian klik OK (Gambar 6). 


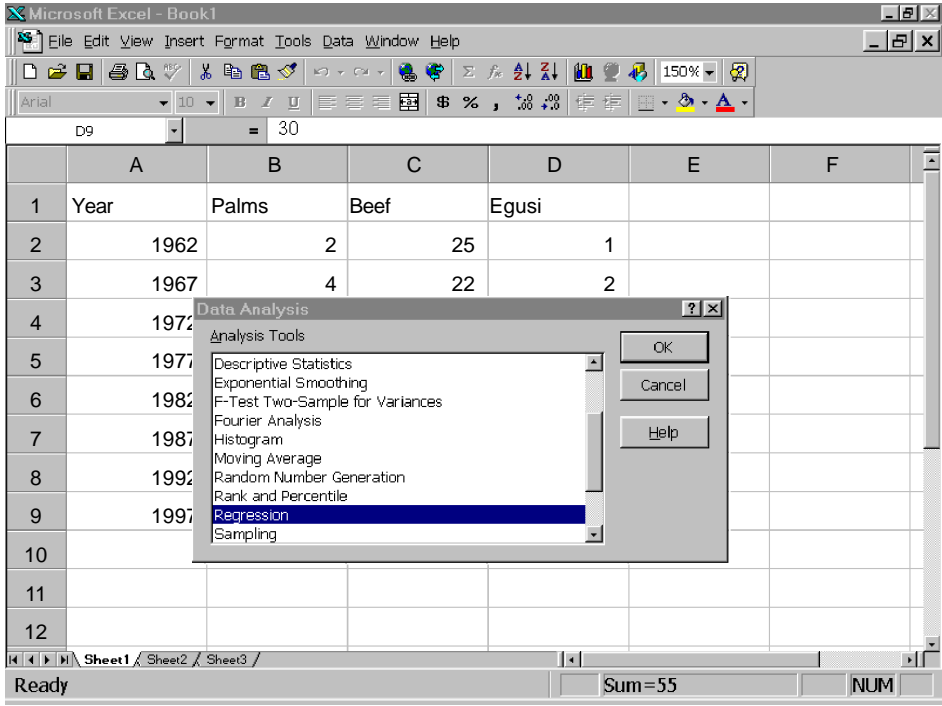

GAMBAR 6. Memulai analisis regresi untuk data sejarah-ekologi.

- Tahap selanjutnya adalah menentukan kisaran ( 'cells' dalam lembar isian berisi data) untuk variabel terikat (Y) dan variabel bebas (X). Masukkan cells dalam sebuah menu dialog seperti yang ditunjukkan dalam Gambar 7. Misalnya, jika Anda ingin memeriksa kecenderungan Palem dalam contoh di atas, Anda dapat menjadikan Palem sebagai variabel terikat dan Tahun (waktu) sebagai variabel bebas. Jangan lupa klik Residual Plot, Line Fit Plot dan Normal Probability Plot, karena selanjutnya Anda akan membutuhkannya untuk memeriksa kelayakan model. Kemudian klik OK. 


\begin{tabular}{|c|c|c|c|c|c|}
\hline \multicolumn{5}{|c|}{$\mathbb{Z}$ Micros oft Excel-Book1 } & $-\mid \nabla x$ \\
\hline \multicolumn{5}{|c|}{ 崹 Elle Edit Vlew Insert Format Iools Data window Help } & $-\nabla x$ \\
\hline \multicolumn{6}{|c|}{ 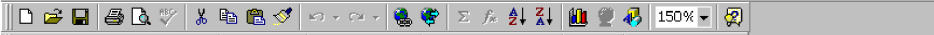 } \\
\hline \multirow[t]{3}{*}{ Arial } & -10 & 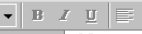 & 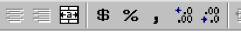 & $E=1=-2 . \underline{A}$. & \\
\hline & 09 & $=30$ & & & \\
\hline & A & B & Regression & & $?[x$ \\
\hline 1 & Year & Palms & $B \epsilon{ }^{-I n p u t-}$ & 87.89 & ok \\
\hline 2 & 1962 & 2 & 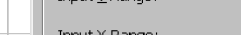 & & Cancel \\
\hline \multirow{2}{*}{3} & 1967 & 4 & Input Range: & A2:A9 & \\
\hline & & & $\Gamma$ Labels & $\Gamma$ Constant is Zero & Help \\
\hline 4 & 1972 & 8 & $\Gamma$ Confidence Level & 95 \% & \\
\hline 5 & 1977 & 13 & & & \\
\hline 6 & 1982 & 15 & Ouput options & & \\
\hline 7 & 1987 & 17 & C New Worksheet Ply: & & \\
\hline 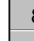 & 1992 & 19 & C New workbook & & \\
\hline 9 & 1997 & 22 & Residuals & $\sqrt{\square}$ Residual Plots & \\
\hline 10 & & & $\Gamma$ Standardized Residuals & V Line Fit Plots & \\
\hline 1 & & & Normal Probability & & \\
\hline 12 & & & IV Nor mal Probability Plots & & \\
\hline \multicolumn{6}{|c|}{ 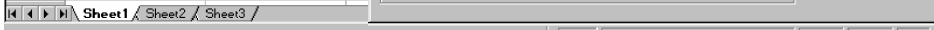 } \\
\hline \multicolumn{3}{|c|}{ Ready } & & Sum $=55$ & NUM \\
\hline
\end{tabular}

GAMBAR 7. Penentuan kisaran variabel dalam cells (data sejarah-ekologi).

- Hasil analisis yang akan Anda peroleh ditunjukkan dalam Gambar 8. Anda dapat memeriksa tingkat signifikansi model ini dengan melihat nilai-p (ditunjukkan oleh tanda panah). Jika nilai-p di bawah 5\% $(0,05)$, dapat disimpulkan bahwa data membentuk pola linier ${ }^{26}$ terhadap waktu.

${ }^{26}$ Jika Anda menemukan nilai-p tidak nyata, bukan berarti data tidak memiliki pola atau kecenderungan dalam suatu kurun waktu. Data ini mungkin memiliki kecenderungan nonlinear (misalnya, kuadrat, kubik, dll.). Excel tidak menyediakan perangkat analisis untuk kecenderungan yang nonlinear. Untuk kepentingan ini Anda dapat menggunakan piranti lunak statistik lainnya, seperti SPSS, SAS atau Minitab. 
Kemiringan garis menunjukkan kepada Anda informasi penting tentang perubahan persepsi penduduk terhadap sumber daya dalam suatu kurun waktu. Jika kemiringan bernilai negatif, berarti jumlah sumber daya yang ada dipandang berkurang. Jika kemiringan bernilai positif, maka yang terjadi adalah kebalikannya, yaitu sumber daya yang ada meningkat. Anda juga dapat memeriksa bagaimana baiknya persamaan itu sesuai dengan data, dengan melihat $\mathrm{R}$-kuadrat. Makin tinggi nilai $\mathrm{R}$-kuadrat maka makin sesuai model yang kita peroleh. ${ }^{27}$

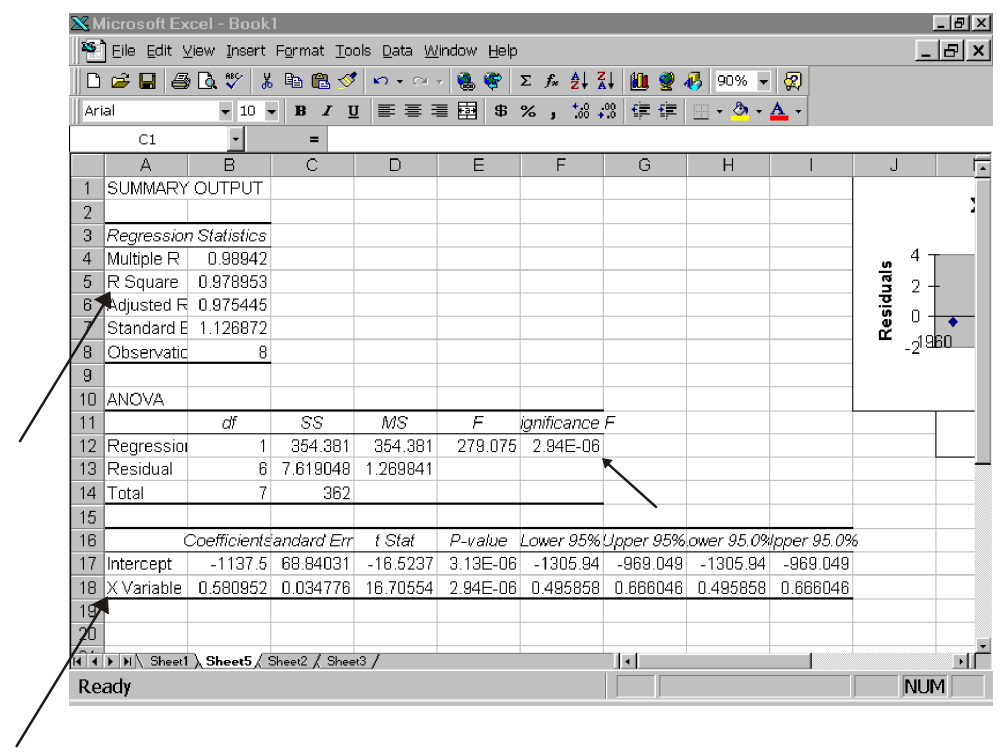

GAMBAR 8. Hasil analisis regresi untuk data sejarah-ekologi.

${ }^{27}$ R-kuadrat sangat sensitif terhadap pencilan dan observasi yang berpengaruh. Ada beberapa statistik pengganti R-kuadrat yang telah diintroduksi untuk menilai baiknya kesesuaian, termasuk statistik PRESS (Draper \& Smith 1982). Namun untuk model sederhana kami, cukup dengan R-kuadrat. 


\section{c. Memeriksa keabsahan model}

Analisis regresi, yang telah digunakan secara luas sebagai model untuk menunjukkan keterkaitan antara dua variabel, memiliki beberapa asumsi yang harus dipenuhi untuk menghasilan model yang absah (dapat diandalkan). Beberapa asumsi ini adalah kenormalan residual, homogenitas variansi residual, residual yang tidak berkorelasi, dll. Diskusi yang lebih rinci mengenai asumsi tersebut dapat ditemukan dalam (Draper \& Smith 1981), walaupun Lampiran A dalam panduan ini dapat memberikan pandangan bagaimana cara memeriksa asumsi-asumsi tersebut dengan menggunakan pendekatan penjelasan dan grafis. Namun kami sangat menyarankan Anda untuk menggunakan piranti lunak statistik, seperti Minitab, SAS dan SPSS untuk melakukan pemeriksaan yang lebih tepat. Karena data kami serupa dengan data time seri, lebih mungkin terdapat hubungan residual yang mengganggu asumsi-asumsi tersebut. Dalam kasus ini, regresi autoregresif (Makridakis dkk. 1983).

\section{PANDUAN AKSES SUATU GENERASITERHADAP SUMBERDAYA}

Bagian ini pertama menyediakan informasi tentang cara membuat lembar isian dan memasukkan data untuk metode distribusi kerikil dalam akses suatu generasi terhadap sumber daya (dalam PPD). Kemudian kami menjelaskan cara melakukan analisis statistik sederhana, terutama cara memeriksa distribusi data dan cara membuat tabel deskriptif sederhana. Bagi Anda yang puas dengan analisis sederhana, Anda dapat berhenti di bagian ini. Bagian terakhir adalah bagi Anda yang ingin melakukan analisis lanjutan, seperti menguji signifikan perbedaan persepsi di antara kelompok-kelompok yang berbeda (berdasarkan etnis, umur, jender, dll.). 


\section{a. Memasukkan data}

- Memasukkan data menggunakan program lembar kerja, seperti Excel atau Lotus.

- Memasukkan data demografi, misalnya kelompok pengguna, jender, umur, tingkat pendidikan, dll. dalam kolom-kolom sebelah kiri (Gambar 9, kolom-kolom A-D). Masukkan data demografi dengan kode nomor. Jika Anda memiliki data kategori, seperti jender, tingkat pendidikan, dll., Anda perlu mengubahnya menjadi kode nomor (misalnya, wanita $=0$, pria $=$ 1, dll.). Anda perlu mencatat arti dan menyimpan lembar kode ini, sehingga Anda selalu mengetahui arti dari masing-masing kode. Anda akan memerlukan lembar kode ini saat melakukan analisis. Kami sarankan Anda mencatat informasi pengkodean dalam lembar kerja.

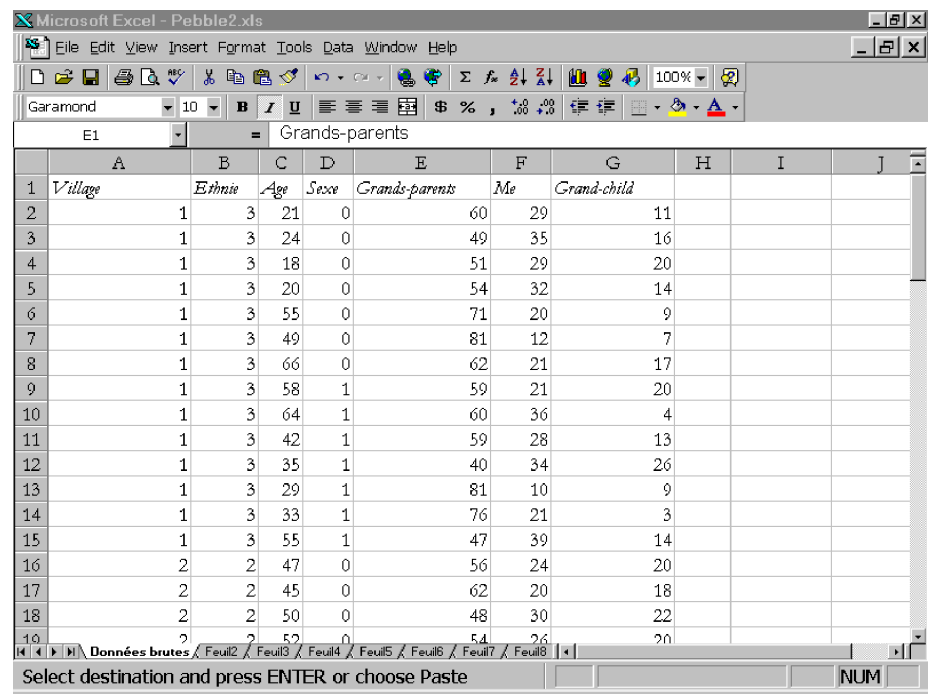

GAMBAR 9. Format lembar isian untuk data antargenerasi. 
- Anda dapat menggunakan kolom berikutnya untuk memasukkan jumlah kerikil untuk masing-masing generasi (misalnya, kakek-nenek, saya, $\mathrm{cucu}^{28}$ ) diletakkan setelah responden. Anda hanya membutuhkan satu baris untuk masing-masing responden.

- Setelah Anda selesai memasukkan semua data responden, jangan lupa menyimpan file ke dalam format Lotus 123 (*.wk1).

\section{b. Melakukan analisis data sederhana dengan metode SPSS ${ }^{29}$}

Kami menggunakan SPSS (Paket Statistik untuk Ilmu Sosial) untuk menganalisis data.

- Membuka data

Anda dapat membuka file Lotus 123 dalam lembar isian SPSS. Gunakan pilihan read variable name. ${ }^{30}$

- Membuat label data

Gunakan lembar kode yang telah Anda buat ketika membuat kode data demografi ke dalam sebuah kode nomor untuk pelabelan data. Untuk membuat label data, tempatkan kursor pada kolom di mana data demografi berada. Untuk tahap-tahap selanjutnya, kami berikan sebuah contoh label data jender.

${ }^{28}$ Biasanya kami menggunakan tiga kategori, kakek-nenek, saya dan cucu, tetapi Tim Kalimantan Timur (1997) menambahkan dua kategori: orang tua dan anak.

${ }^{29}$ Kami juga telah membuat panduan bagi Anda yang ingin melakukan analisis sederhana menggunakan Excel (lihat Bagian C).

${ }^{30}$ Dari pilihan menu SPSS, Anda dapat memilih File $\rightarrow$ Open, kemudian ubah tipe file ke Lotus (*wk1) dan pilihlah file yang ingin Anda buka. Processor SPSS secara otomatis akan menanyakan apakah Anda ingin membaca nama variabel atau tidak. Tentukan pilihan 'read the variable names'. 
Pilih dari menu

$\underline{\text { Data }}$

Define variable (Gambar 10)

Klik tombol Label (ditunjukkan oleh tanda panah). Anda akan diminta untuk memasukkan label (Gambar 11).

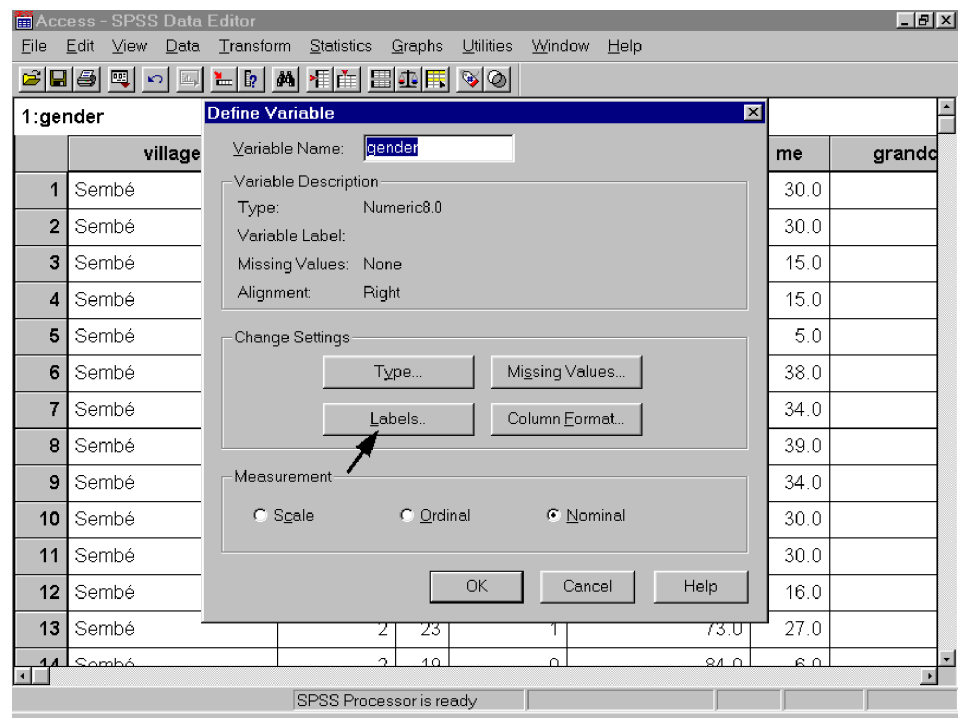

GAMBAR 10. Tombol label (data antargenerasi). 


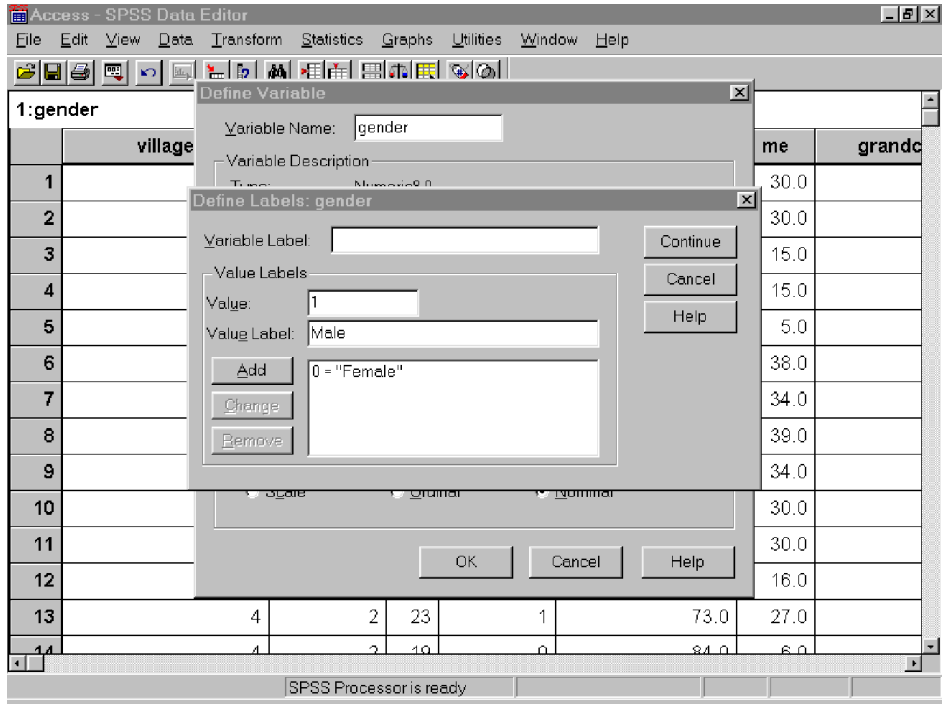

GAMBAR 11. Menentukan label untuk jender pada data antargenerasi.

> Masukkan label demografi (misalnya, Sekolah Menengah Pertama, dalam contoh di atas) dan ketika Anda selesai, klik Continue.

Ikuti prosedur yang sama untuk data demografi yang lain.

- Memeriksa distribusi data

Umumnya, kami menggunakan mean/rata-rata untuk mengukur distribusi kerikil menurut para responden. Namun, penggunaan rata-rata memiliki beberapa kelemahan ketika data tidak tersebar secara simetris atau ketika tidak ada satu atau lebih pencilan. Jika hal ini terjadi, kami dapat 
menggunakan median/nilai tengah. Untuk memeriksa apakah data tersebar secara simetris atau tidak kami menggunakan diagram kotak garis. Dengan metode ini kami memeriksa data untuk masing-masing generasi secara terpisah, karena generasi tersebut dipertimbangkan sebagai suatu variabel yang terpisah. Jika mayoritas generasi didistribusikan secara tidak simetris, kami akan menggunakan median. Lain halnya, jika mayoritas generasi didistribusikan secara simetris, kami harus menggunakan ratarata.

Anda dapat membuat sebuah diagram kotak garis melalui petunjuk berikut ini:

> Pilih dari menu

Graphs

Boxplot

Pilih simple dan summaries for separate variables (Gambar 12).

$>$ Klik tombol Define.

$>$ Masukkan semua generasi sebagai variabel (Gambar 13) dan kemudian klik OK.

$>$ Anda akan memperoleh diagram kotak garis seperti yang ditunjukkan dalam Gambar 14. Garis hitam di dalam kotak menunjukkan letakmedian. Garis yang lebih tinggi dan lebih rendah dari masing-masing kotak berturut-turut menunjukkan letak kuartil ke-3 dan ke-1. Jika data didistribusikan secara simetris dan jika median hanya terletak di tengahtengah kotak, maka jarak dari kuartil ke-3 dan ke-1 kira-kira sama. 


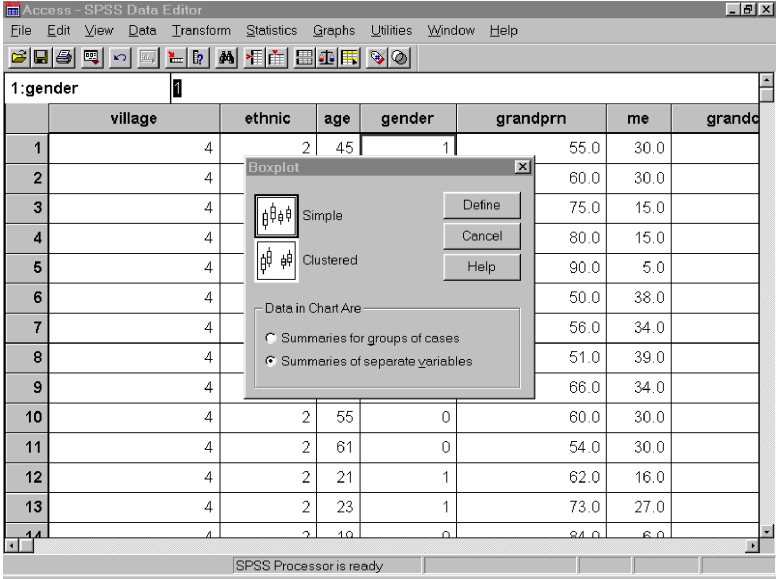

GAMBAR 12. Memilih tipe diagram kotak garis untuk data antargenerasi.

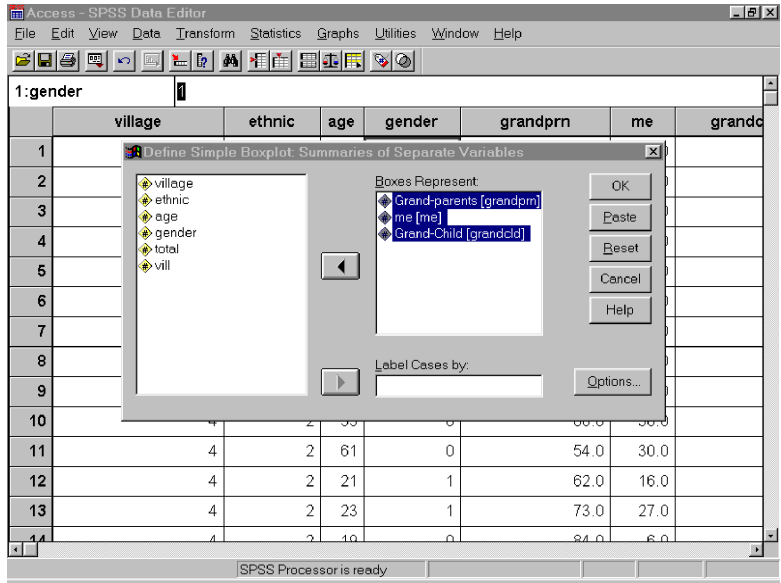

GAMBAR 13. Memilih variabel-variabel data antar-generasi (untuk memeriksa distribusi data). 


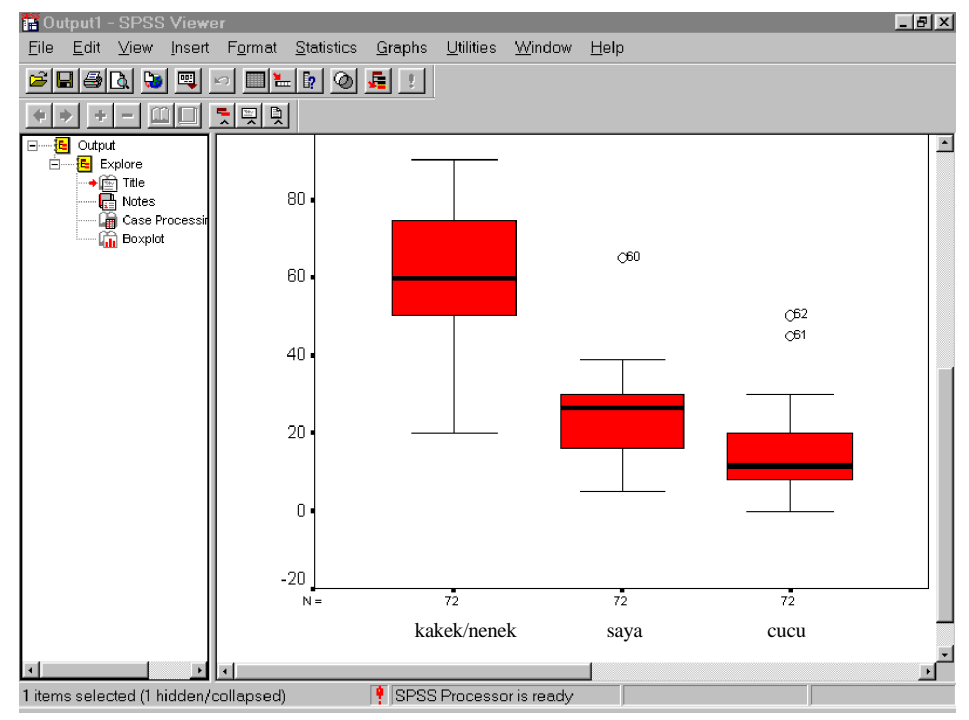

GAMBAR 14. Diagram kotak garis untuk data antargenerasi.

Jika distribusi data sangat tidak simetris atau ada beberapa pencilan (biasanya, ditunjukkan dengan tanda bintang atau lingkaran), kami sarankan Anda menggunakan median. Dalam diagram kotak garis di atas, kami pertimbangkan saya dan cucu memiliki distribusi yang tidak simetris karena letak median tidak simetris dan juga ada beberapa pencilan. Oleh sebab itu kami menggunakan median untuk menganalisis data antargenerasi.

- Menghasilkan tabel untuk menggambarkan distribusi akses antargenerasi terhadap sumber daya, menurut semua responden 
Pilih dari Menu

Statistics

Custom Tables

Basic Tables

Letakkan semua generasi dalam summaries. Anda dapat melakukan ini dengan memilih nama variabel dan kemudian mengklik tanda panah dalam kotak summaries (Gambar 15).

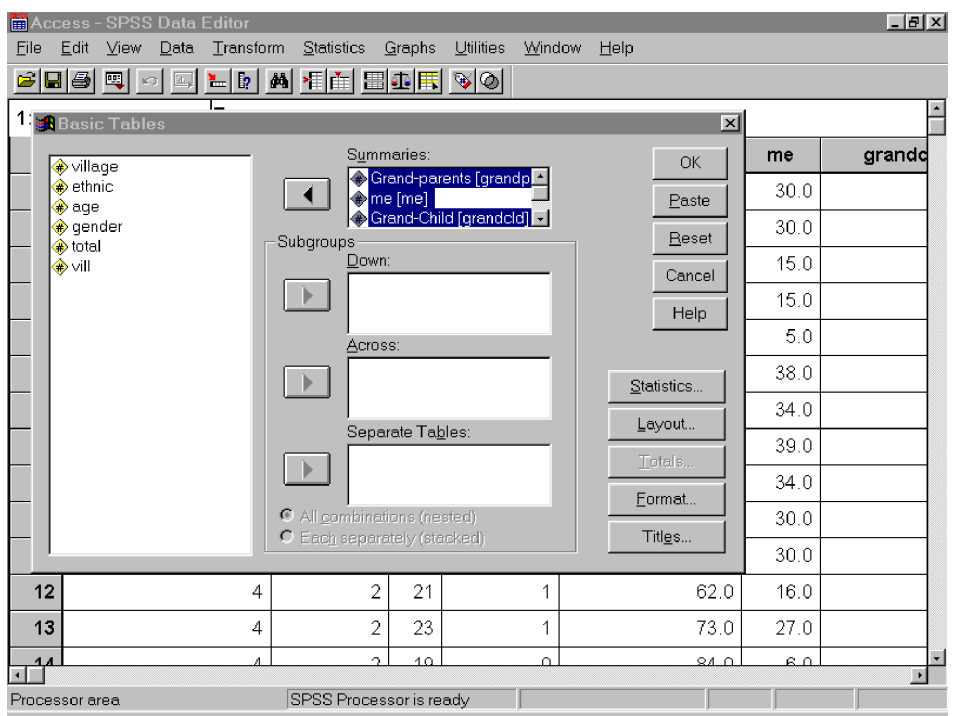

GAMBAR 15. Memilih variabel antargenerasi. 


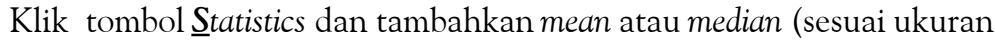
yang Anda ingin gunakan) sebagai cells statistik.

Klik tombol OK, maka Anda akan memperoleh hasil (Gambar 16).

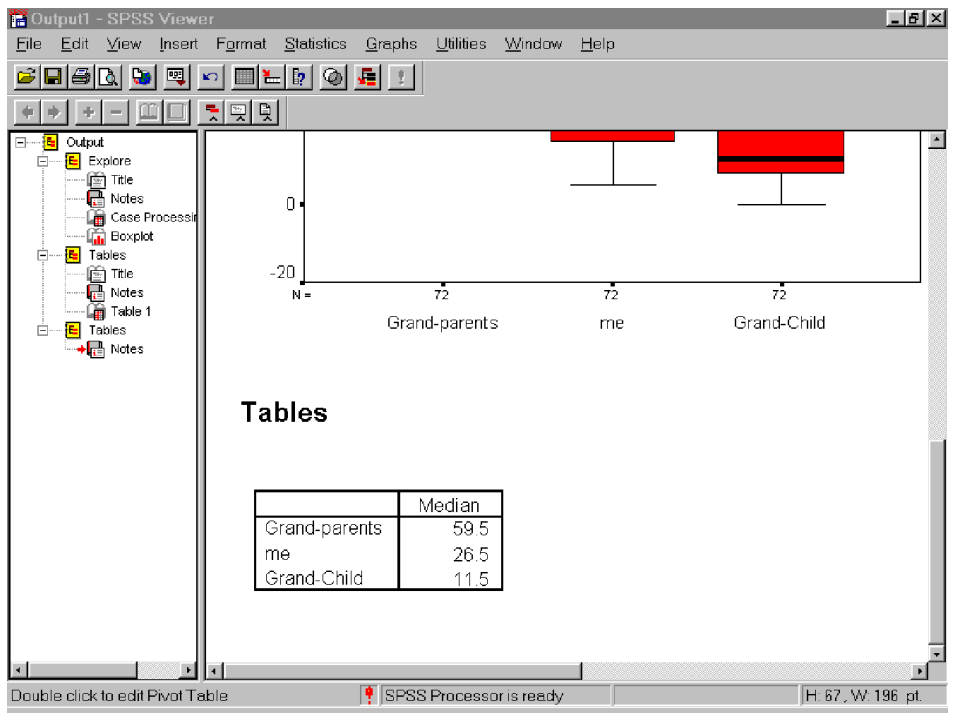

GAMBAR 16. Tabel SPSS menggambarkan akses antargenerasi terhadap sumber daya menurut semua responden. 


\section{c. Melakukan analisis sederhana dengan metode Excel}

- Menghasilkan tabel untuk menggambarkan distribusi kerikil, menurut semua responden

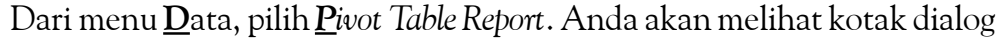
seperti yang ditunjukkan dalam Gambar 17.

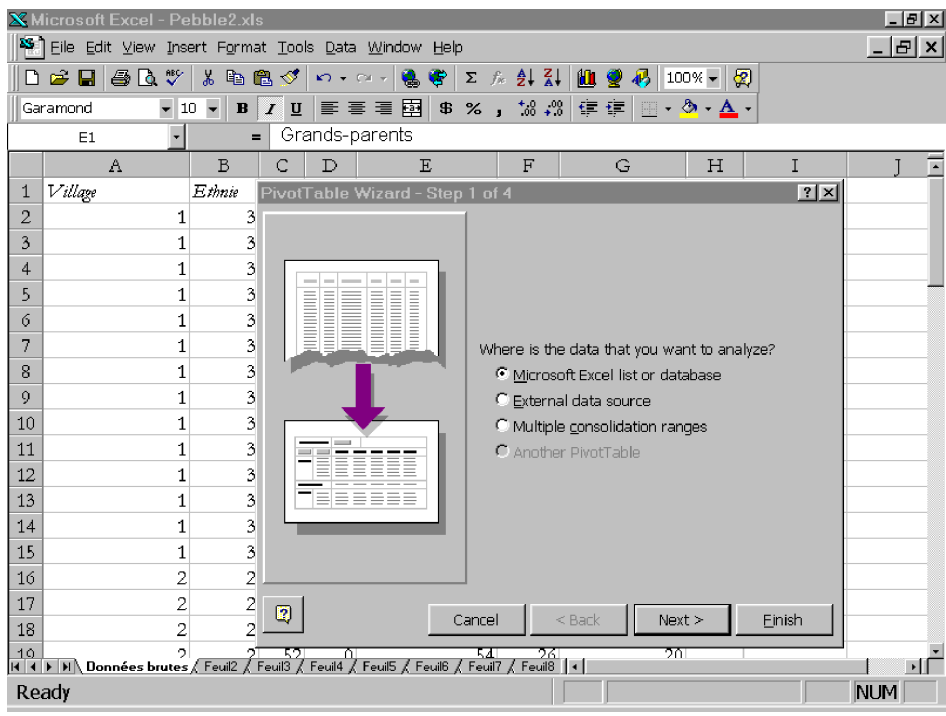

GAMBAR 17. Pola dasar tabel pivot (data antargenerasi).

Klik tombol Next $>$ dua kali, dan Anda akan melihat sebuah kotak dialog seperti yang ditunjukkan dalam Gambar 18 . 


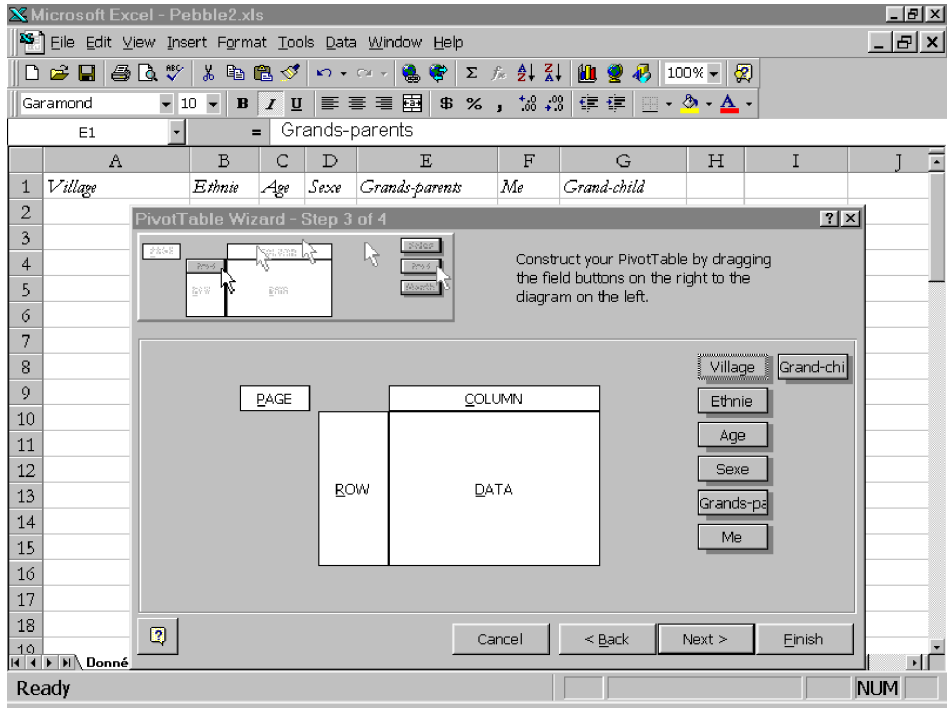

GAMBAR 18. Menyusun tabel pivot untuk analisis sederhana data antargenerasi (Tahap 1).

Tarik (drag) semua generasi ke dalam ruang data (Gambar 19).

Jumlah (sum) merupakan statistik yang sudah diset. Statistik ini dapat Anda ubah dengan menekan tombol dan memilih statistik yang ingin Anda hitung ${ }^{31}$ (Gambar 20).

31 Statistik yang disediakan dalam Excel tidak mencakup Median. Jika Anda ingin menggunakan Median, Anda perlu menggunakan perangkat lunak lainnya, seperti SPSS. 


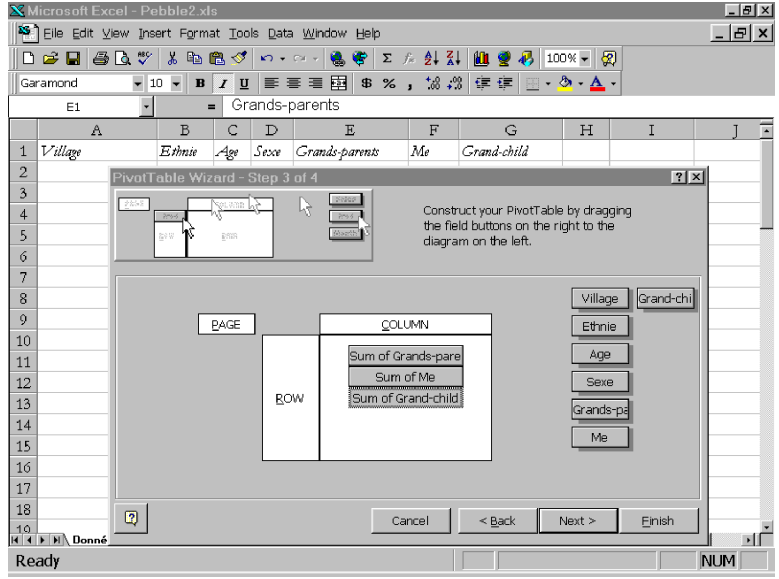

GAMBAR 19. Menyusun tabel pivot untuk analisis sederhana data antargenerasi (Tahap 2).

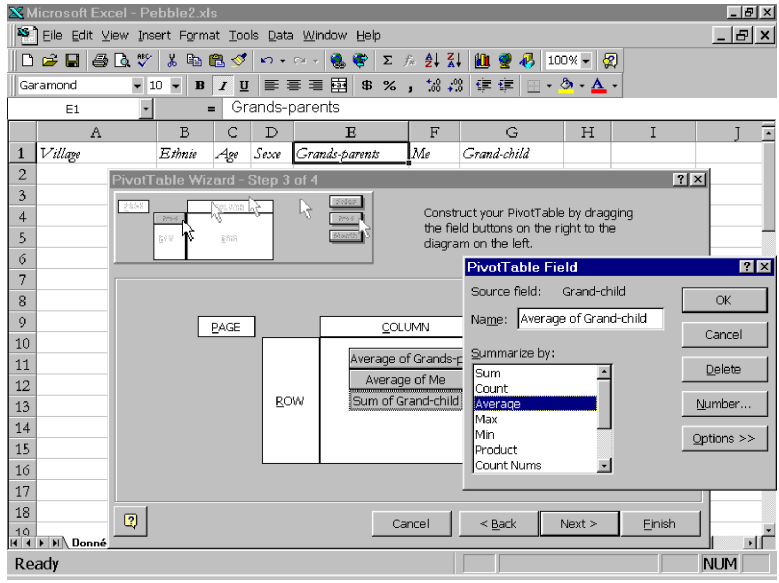

GAMBAR 20. Mengubah data statistik yang sudah diset pada data antargenerasi. 
Setelah Anda menetapkan statistik yang tepat, Anda dapat mengklik tombol Finish dan Anda akan memperoleh Tabel seperti yang ditunjukkan dalam Gambar 21. Jika Anda lebih menyukai jumlah digit yang lebih sedikit, Anda dapat menyesuaikan desimalnya. ${ }^{32}$

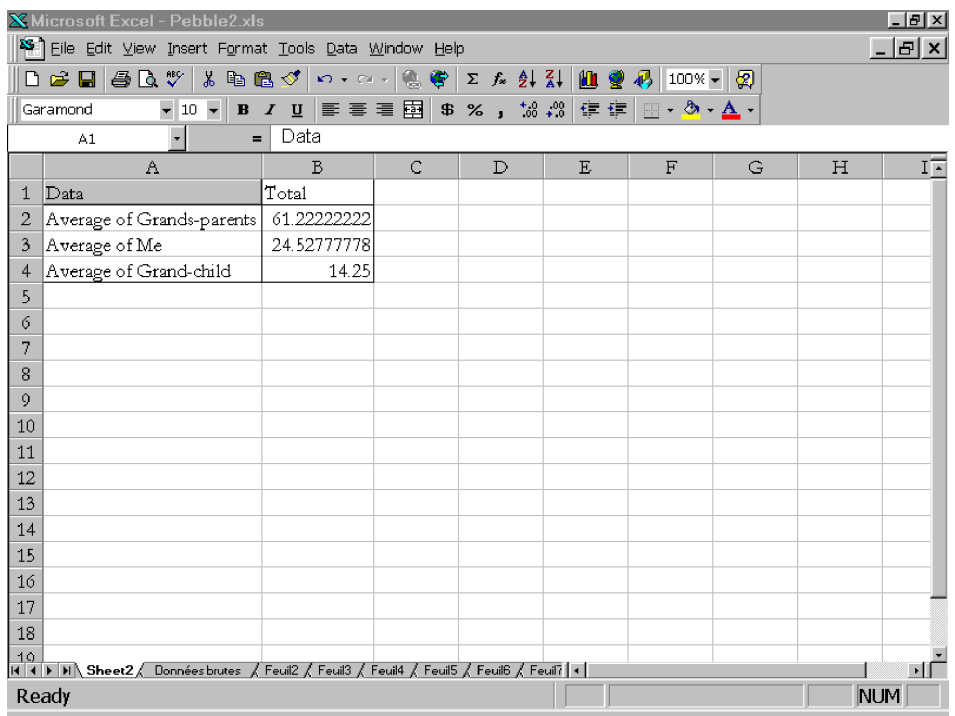

GAMBAR 21. Tabel MS Excel menggambarkan distribusi akses antargenerasi terhadap sumber daya menurut semua responden.

32 Untuk menyesuaikan desimal, gunakan menu Format, pilih cells dan di bawah kategori pilih Numbers. Kemudian Anda dapat menyesuaikan desimal yang Anda inginkan dengan meningkatkan atau menurunkan desimal yang sudah dicantumkan $($ default $=2)$. 


\section{d. Melakukan analisis data lanjutan dengan metode SPSS}

- Menghasilkan tabel yang menggambarkan distribusi antargenerasi terhadap sumber daya, menurut subkelompok tertentu

Terkadang menarik untuk membandingkan subkelompok yang berbeda dengan masing-masing elemen demografi (etnis, jender, tingkat pendidikan, dll.), berdasarkan persepsi mereka terhadap distribusi kerikil di antara para stakeholder. Untuk membandingkan persepsi subkelompok, kita perlu mengetahui gambaran distribusi kerikil di antara generasi-generasi menurut masing-masing subkelompok. Anda dapat mengikuti petunjuk-petunjuk di bawah untuk memperoleh gambaran ini. Kami memiliki responden yang berasal dari tiga kelompok etnis, Baka, Kako dan Nzime. ${ }^{33}$

\section{Pilih dari Menu}

Statistics

Custom Tables

$\underline{B}$ asic Tables

> Letakkan semua generasi dalam bagiansummaries. Anda dapat melakukan ini dengan memilih nama variabel dan kemudian meletakkan tanda panah di depan kotak summaries (Gambar 22).

33 Kelompok-kelompok etnis ini menetap di kawasan Cagar Alam Dja, Kamerun (Tchikangwa, 1998). 


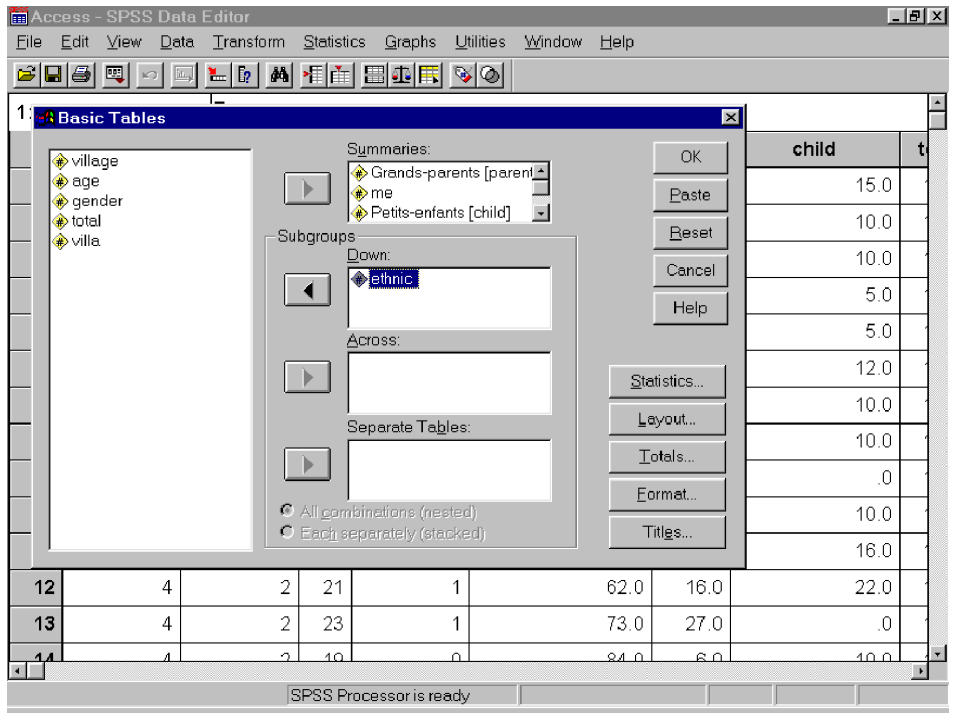

GAMBAR 22. Memilih variabel antargenerasi (telah diringkas).

Letakkan kolom yang berisi data subkelompok yang ingin kita bandingkan ke dalam subkelompok dalam urutan menurun (Gambar 23). Dalam kasus kami, informasi tentang etnis berada dalam kolom Ethnic. Klik OK. 


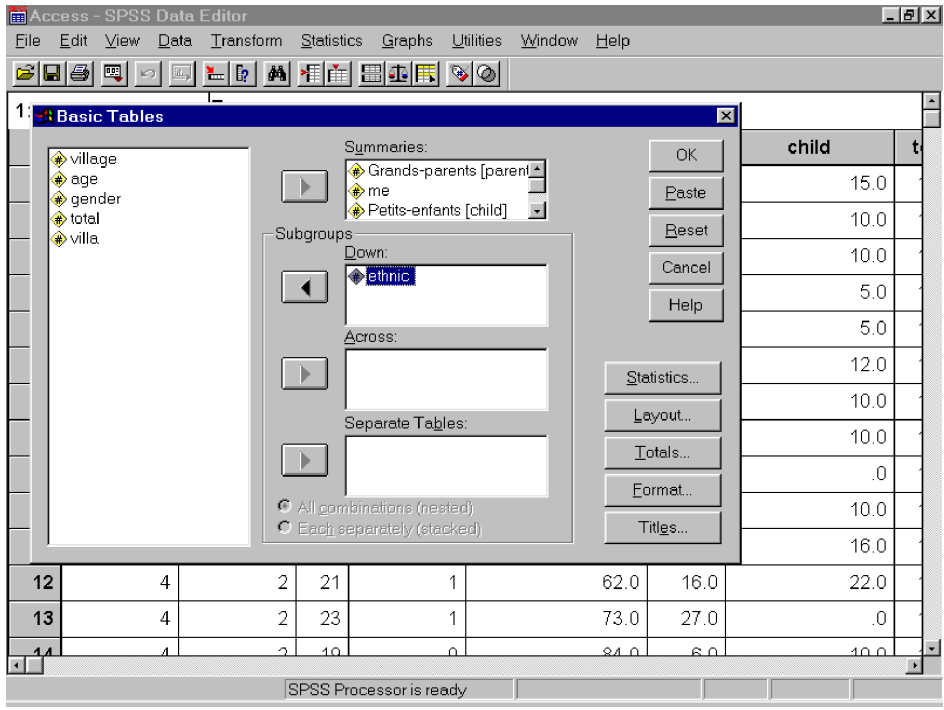

GAMBAR 23. Memilih variabel demografi data antargenerasi.

Sekarang kita dapat membandingkan perbedaan distribusi kerikil dari masing-masing generasi menurut tiga kelompok etnis (Gambar 24). 


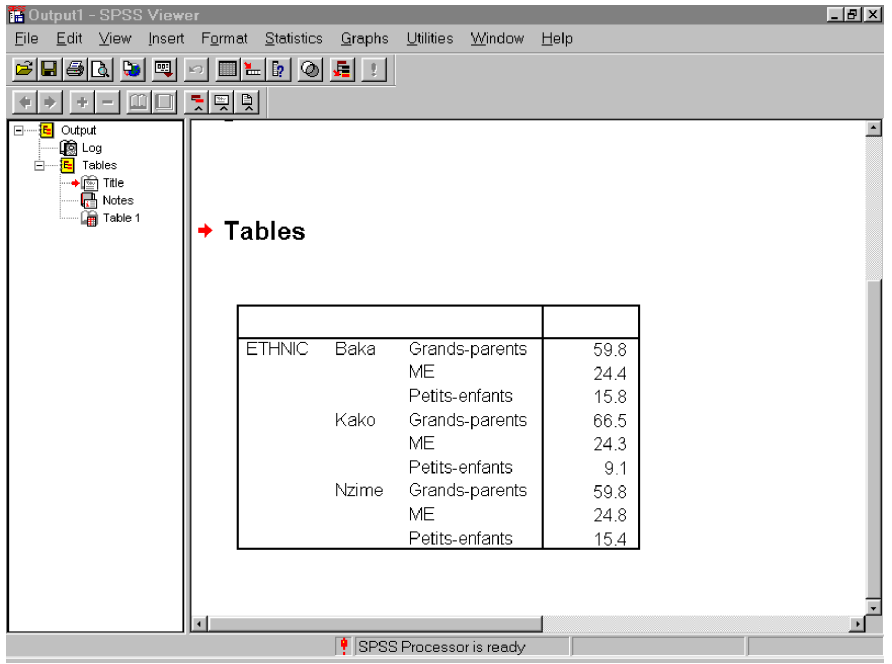

GAMBAR 24.Tabel SPSS menggambarkan perbandingan distribusi akses antargenerasi terhadap sumber daya berdasarkan etnis.

Jika Anda memiliki lebih dari tiga kategori data demografi (misalnya, empat atau lebih kelompok etnis), Anda dapat melanjutkan tahap yang sama ini untuk memperoleh nilaimean/median distribusi kerikil di antara para stakeholder untuk kategori yang lain.

- Menguji kesepakatan/ketidaksepakatan di antara kelompok-kelompok yang berbeda pada distribusi akses antargenerasi terhadap sumber daya -Anda dapat memeriksa ada tidaknya kesepakatan di antara kelompokkelompok ${ }^{34}$ yang berbeda mengenai jumlah kerikil yang diberikan untuk masing-masing generasi.

${ }^{34}$ Kelompok-kelompok ini dapat berupa jender, tingkat pendidikan, etnis, dll. 


\section{Pilih dari menu}

\section{Statistics}

Nonparametric test

$\underline{2}$ independent samples atau

$\underline{\text { Kindependent samples }}{ }^{35}$

\section{(Lihat Gambar 25)}

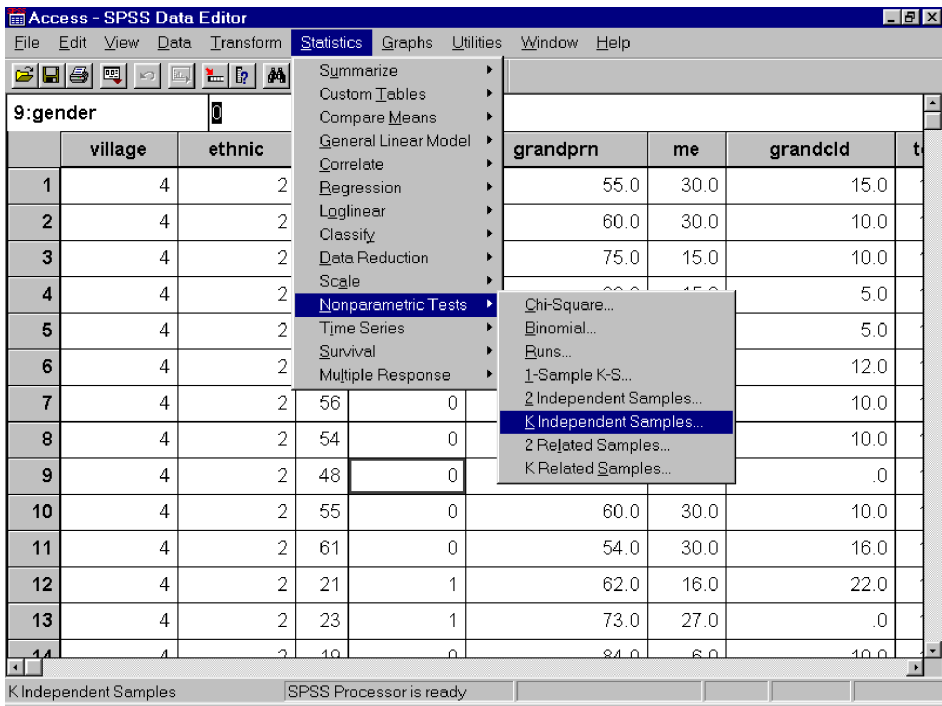

GAMBAR 25. Memilih tipe pengujian statistik untuk menguji kesepakatan data antargenerasi.

35 Jika Anda ingin menguji data hanya dengan dua kategori atau dua kelompok, Anda harus memilih 2 Independent Samples dan kemudian gunakan uji Mann-Whitney. Jika Anda menggunakan data lebih dari dua kategori, Anda harus memilih sampel K-independent, dan kemudian gunakan uji Kruskall-Wallis. 
Letakkan test variable ${ }^{36}$ ke dalam kotak test variable list dan kelompokkan variabel ke dalam kotak grouping variable (Gambar 26). Kemudian Anda harus menentukan nilai minimum dan maksimum dari grouping variable (Anda dapat melihat arti dari masing-masing kode pada lembar kode Anda). Rincian dapat dilihat pada Gambar 27.

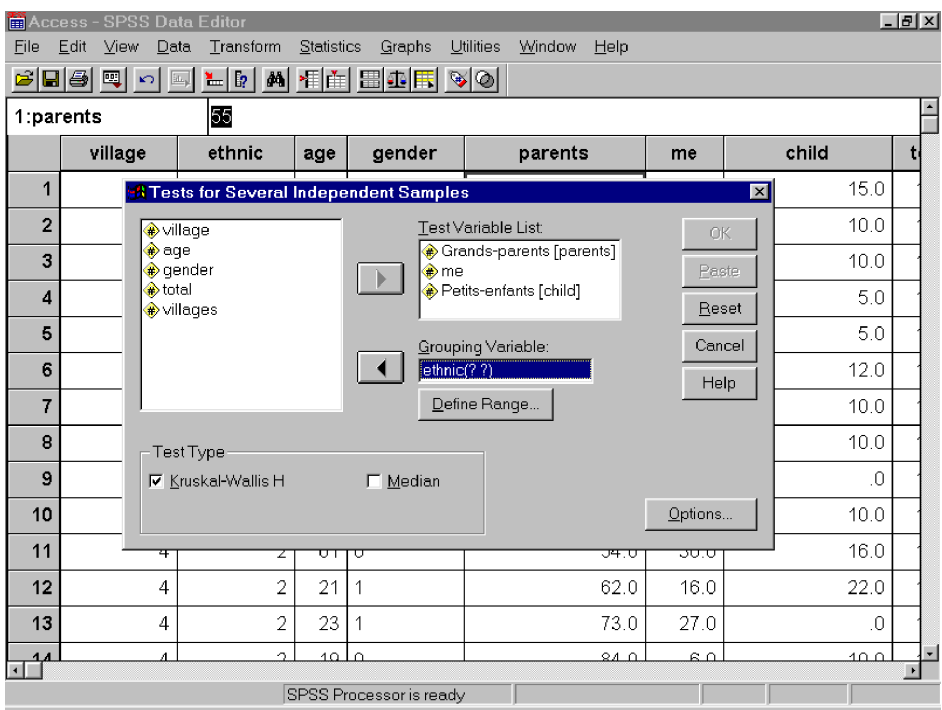

GAMBAR 26. Memilih test variable dan grouping variable (data antargenerasi).

36 Test variable harus mengandung kolom data kerikil untuk masing-masing generasi. Grouping variable merupakan kolom yang berisi informasi dari kelompok-kelompok yang berbeda yang ingin kami bandingkan. 


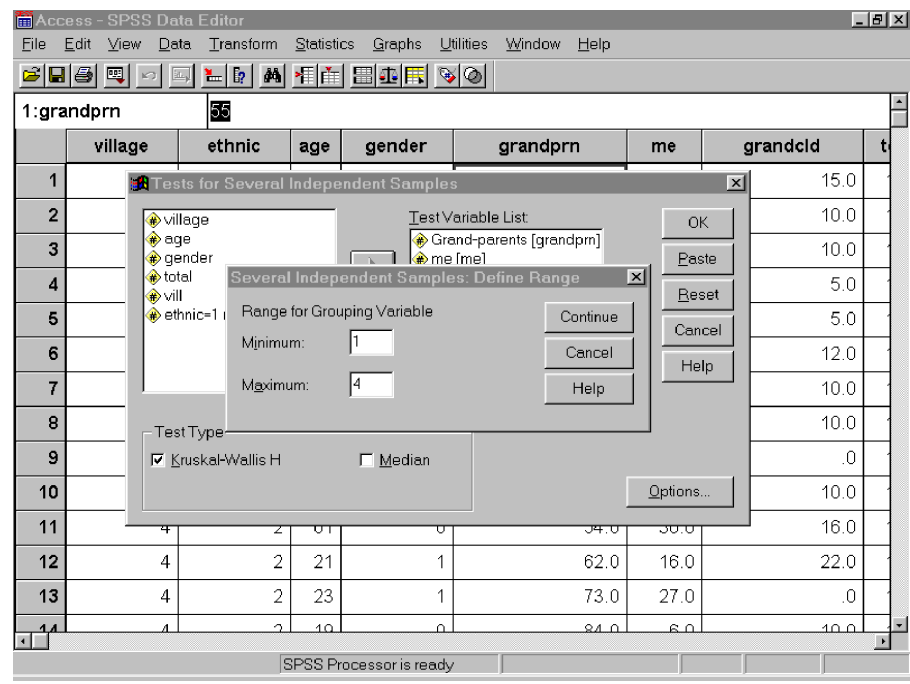

GAMBAR 27. Menentukan kisaran untuk grouping (demografi) variable (data antargenerasi).

Klik Continue dan kemudian OK.

Anda akan memperoleh hasil seperti yang ditunjukkan dalam Gambar 28. Pengujian dilakukan untuk masing-masing generasi. Pastikan untuk memeriksa signifikansi dari masing-masing pengujian.

Lihat nilai-p (ditunjukkan oleh tanda panah). Jika nilai-p berada di bawah 0,05, kita menolak hipotesis ketiadaan ${ }^{37}$ dan berkesimpulan ada ketidaksepakatan di antara kelompok-kelompok tentang jumlah kerikil

${ }^{37}$ Hipotesis ketiadaan adalah: Bahwa semua subkelompok mendapatkan jumlah kerikil yang sama untuk masing-masing generasi. Dengan kata lain, mereka setuju dengan jumlah kerikil yang relevan, yang diberikan untuk masing-masing generasi. 
yang dimiliki masing-masing generasi. Jika nilai-p berada di atas 0,05 kami berkesimpulan ada kesepakatan di antara kelompok-kelompok yang berbeda. Pengujian dilakukan untuk masing-masing generasi, pastikan untuk memeriksa signifikansi dari masing-masing generasi.

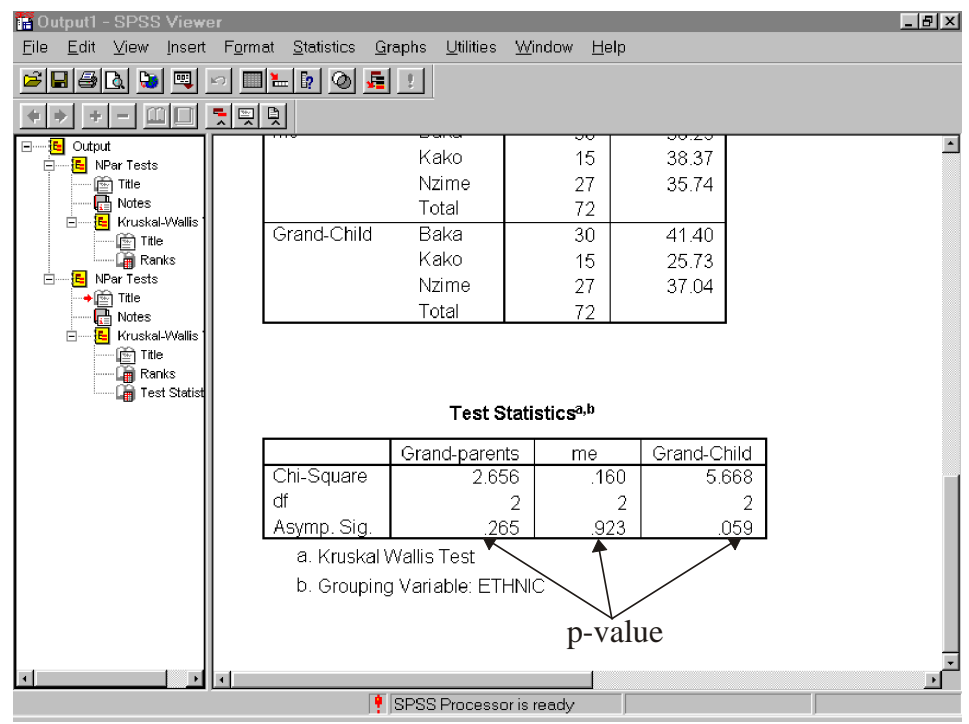

GAMBAR 28. Hasil pengujian statistik untuk masing- masing generasi (data antargenerasi).

\section{e. Melakukan analisis data lanjutan dengan metode Excel}

- Menghasilkan tabel yang menggambarkan distribusi kerikil, menurut subkelompok tertentu 
Anda dapat menggunakan prosedur yang sama seperti yang Anda lakukan untuk memperoleh sebuah tabel distribusi kerikil menurut semua responden (Bagian c dalam bab ini). Perbedaan-perbedaan akan ada ketika Anda membuat tabel pivot. Selain menarik semua generasi ke ruang data, Anda juga harus menarik kolom di mana subkelompok ${ }^{38}$ tertentu berada, ke dalam ruang kolom (Gambar 29). Di sini kami menggunakan kelompok-kelompok etnis sebagai suatu contoh.

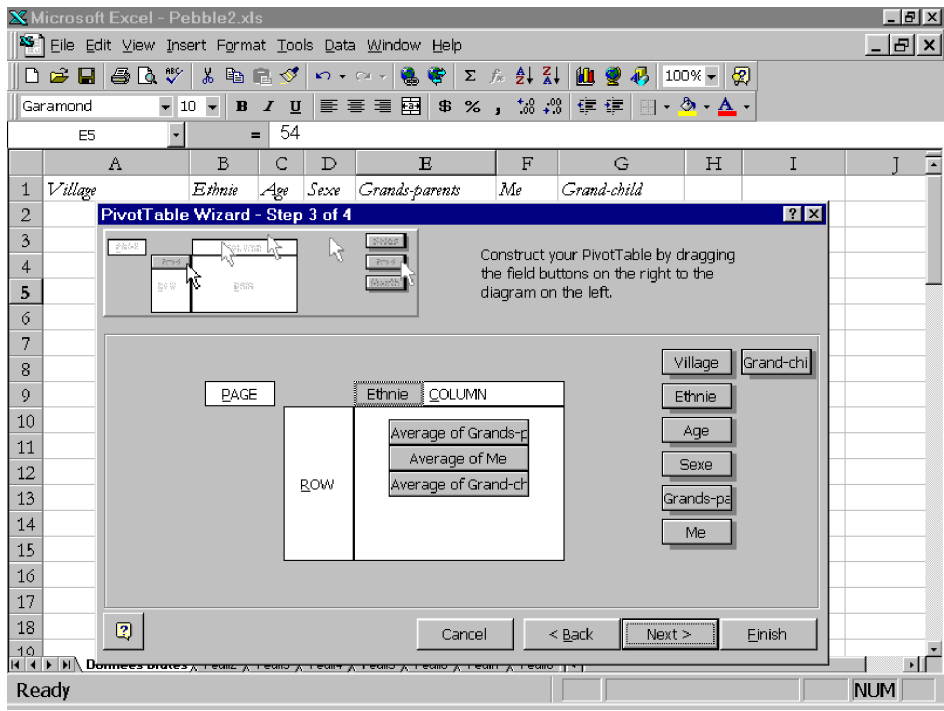

GAMBAR 29. Menyusun tabel pivot untuk analisis lanjutan data antargenerasi.

38 Subkelompok di sini dapat berupa jender, tingkat pendidikan, umur, etnis, dll. 
Dengan menekan tombol finish Anda akan memperoleh hasil (Gambar 30). Perhatikan dua subtabel untuk masing-masing kelompok etnis (dalam contoh ini, seperti dalam bagian sebelumnya, etnis 1 berarti Baka, etnis 2 berarti Kako, sementara etnis 3 berarti Nzime).

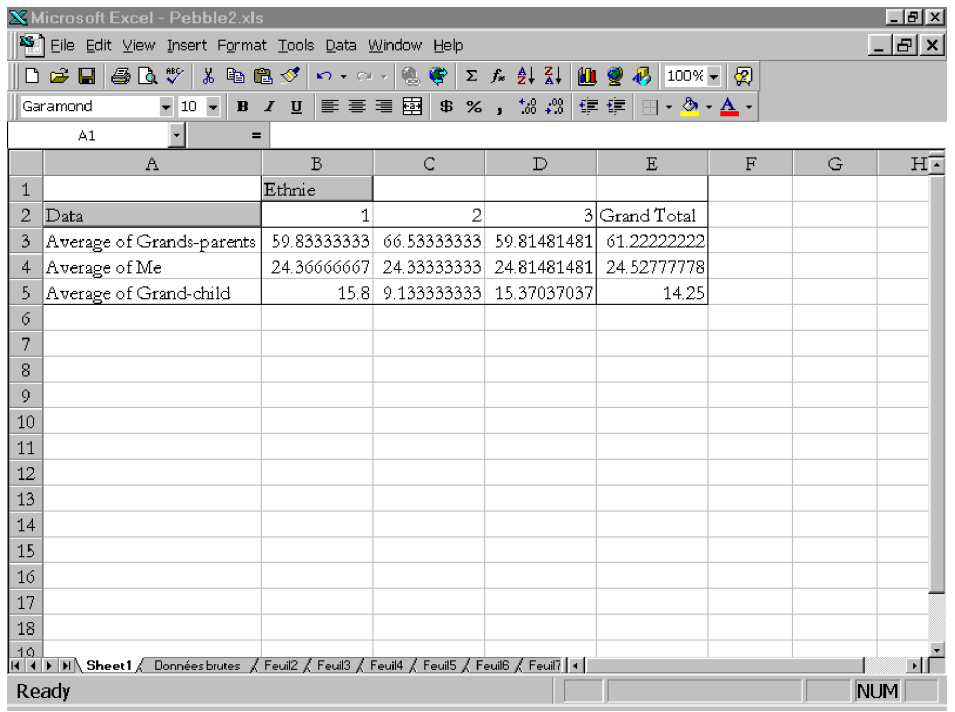

GAMBAR 30. Tabel MS Excel menggambarkan perbandingan distribusi akses antargenerasi terhadap sumber daya berdasarkan etnis.

\section{PANDUAN: PEMBAGIAN MANFAAT DI ANTARA PARA STAKEHOLDER}

Bagian ini dibagi menjadi tiga bagian. Bagian 1 menyediakan informasi cara membuat lembar isian dan memasukkan data. Bagian 2 menjelaskan cara melakukan analisis statistik sederhana terhadap data, terutama cara 
memeriksa distribusi data dan membuat tabel-tabel deskripsi sederhana. Bagi Anda yang puas dengan analisis sederhana, Anda dapat berhenti di Bagian 2. Bagian 3 ditujukan untuk mereka yang ingin melakukan analisis lanjutan, misalnya menguji signifikansi perbedaan persepsi di antara kelompokkelompok yang berbeda (berdasarkan etnis, umur, jender, dll.).

\section{a. Memasukkan data}

- Masukkan data menggunakan program lembar kerja, seperti Excel atau Lotus.

- Masukkan data demografi, misalnya kelompok pengguna, jender, umur, tingkat pendidikan, dll. dalam kolom-kolom sebelah kiri (Gambar 31, kolom-kolom A-F). Sedapat mungkin memasukkan data demografi dengan kode nomor. Jika Anda memiliki data kategori, seperti jender, tingkat pendidikan, dll., Anda perlu mengubahnya menjadi kode nomor ( misalnya, wanita $=0$, pria $=1$, dll.). Sangat penting untuk menyimpan lembar kode, sehingga Anda selalu mengetahui arti dari masing-masing kode. 


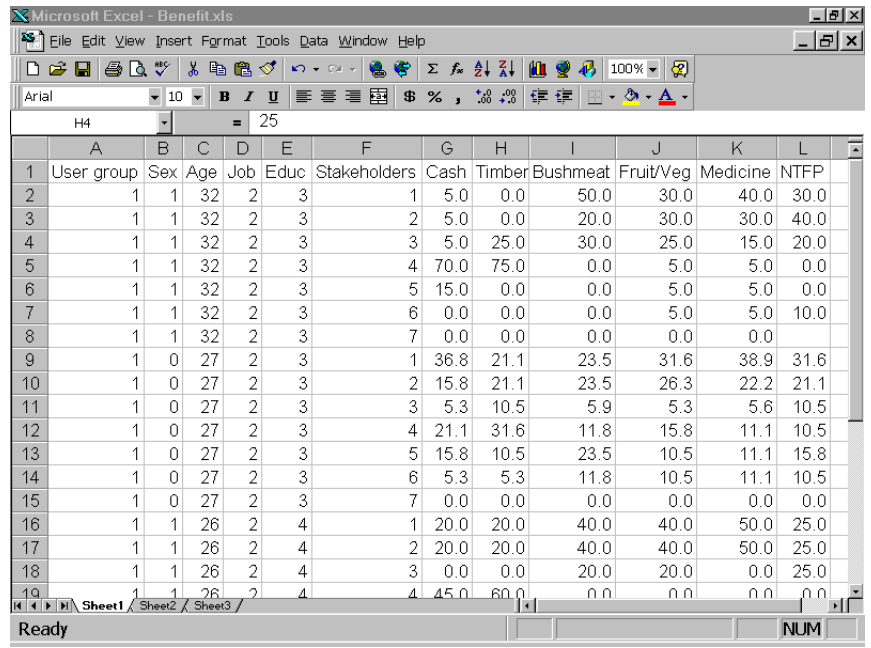

GAMBAR 31. Format lembar isian untuk data manfaat hutan.

- Gunakan satu baris untuk setiap stakeholder. Misalnya, dalam Gambar 31, kami memasukkan data dari Long Segar di mana 7 stakeholder kami identifikasi. Anda harus menggunakan baris 2-8 (7 baris) untuk responden 1, baris 9-15 (7 baris) untuk responden 2 dan seterusnya. Anda membutuhkan satu kolom untuk memasukkan kode stakeholder, ${ }^{39}$ menunjukkan bahwa baris tersebut milik stakeholder yang bersangkutan. Kolom F dalam contoh kami di atas berisi kode stakeholder.

${ }^{39}$ Masing-masing stakeholder diberi kode sebuah angka. Jika kami memiliki n stakeholder, kami dapat menentukan sebuah angka khusus untuk masing-masing stakeholder. Kami menyarankan Anda menggunakan kode stakeholder dengan cara yang mudah diingat sehingga lebih memudahkan analisis Anda. Misalnya, Anda mungkin menetapkan 1 untuk penduduk lokal, 2 untuk para kontraktor dan pedagang, dan 3 untuk pemerintah dan HPH. Cara penetapan kode Anda bergantung pada manfaat yang Anda rencanakan. 
- Dalam kolom berikutnya, Anda dapat memasukkan jumlah kerikil untuk masing-masing stakeholder yang diberikan oleh responden. Anda membutuhkan satu kolom untuk masing-masing manfaat. Dalam contoh di atas, kami menggunakan kolom $\mathrm{G}$ untuk uang, kolom $\mathrm{H}$ untuk kayu, dan seterusnya (Gambar 31).

- Setelah Anda selesai memasukkan semua data responden, jangan lupa menyimpan file ke dalam format Lotus 123 (*.wk1).

\section{b. Melakukan analisis data sederhana dengan metode SPSS $^{40}$}

Kami menggunakan SPSS (Paket Statistik untuk Ilmu Sosial) untuk menganalisis data.

- Membuka data Anda dapat membuka file Lotus 123 dalam layar SPSS. Gunakan pilihan read variable name. ${ }^{41}$

- Membuat label data

Gunakan lembar kode yang telah Anda buat ketika membuat kode data demografi ke dalam sebuah kode nomor untuk pelabelan data. Untuk membuat label data, tempatkan kursor pada kolom di mana data demografi berada. Di sini kami berikan sebuah contoh label data tingkat pendidikan.

${ }^{40}$ Kami juga membuat panduan bagi Anda yang ingin melakukan analisis sederhana menggunakan Excel (lihat Bagian c dalam bab ini).

${ }^{41}$ Dari pilihan menu bar SPSS, Anda dapat memilih File $\rightarrow$ Open, kemudian ubah tipe file ke Lotus (*.wk1) dan pilihlah file yang ingin Anda buka. Processor SPSS secara otomatis akan menanyakan Anda apakah Anda ingin membaca nama variabel atau tidak. Tentukan pilihan 'read the variable names'. 
Pilih dari menu:

Data

Define variable (Gambar 32).

Klik tombol Label (ditunjukkan oleh tanda panah). Anda akan diminta untuk memasukkan label (Gambar 33).

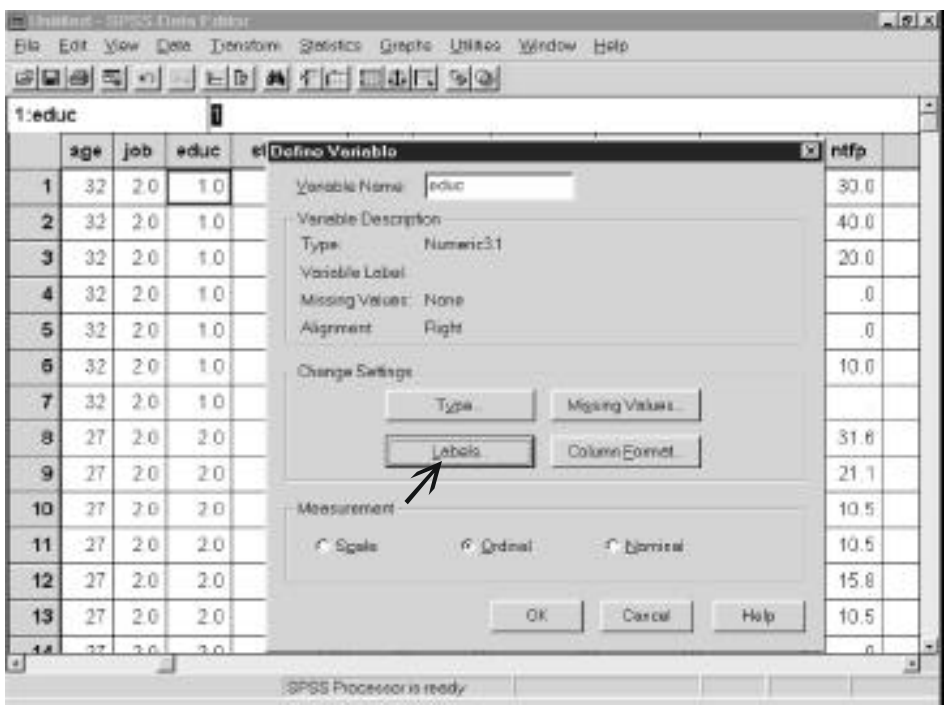

GAMBAR 32. Tombol label (data manfaat hutan).

Masukkan label demografi (misalnya, Sekolah Menengah Pertama, dalam contoh di atas) dan ketika Anda selesai, klik Continue.

Ikuti prosedur yang sama untuk data demografi yang lain. 


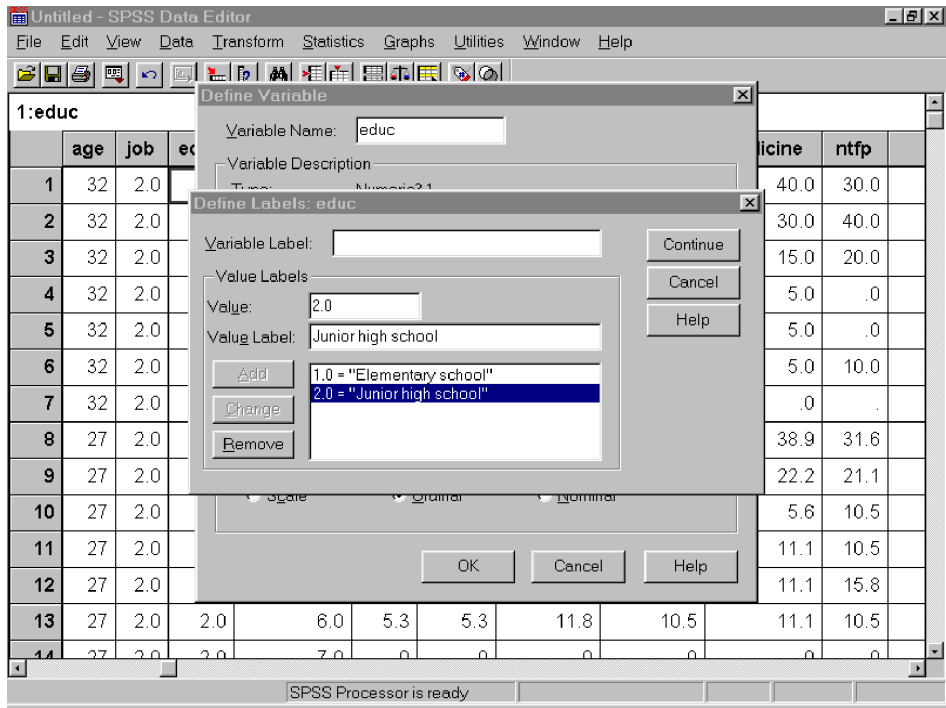

GAMBAR 33. Menentukan label untuk data tingkat pendidikan pada data manfaat hutan.

- Memeriksa distribusi data

Umumnya, kami menghitung mean/rata-rata untuk mengukur distribusi kerikil menurut para responden. Namun, penggunaan rata-rata memiliki beberapa kelemahan ketika data tidak tersebar secara simetris atau ketika tidak ada satu atau lebih pencilan. Jika hal ini terjadi, kami dapat menggunakan median/nilai tengah. Untuk memeriksa apakah data tersebar secara simetris atau tidak kami menggunakan sebuah diagram kotak garis. Dengan metode ini kami memeriksa data masing-masing manfaat secara terpisah, karena manfaat tersebut dipertimbangkan sebagai suatu variabel yang terpisah. Jika mayoritas manfaat didistribusikan secara tidak simetris, 
kami akan menggunakan median. Lain halnya, jika mayoritas manfaat didistribusikan secara simetris, kami harus menggunakan nilai rata-rata. Anda dapat membuat sebuah diagram kotak garis melalui petunjuk berikut ini:

$>$ Pilih dari menu

Graph

Boxplot

Pilih clustered dan summaries for separate variables (Gambar 34).

Klik tombol Define.

Masukkan semua manfaat sebagai variabel dan stake ${ }^{42}$ sebagai kategori sumbu mendatar axis (Gambar 35).

Anda akan memperoleh diagram kotak garis seperti yang ditunjukkan dalam Gambar 36. Garis hitam di dalam kotak menunjukkan letakmedian. Garis yang lebih tinggi dan lebih rendah dari masing-masing kotak berturut-turut menunjukkan letak kuartil ke-3 dan ke-1. Jika data didistribusikan secara simetris dan jika median hanya terletak di tengahtengah kotak, maka jarak dari kuartil ke-3 dan ke-1 kira-kira sama.

42 Stake merupakan nama kolom di mana kode stakeholder berada. Dalam contoh ini, kami gunakan stake, sebuah singkatan dari Stakeholder, untuk menamakan kolom. Tentunya Anda dapat menggunakan nama yang berbeda. 


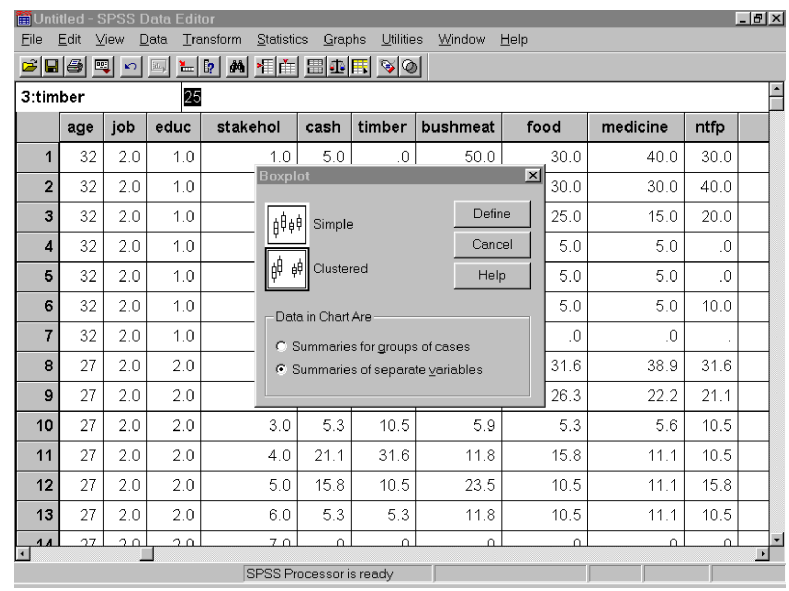

GAMBAR 34. Memilih tipe diagram kotak garis untuk data manfaat hutan.

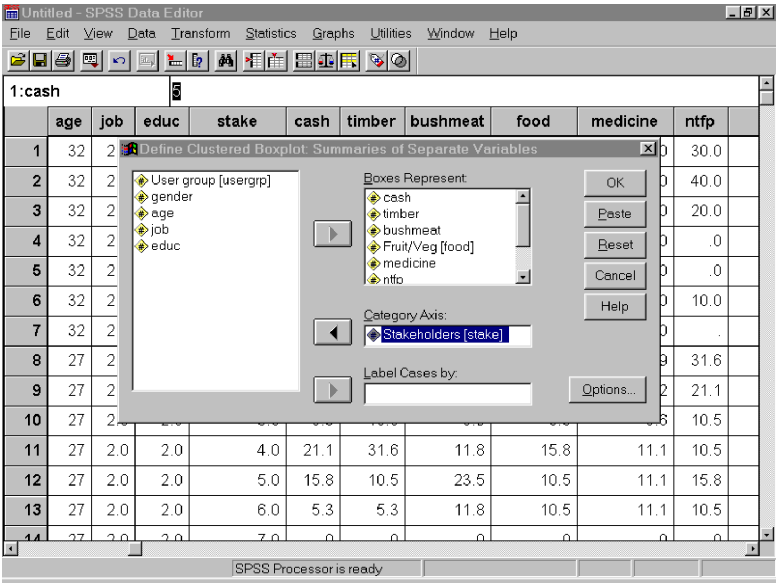

GAMBAR 35. Memilih variabel-variabel data manfaat hutan (untuk memeriksa distribusi data). 


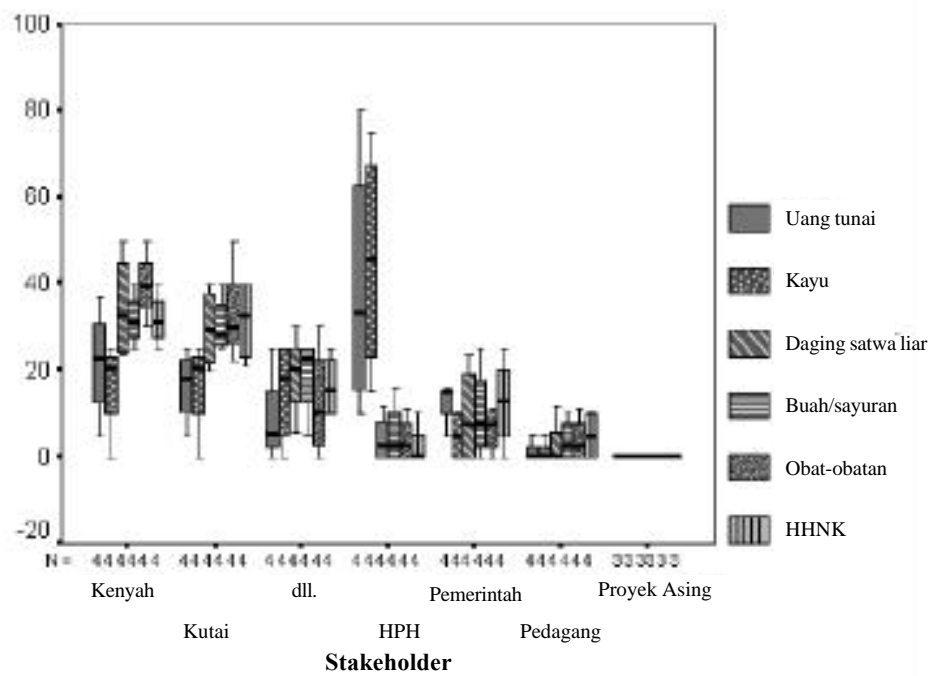

GAMBAR 36. Diagram kotak garis untuk data manfaat hutan.

> Jika distribusi data sangat tidak simetris atau ada beberapa pencilan (biasanya, ditunjukkan dengan tanda bintang atau lingkaran), kami sarankan Anda menggunakan median.

- Menghasilkan tabel untuk menggambarkan distribusi manfaat hutan, menurut semua responden

Pilih dari Menu:

Statistics

Custom Tables

$\underline{B}$ asic Tables

Letakkan semua manfaat dalam bagian summaries. Anda dapat melakukan ini dengan memilih nama kolom dan kemudian meletakkan tanda panah dalam kotak summaries (Gambar 37). 
Letakkan stake dalam subkelompok - dalam urutan menurun (Gambar 38).

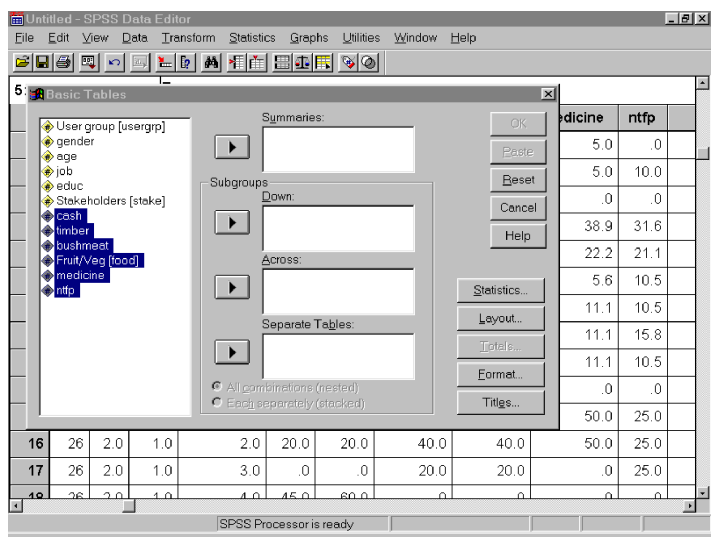

GAMBAR 37. Memilih variabel-variabel data manfaat hutan untuk diringkas (Tahap 1).

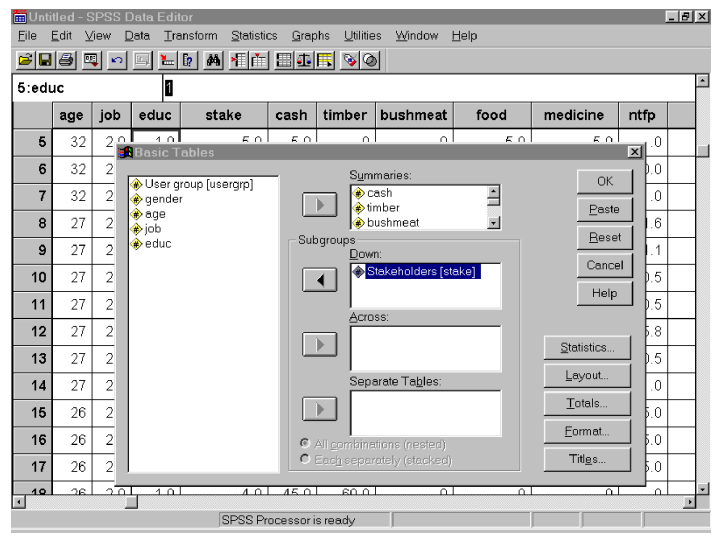

GAMBAR 38. Memilih variabel-variabel data manfaat hutan untuk diringkas (Tahap 2). 


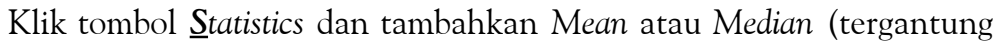
ukuran yang Anda ingin gunakan) sebagai kolom statistik.

Klik tombol OK, maka Anda akan memperoleh hasil (Gambar 39).

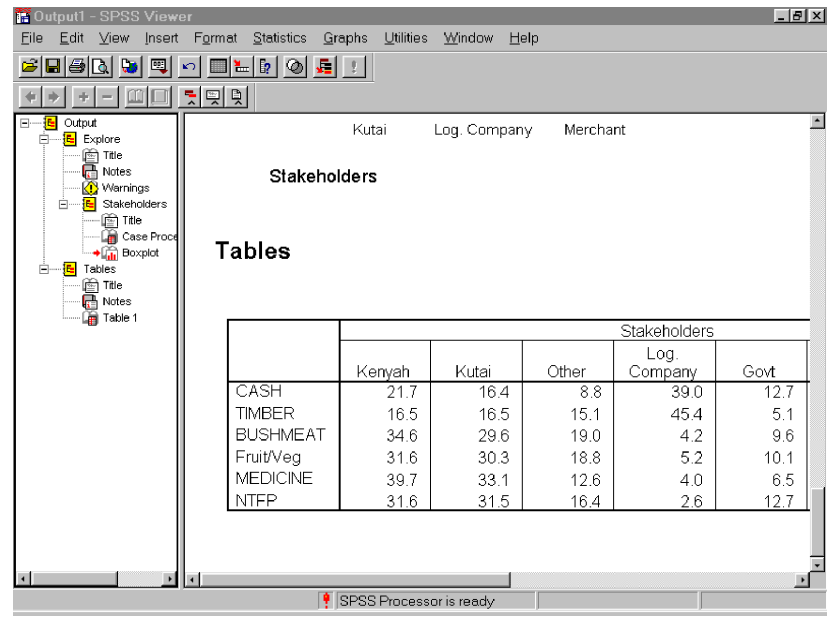

GAMBAR 39. Tabel SPSS menggambarkan distribusi manfaat hutan menurut semua responden.

c. Melakukan analisis sederhana menggunakan metode Excel

- Menghasilkan tabel untuk menggambarkan distribusi manfaat hutan, menurut semua responden

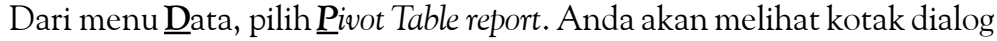
seperti yang ditunjukkan dalam Gambar 40 . 


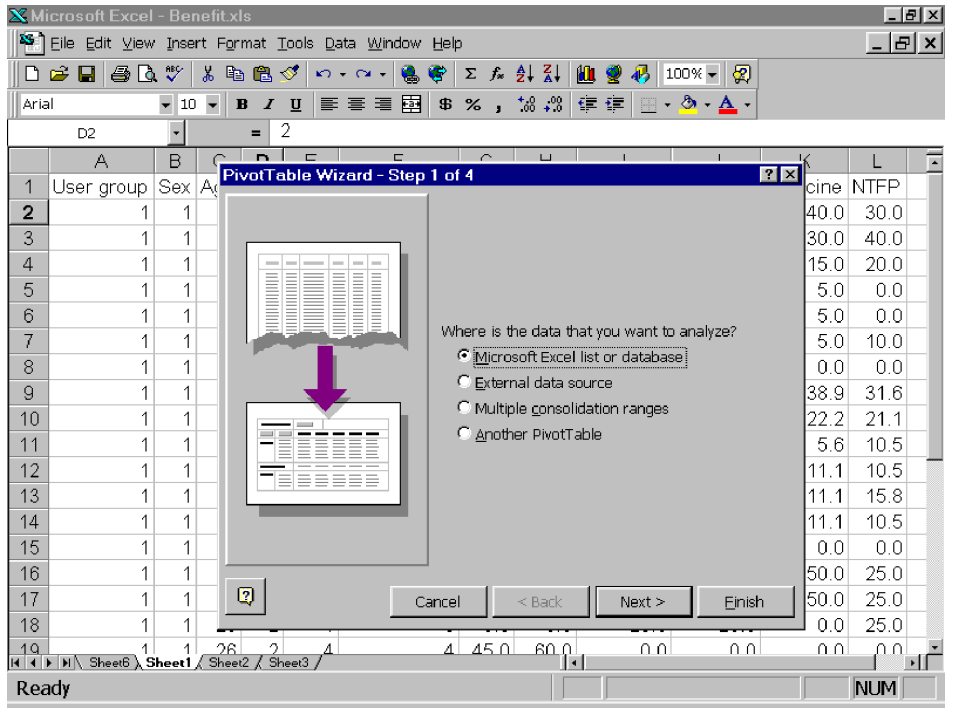

GAMBAR 40. Pola dasar tabel pivot (data manfaat hutan).

Klik tombol Next> dua kali, dan Anda akan melihat sebuah kotak dialog seperti yang ditunjukkan dalam Gambar 41. 


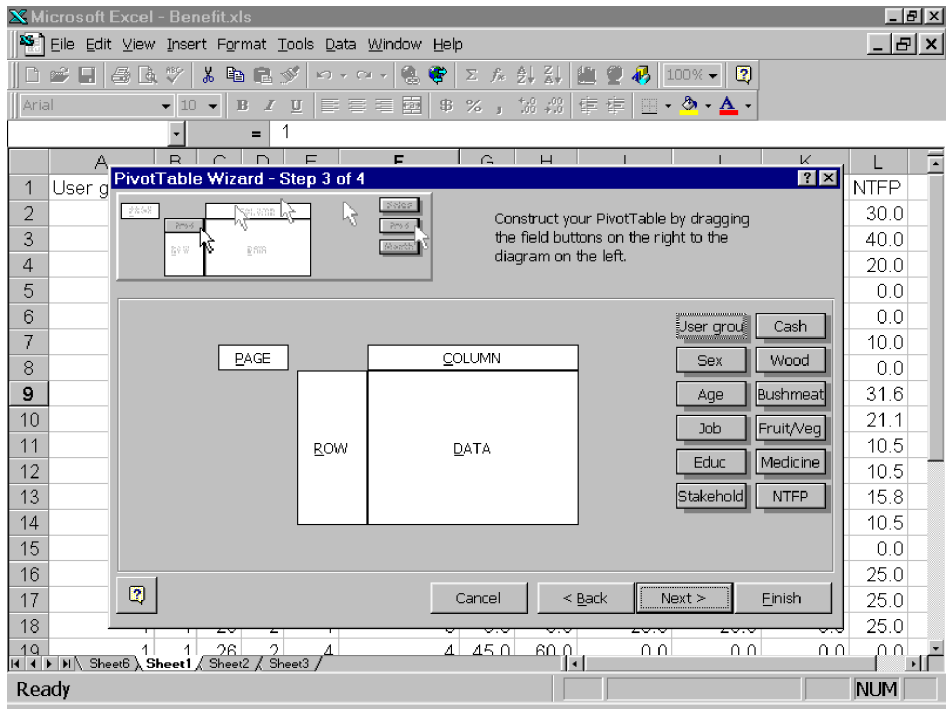

GAMBAR 41. Menyusun tabel pivot untuk analisis sederhana data manfaat hutan (Tahap 1).

> Tarik semua kolom di mana masing-masing manfaat berada, ke dalam ruang data dan stakeholder ke ruang kolom (Gambar 42). 


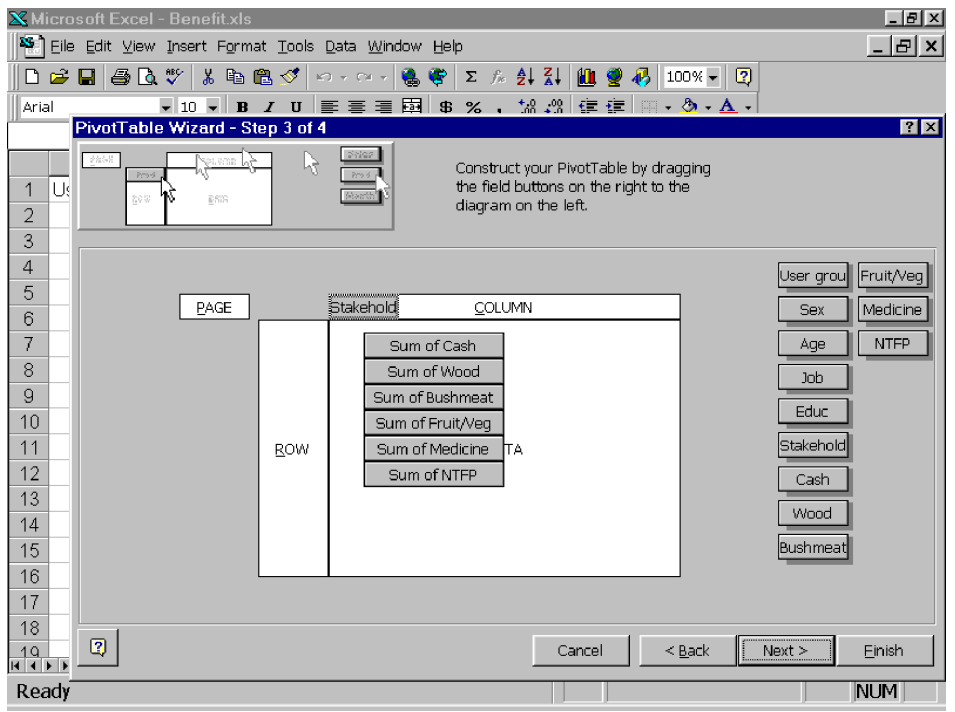

GAMBAR 42. Menyusun tabel pivot untuk analisis sederhana data manfaat hutan (Tahap 2).

> Jumlah (sum) merupakan statistik yang sudah diset. Statistik ini dapat Anda ubah dengan menekan tombol dan memilih statistik yang ingin Anda hitung (Gambar 43). 


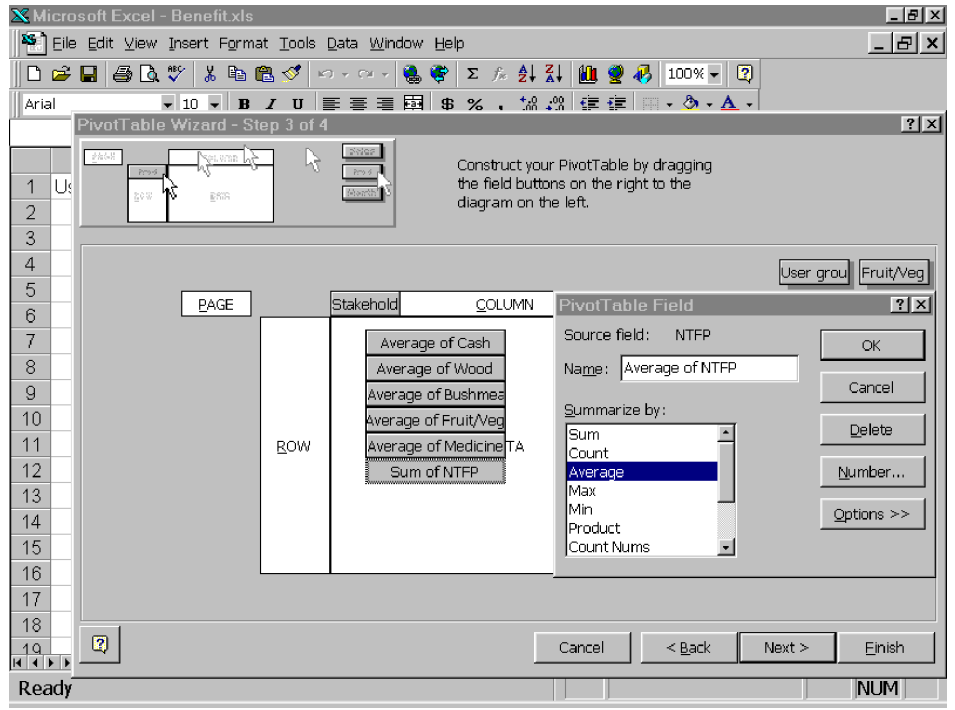

GAMBAR 43. Mengubah data statistik yang sudah diset pada data manfaat hutan.

Setelah Anda selesai mengubah statistik, Anda dapat mengklik tombol finish dan Anda akan memperoleh Tabel seperti yang ditunjukkan dalam Gambar 44. Jika Anda lebih menyukai jumlah digit yang lebih sedikit, Anda dapat menyesuaikan desimalnya. ${ }^{43}$

${ }^{43}$ Untuk menyesuaikan desimal, gunakan menu Format, pilih cells dan di bawah kategori pilih Numbers. Kemudian Anda dapat menyesuaikan desimal yang Anda inginkan dengan meningkatkan atau menurunkan desimal yang sudah dicantumkan (default $=2)$. 


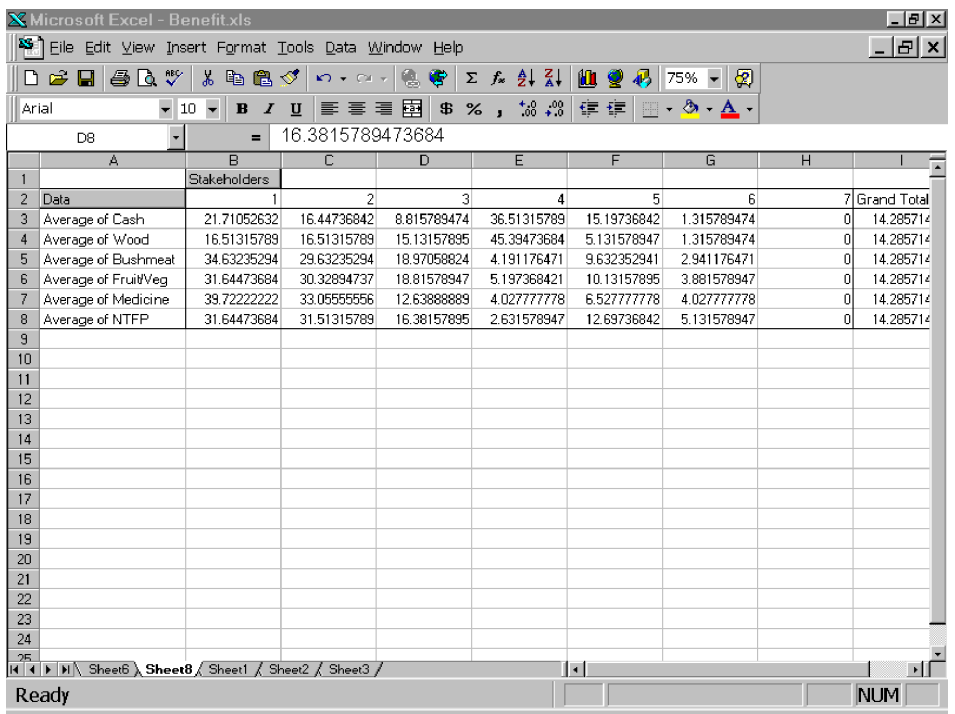

GAMBAR 44. Tabel MS Excel menggambarkan distribusi manfaat hutan menurut semua responden.

\section{d. Melakukan analisis data lanjutan dengan metode SPSS}

- Menghasilkan tabel untuk menggambarkan distribusi manfaat hutan, menurut subkelompok tertentu

Membandingkan subkelompok yang berbeda dengan masing-masing elemen demografi (etnis, jender, tingkat pendidikan, dll), berdasarkan persepsi mereka terhadap distribusi kerikil di antara para stakeholder. Untuk membandingkan persepsi subkelompok kami perlu mengetahui gambaran distribusi manfaat hutan di antara stakeholder, menurut masing-masing subkelompok. Anda 
dapat mengikuti petunjuk-petunjuk di bawah untuk memperoleh gambaran tersebut. Bayangkan Anda memiliki kelompok-kelompok responden dengan dua tingkat pendidikan, Sekolah Dasar dan Sekolah Menengah Pertama.

$>$ Pilih dari Menu

$\underline{\text { Data }}$

Select $\underline{\text { Cases }}$

Klik 'if condition is satisfied' (Gambar 45).

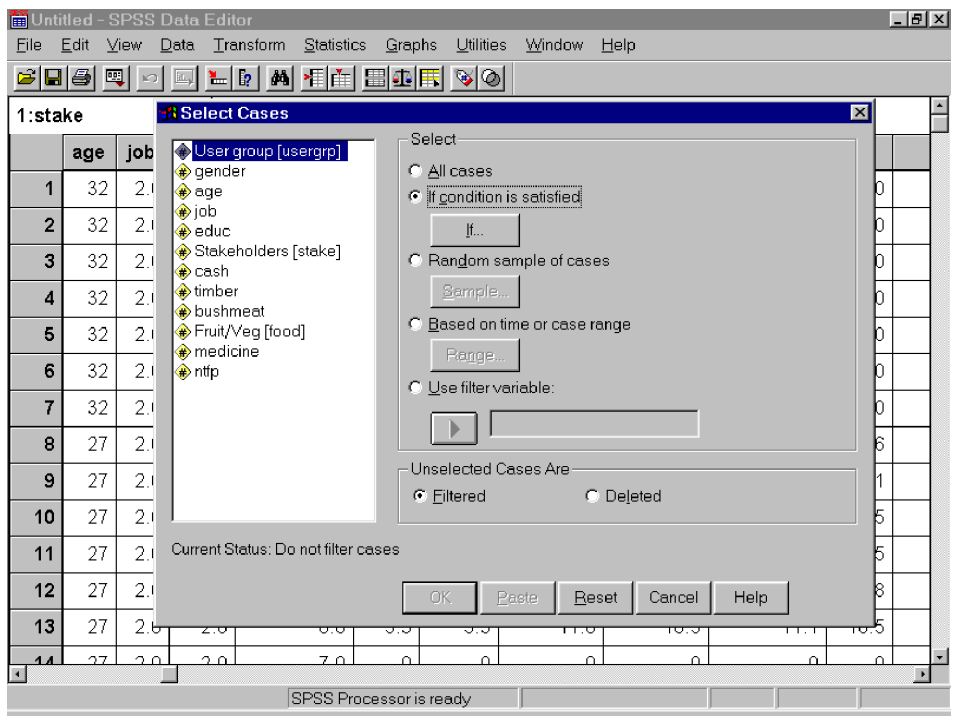

GAMBAR 45. Memilih kasus untuk subkelompok yang khusus pada data manfaat hutan. 
Klik tombol if.

Lihat lembar kode Anda untuk menentukan kode bagi Sekolah Dasar dan Sekolah Menengah Pertama (misalnya, Anda mungkin pernah di Sekolah Dasar $=1$, Sekolah Menengah Pertama $=2)$.

Ketik dalam kotak conditional (Gambar 46):

$e d u c=1$ (Anda akan menyaring data di mana nilai kolomeducate adalah $1)$.

Kemudian klik Continue dan OK (Gambar 46).

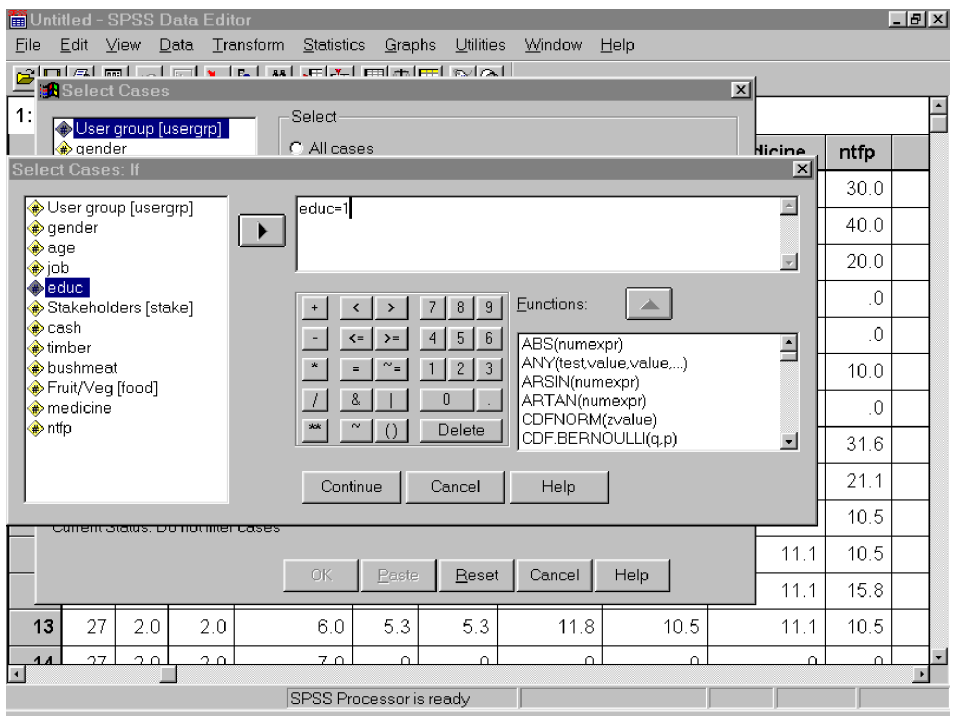

GAMBAR 46. Menyaring responden dengan tingkat pendidikan yang lebih rendah pada data manfaat hutan. 
Sekarang, jika Anda perhatikan layar SPSS, mungkin ada baris-baris dengan nilai yang tidak sama dengan 1 pada kolom educ. Responden dengan tingkat pendidikan Sekolah Menengah Pertama dan yang tidak termasuk dalam analisis berarti tidak diaktifkan. Status tidak aktif ini ditandai dengan sebuah garis diagonal pada nomor baris (lihat Gambar 47).

\begin{tabular}{|c|c|c|c|c|c|c|c|c|c|c|c|}
\hline \multicolumn{12}{|c|}{ 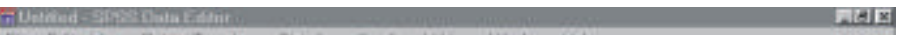 } \\
\hline Bie $\mathrm{t}$ & Ex Y & $m$ L & ath Inat & pm stones & or Greph & an Len & isodow & & & & \\
\hline \multicolumn{12}{|c|}{ B日) } \\
\hline \multicolumn{12}{|c|}{ 1:stakt } \\
\hline & age & 106 & edue & stake & $\cosh$ & timber & buahmeat & food & mediche & nttp & of \\
\hline 2 & 32 & 2.0 & 1.0 & 20 & 5.0 & 0 & 200 & 30.0 & 30.0 & 40.0 & \\
\hline $4^{3}$ & 32 & 2.0 & 1.0 & 8. 0 & 50 & 25.0 & 300 & 250 & 15.0 & 200 & \\
\hline 4 & 32 & 2.0 & 1.0 & 4.0 & $\$ 0.0$ & 750 & 0 & 50 & 50 & D. & \\
\hline 5 & 32 & 2.0 & 1.0 & 5.0 & 50 & 0 & 0 & 50 & 50 & 0 & \\
\hline 6 & 32 & 2.0 & 1.0 & 6,0 & 0 & 0 & 0 & 5.0 & 5.0 & 10.0 & \\
\hline 7 & 32 & 20 & 1.0 & 7.0 & 0 & 0 & 0 & 0 & 0 & 0 & \\
\hline 8 & 27 & 2.0 & 2.0 & 1.0 & 368 & 21.1 & 235 & 315 & 38.9 & 31.6 & \\
\hline 9 & 27 & 2.0 & 2.0 & 2.0 & 158 & 211 & 23.5 & 25.3 & 22.2 & 211 & \\
\hline 70 & 27 & 20 & 20 & 3.0 & 53 & 10.5 & 59 & 53 & 5.6 & 105 & \\
\hline$A 1$ & 27 & 2.0 & 2.0 & 4.0 & 21.1 & 31.6 & 118 & 15.8 & 111 & 105 & \\
\hline 92 & 27 & 2.0 & 2.0 & 50 & 15.8 & 105 & 235 & 10.5 & 12.1 & 15.8 & \\
\hline रत3 & 27 & 2.0 & 2.0 & 6.0 & 5.3 & 6.3 & 118 & 10.5 & 11.1 & 105 & \\
\hline 84 & 27 & 2.0 & 2.0 & 70 & 0 & 0 & 0 & 0 & 0 & 0 & \\
\hline \multirow[t]{2}{*}{$I^{2 k}$} & s. & 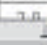 & $y=a$ & & 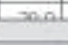 & $78 . a$ & san & an & & & \pm \\
\hline & & & & SPSBA & Ecenalt n & wasoby & & & Fhe & & \\
\hline
\end{tabular}

GAMBAR 47. Hasil seleksi (data manfaat hutan).

Lakukan langkah yang sama seperti dalam tahap 4 (Bagian b dalam bab ini), untuk memperoleh rata-rata distribusi kerikil menurut responden dengan tingkat pendidikan Sekolah Dasar (Gambar 48). 
Untuk memperoleh rata-rata distribusi kerikil menurut responden dengan tingkat pendidikan Sekolah Menengah Pertama, ubah saja the conditional expression menjadi:

$e d u c=2$

Kemudian lakukan langkah yang sama seperti dalam tahap 4 (Bagian b dalam bab ini).

Sekarang kita dapat membandingkan perbedaan distribusi manfaat hutan di antara dua stakeholder dengan tingkat pendidikan yang berbeda (Gambar 49).

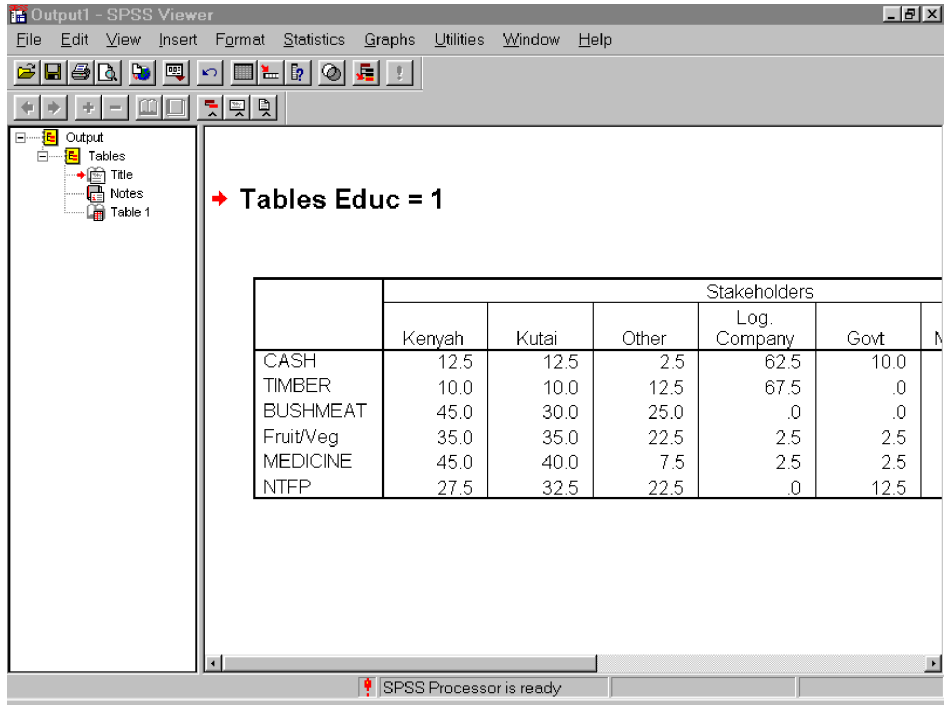

GAMBAR 48. Distribusi manfaat hutan di antara stakeholder menurut responden dengan tingkat pendidikan lebih rendah. 


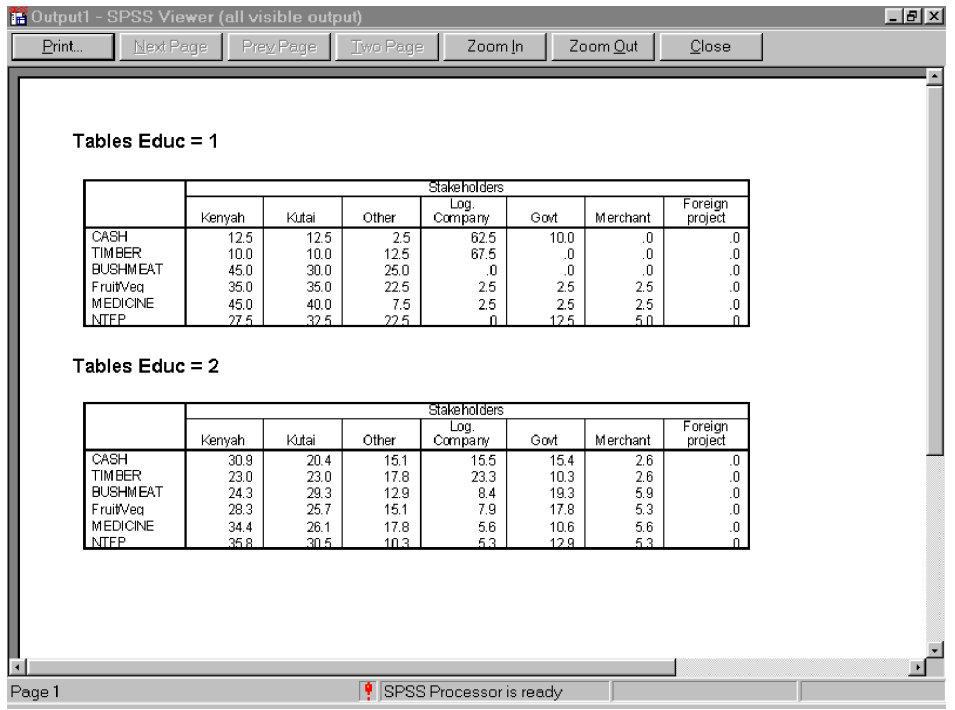

GAMBAR 49. Perbandingan distribusi manfaat hutan di antara stakeholder berdasarkan tingkat pendidikan.

Jika Anda memiliki lebih dari dua kategori data demografi (misalnya, tiga atau lebih tingkat pendidikan), Anda dapat melanjutkan langkah yang sama untuk memperoleh nilaimean/median distribusi kerikil di antara stakeholder untuk kategori yang lain.

- Menguji kesepakatan/ketidaksepakatan di antara kelompok-kelompok yang berbeda tentang distribusi manfaat hutan 
Anda dapat memeriksa ada tidaknya kesepakatan di antara subkelompok dengan masing-masing ciri-ciri demografi ${ }^{44}$ tentang banyaknya manfaat hutan yang dinikmati masing-masing stakeholder. Anda dapat melakukan analisis untuk masing-masing stakeholder. Pertama yang harus Anda lakukan adalah menyaring data hanya pada baris yang diseleksi sebagai stakeholder yang aktif dan baris lainnya tidak aktif (lihat di atas, cara menyaring data subkelompok). Dalam Gambar 50, kami menyaring data sehingga hanya baris Stake $=1$ (Kenyah) yang aktif sementara yang lain tidak aktif.

\section{$>$ Pilih dari menu}

\section{Statistics}

$\underline{\text { Nonparametric test }}$

$\underline{2}$ independent samples atau

K independent samples ${ }^{45}$

${ }^{44}$ Ciri-ciri demografi di sini dapat berupa jender, tingkat pendidikan, etnis, dll.

45 Jika Anda ingin menguji data hanya dengan dua kategori/dua kelompok, Anda harus memilih 2 Independent Sample dan kemudian gunakan uji Mann-Whitney. Jika Anda menggunakan lebih dari dua kategori, Anda harus memilih sampel K-independent, dan kemudian gunakan uji Kruskall-Wallis. 


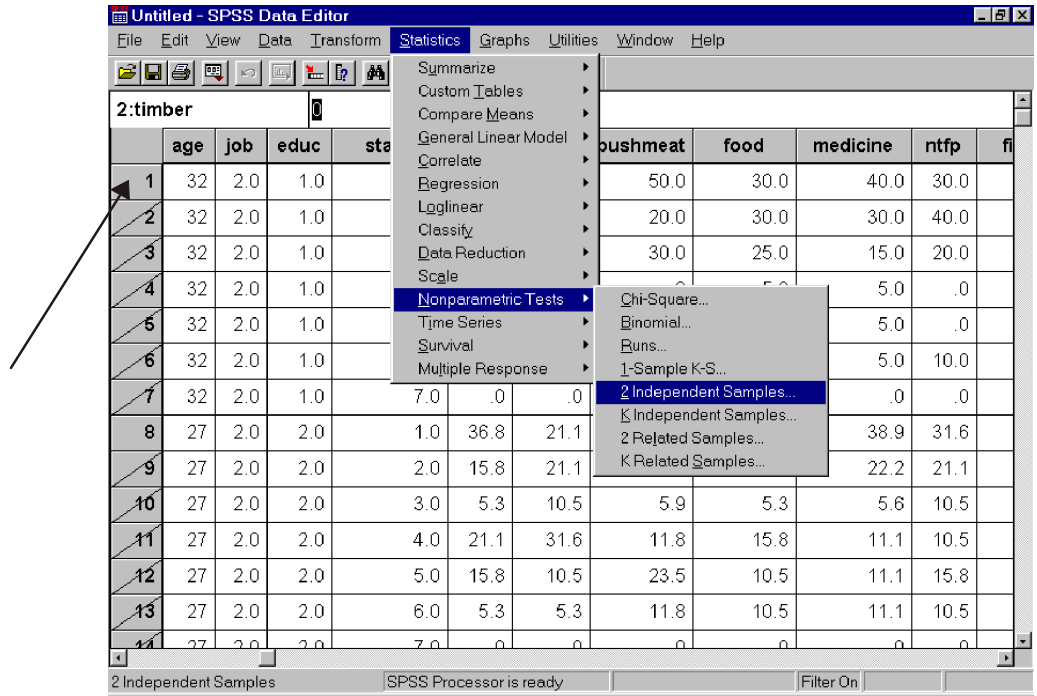

GAMBAR 50. Menyaring data untuk Kenyah dan memilih pengujian statistik (data manfaat hutan).

Letakkan test variable ${ }^{46}$ ke dalam kotak test variable list dan kelompokkan variabel ke dalam kotak grouping variable (Gambar 51). Kemudian Anda harus menetapkan nilai minimum dan maksimum dari grouping variable (Anda dapat melihat arti dari masing-masing kode pada lembar kode). Rincian dapat dilihat pada Gambar 52.

46 Test variable harus mengandung kolom data kerikil untuk masing-masing manfaat. Grouping variable merupakan kolom yang berisi ciri demografi subkelompok yang ingin kita bandingkan. 


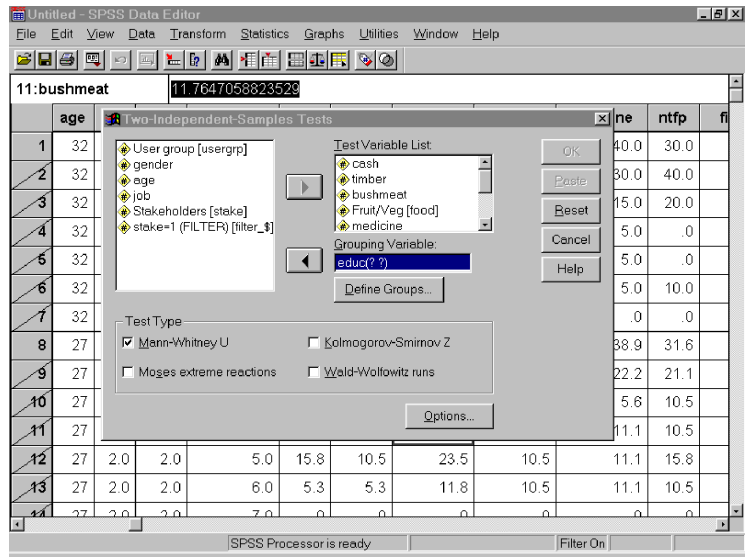

GAMBAR 51. Memilih test variable dan grouping variable (data manfaat hutan).

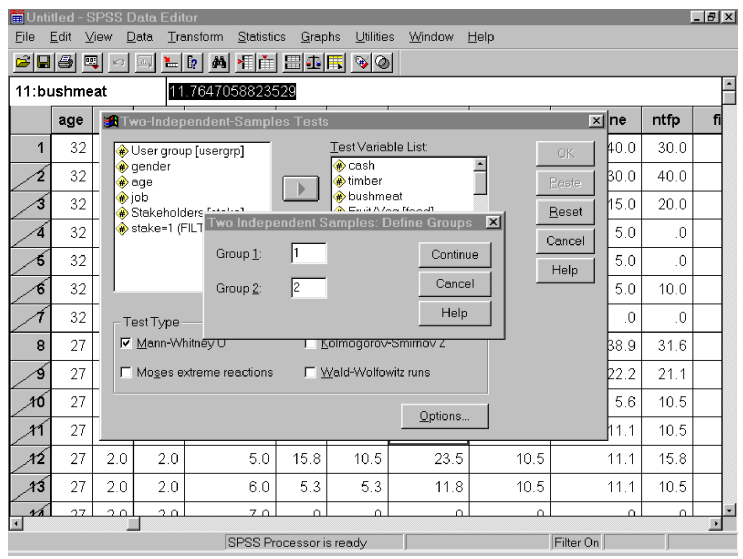

GAMBAR 52. Menentukan kisaran untuk grouping variable (data manfaat hutan). 
Klik Continue dan kemudian OK.

> Anda akan memperoleh hasil seperti yang ditunjukkan dalam Gambar 53. Pengujian akan dilakukan untuk masing-masing manfaat.

Pastikan untuk memeriksa signifikansi masing-masing pengujian.

$>$ Lihat nilai-p (ditandai oleh tanda panah). Jika nilai-p berada di bawah 0,05 , kita menolak hipotesis ketiadaan ${ }^{47}$ dan berkesimpulan ada ketidaksepakatan di antara kelompok-kelompok mengenai jumlah kerikil yang dimiliki oleh stakehoder yang dipilih (dalam hal ini, Kenyah). Jika nilai-p berada di atas 0,05 kami berkesimpulan ada kesepakatan di antara kelompok-kelompok yang berbeda.

Lakukan tahap yang sama untuk menguji kesepakatan/ketidaksepakatan mengenai jumlah manfaat hutan yang diberikan kepada stakeholder lain (misalnya, jika Anda ingin memeriksa kesepakatan/ketidaksepakatan di antara kelompok berdasarkan dengan jumlah kerikil yang diberikan kepada Kutai, Anda dapat menyeleksi data sehingga hanya baris dengan nilai Stake $=2$ (Kutai) yang aktif sementara yang lain tidak aktif).

${ }^{47}$ Di bawah masing-masing manfaat hutan, Hipotesis ketiadaan berarti: Bahwa semua subkelompok mendapatkan jumlah kerikil yang sama untuk stakeholder yang sedang diuji, dengan kata lain, semua subkelompok setuju mengenai jumlah manfaat hutan yang relevan, yang diberikan kepada stakeholder yang sedang diuji. 


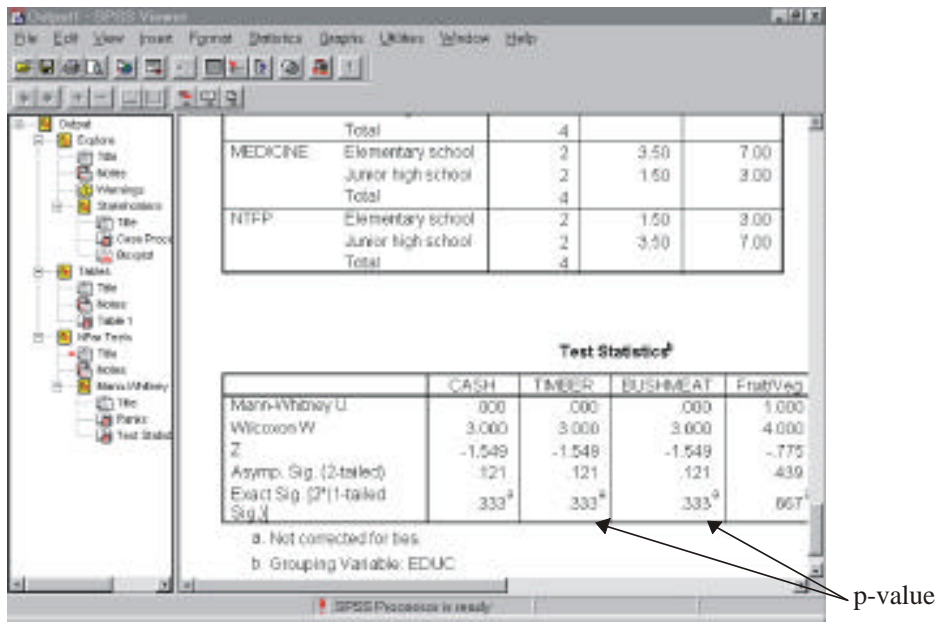

GAMBAR 53. Hasil pengujian statistik untuk Kenyah berdasarkan tingkat pendidikan (data manfaat hutan).

e. Melakukan analisis data lanjutan menggunakan metode Excel

- Manghasilkan tabel untuk menggambarkan distribusi manfaat hutan, menurut subkelompok tertentu

Anda dapat menggunakan prosedur yang sama untuk membuat tabel distribusi manfaat hutan menurut semua responden (Bagian c dalam bab ini). Perbedaannya hanya ketika Anda menyusun tabel pivot. Selain menarik semua manfaat ke ruang data dan stakeholder ke ruang kolom, Anda juga harus menarik kolom di mana ciri-ciri demografi ${ }^{48}$ tertentu berada dalam ruang baris (Gambar 54). Dalam contoh ini kami menggunakan tingkat pendidikan sebagai contoh.

${ }^{48}$ Ciri-ciri demografi di sini dapat berupa jender, tingkat pendidikan, umur, etnis, dll. 


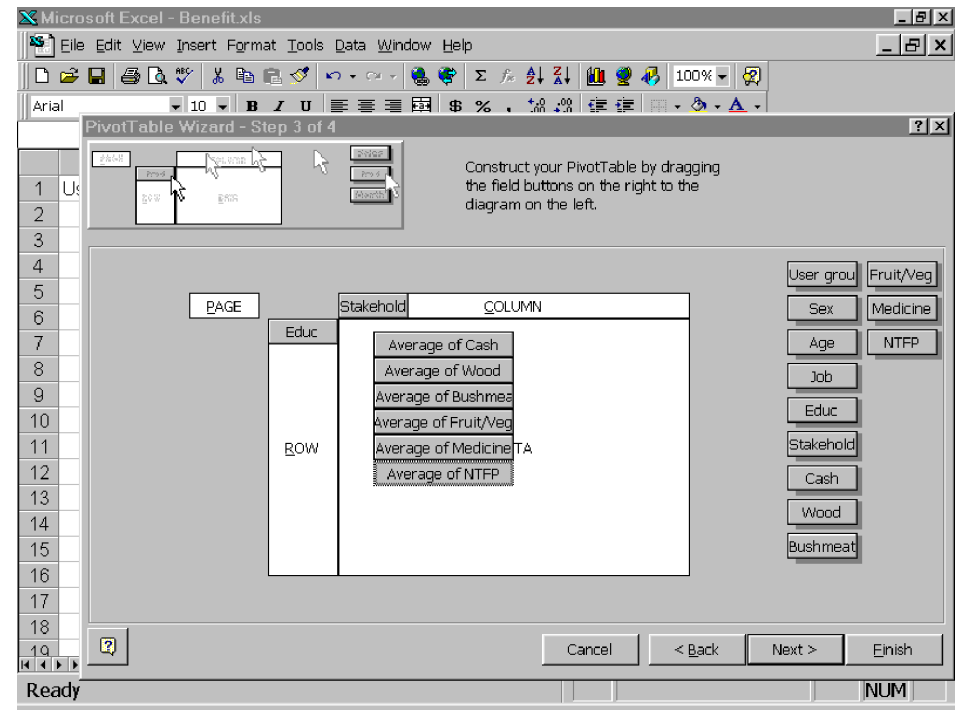

GAMBAR 54. Menyusun tabel pivot untuk analisis lanjutan data manfaat hutan.

> Klik tombol finish, maka Anda akan memperoleh hasilnya (Gambar 55). Perhatikan dua subtabel untuk masing-masing tingkat pendidikan (dalam contoh ini, seperti sebelumnya, tingkat pendidikan 1 artinya Sekolah Dasar, sementara tingkat pendidikan 2 artinya Sekolah Menengah Pertama). 


\begin{tabular}{|c|c|c|c|c|c|c|c|c|}
\hline \multicolumn{8}{|c|}{ X Micros oft Excel - Benefit.xls } & - \\
\hline \multicolumn{8}{|c|}{ |25 Elle Edit View Insert Format Iools Data Window Help } & 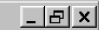 \\
\hline \multicolumn{9}{|c|}{ 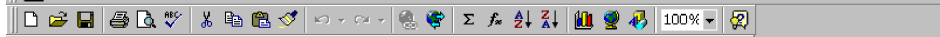 } \\
\hline \multicolumn{9}{|c|}{ Arial } \\
\hline \multicolumn{9}{|c|}{$A 3$} \\
\hline & A & \multicolumn{2}{|r|}{ B } & C & $\mathrm{D}$ & \multirow[t]{2}{*}{$E$} & \multirow[t]{2}{*}{$F$} & \multirow[t]{2}{*}{$\mathrm{G}:$} \\
\hline & & & & Stakeholders & & & & \\
\hline 2 & Educ & Data & & 1 & 2 & 3 & \multicolumn{2}{|l|}{4} \\
\hline 3 & & \multicolumn{2}{|c|}{ Average of Cash } & 20.92105263 & 10.39473684 & 5.131578947 & 79 & 15.3947: \\
\hline 4 & & \multicolumn{2}{|c|}{ Average of Wood } & 10.52631579 & 10.52631579 & 17.76315789 & 53.28947368 & 5.26315 \\
\hline 5 & & \multicolumn{2}{|c|}{ Average of Bushmeat } & 36.76470588 & 21.76470588 & 17.94117647 & 5.882352941 & 11.7647 \\
\hline 6 & & \multicolumn{2}{|c|}{ Average of Fruit/Veg } & $\mid \begin{array}{ll}30.78947368 \\
\end{array}$ & 28.15789474 & 15.13157895 & 10.39473684 & 7.76315 \\
\hline 7 & & \multicolumn{2}{|c|}{ Average of Medicine } & 39.44444444 & 26.11111111 & 10.27777778 & 8.055555556 & 8.05555 \\
\hline 8 & & \multicolumn{2}{|c|}{ Average of NTFP } & 30.78947368 & 30.52631579 & 15.26315789 & 5.263157895 & 7.89473 \\
\hline 9 & & \multicolumn{2}{|c|}{ Average of Cash } & 22.5 & 22.5 & 12.5 & 27.5 & \\
\hline 10 & & \multicolumn{2}{|c|}{ Average of Wood } & 22.5 & 22.5 & 12.5 & 37.5 & \\
\hline 11 & & \multicolumn{2}{|c|}{ Average of Bushmeat } & 32.5 & 37.5 & 20 & 2.5 & \\
\hline 12 & & \multicolumn{2}{|c|}{ Average of Fruit/Veg } & 32.5 & 32.5 & 22.5 & 0 & \\
\hline 13 & & Aver & age of Medicine & 40 & 40 & 15 & 0 & \\
\hline 14 & & Aver & age of NTFP & 32.5 & 32.5 & 17.5 & 0 & \\
\hline 15 & Total Aver & age 0 & Cash & 21.71052632 & 16.44736842 & 8.815789474 & 36.51315789 & $15.1973 \mathrm{t}$ \\
\hline 16 & Total Aver & age o & Wood & 16.51315789 & 16.51315789 & 15.13157895 & 45.39473684 & 5.13157 \\
\hline 17 & Total Aver & age 0 & Bushmeat & 34.63235294 & 29.63235294 & 18.97058824 & 4.191176471 & 9.63235 \\
\hline 18 & Total Aver & age 0 & Fruit/Neg & 31.64473684 & 30.32894737 & 18.81578947 & 5.197368421 & 10.1315 \\
\hline 119 & $\begin{array}{l}\text { Total Aver } \\
\text { - Al Sheoes }\end{array}$ & & $\begin{array}{l}\text { Morlicine } \\
\lambda \text { Sheet9/Sh }\end{array}$ & 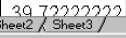 & 320555555. & 17 628888889 & $\Delta \cap 077777778$ & 6 5 5777\% \\
\hline $\operatorname{Re}$ & & & & & & Sum $=686.71$ & 42857 & NUM \\
\hline
\end{tabular}

GAMBAR 55. Tabel MS Excel menggambarkan perbandingan distribusi manfaat hutan berdasarkan tingkat pendidikan. 


\section{ANALISIS METODE-METODE UNTUK HAK DAN KEMAMPUAN MENGELOLA HUTAN}

Bagian ini berisi panduan untuk menganalisis hasil-hasil dari metode distribusi kerikil yang berguna dalam penilaian hak dan kemampuan mengelola hutan secara bersama dan adil. Bagian ini dibagi menjadi tiga bagian. Bagian 1 menyediakan informasi cara membuat lembar isian dan memasukkan data. Bagian 2 menjelaskan cara melakukan analisis statistik sederhana, terutama cara memeriksa distribusi data dan cara membuat tabel deskripsi sederhana. Bagi Anda yang puas dengan analisis sederhana, Anda dapat berhenti di Bagian 2. Bagian 3 ditujukan bagi mereka yang ingin melakukan analisis lanjutan, seperti menguji signifikansi perbedaan persepsi di antara kelompok-kelompok yang berbeda dengan masing-masing ciri demografi (berdasarkan etnis, umur, jender, dll.).

\section{PANDUAN HAK MENGELOLA HUTAN}

\section{a. Memasukkan data}

- Memasukkan data menggunakan sebuah program lembar kerja seperti Excel atau Lotus.

- Memasukkan data demografi, misalnya kelompok pengguna, jender, umur, tingkat pendidikan, dll. dalam kolom-kolom sebelah kiri (seperti ditunjukkan dalam Gambar 56, kolom-kolom A-F). Sedapat mungkin memasukkan data demografi dengan kode nomor. Jika Anda memiliki data kategori, seperti jender, tingkat pendidikan, dll., Anda perlu mengubahnya menjadi kode nomor (misalnya, wanita $=0$, pria $=1$, dll.) Sangat penting untuk menyimpan lembar kode, sehingga Anda selalu 
mengetahui arti dari masing-masing kode. Anda akan memerlukan lembar arti kode ini saat melakukan analisis.

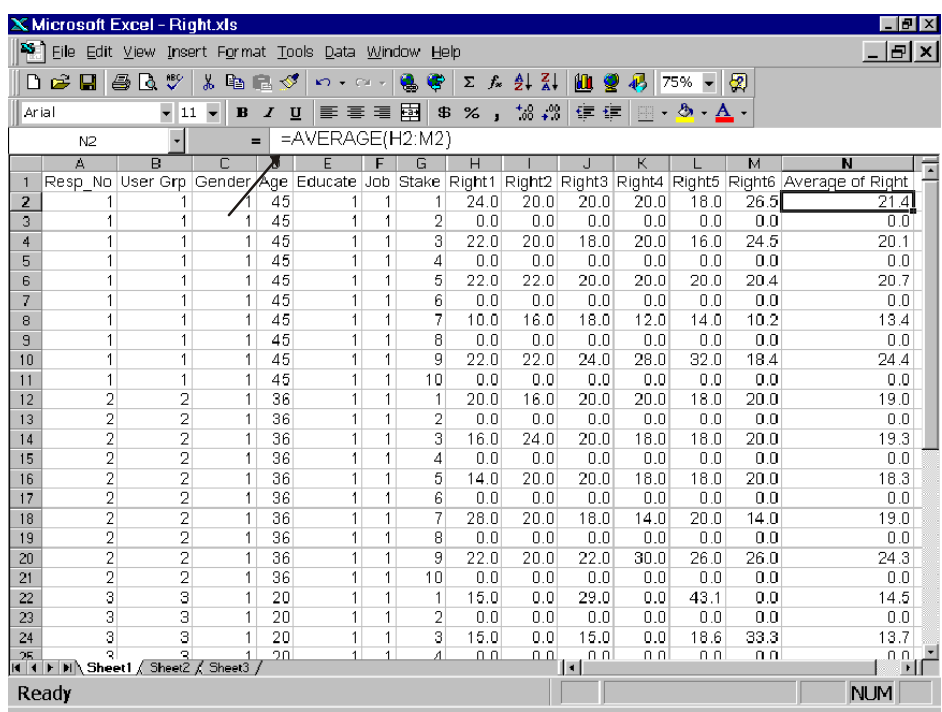

GAMBAR 56. Format lembar isian untuk data hak mengelola.

- Jika Anda memiliki jumlah (n) tertentu stakeholder, Anda harus menggunakan $\mathrm{n}$ buah baris untuk masing-masing responden atau, dengan kata lain, satu baris untuk masing-masing stakeholder. Misalnya, dalam Gambar 56, kami memasukkan data dari Bulungan ${ }^{49}$ di mana 10

${ }^{49}$ Bulungan merupakan salah satu lokasi penelitian CIFOR, berlokasi di Kalimatan Timur, Indonesia. 
stakeholder kami identifikasi. Anda harus menggunakan baris 2-11 (10 baris) untuk responden 1, baris 12-21 (10 baris) untuk responden 2 dan seterusnya. Anda membutuhkan satu kolom untuk memasukkan kode stakeholder ${ }^{50}$, menunjukkan bahwa baris tersebut milik stakeholder yang bersangkutan. Kolom G dalam contoh kami di atas berisi kode stakeholder.

- Dalam enam kolom berikutnya, Anda dapat memasukkan jumlah kerikil untuk masing-masing stakeholder yang diberikan oleh responden. Kolom $\mathrm{H}$ untuk Hak 1 (Menentukan/melindungi Batas-batas), Kolom I untuk Hak 2 (Meningkatkan/menerapkan berbagai Peraturan) dan seterusnya.

- Gunakan kolom terakhir di sebelah kanan (Hak 6) untuk memperoleh rata-rata hak dari masing-masing stakeholder. Untuk memperoleh ratarata, secara sederhana gunakan fungsi ${ }^{51}$ AVERAGE di Excel. Misalnya, kolom N2 dalam Gambar 1 merupakan rata-rata dari kolom H2 hingga kolom M2 (ditunjukkan oleh tanda panah).

- Setelah Anda selesai memasukkan semua data responden, jangan lupa menyimpan file ke dalam format Lotus 123 (*.wk1).

${ }^{50}$ Masing-masing stakeholder diberi kode sebuah angka. Jika kami memiliki n stakeholder, kami dapat menentukan sebuah angka khusus untuk masing-masing stakeholder. Kami menyarankan Anda menggunakan kode stakeholder dengan cara yang mudah diingat sehingga lebih memudahkan analisis Anda. Misalnya, Anda mungkin menetapkan 1 untuk penduduk lokal, 2 untuk para kontraktor dan pedagang, dan 3 untuk pemerintah dan $\mathrm{HPH}$. Cara penetapan kode Anda bergantung pada manfaat yang Anda rencanakan.

${ }^{51}$ Untuk menggunakan fungsi AVERAGE, ketik =AVERAGE (Start Cell:End Cell). Mulai dari kolom pertama sampai terakhir dirata-ratakan. Misalnya, dalam Gambar 1, kolom N2 merupakan rata-rata $\mathrm{H} 2$ hingga M2 (ditunjukkan oleh tanda panah). 


\section{b. Melakukan analisis data sederhana dengan metode SPSS ${ }^{52}$}

Kami menggunakan SPSS (Paket Statistik untuk Ilmu Sosial) untuk menganalisis data.

- Membuka data

Anda dapat membuka file Lotus 123 dalam layar SPSS. Gunakan pilihan read variable name..$^{53}$

- Membuat label data

Gunakan lembar kode yang telah Anda buat ketika membuat kode data demografi ke dalam kode nomor untuk pelabelan data. Untuk membuat label data, tempatkan kursor pada kolom di mana data demografi ada. Di sini kami berikan sebuah contoh label data tingkat pendidikan.

Pilih dari menu

\section{$\underline{\text { Data }}$}

Define variable (Gambar 57).

Klik tombol Label (ditunjukkan oleh tanda panah). Anda akan diminta untuk memasukkan label (Gambar 58).

52 Kami juga membuat panduan bagi Anda yang ingin melakukan analisis sederhana menggunakan Excel (lihat Bagian c dalam bab ini).

53 Dari pilihan menu bar SPSS, Anda dapat memilih File $\rightarrow$ Open, kemudian ubah tipe file ke Lotus (*.wk1) dan pilihlah file yang ingin Anda buka. Processor SPSS secara otomatis akan menanyakan Anda apakah Anda ingin membaca nama variabel atau tidak. Tentukan pilihan 'read the variable names. 


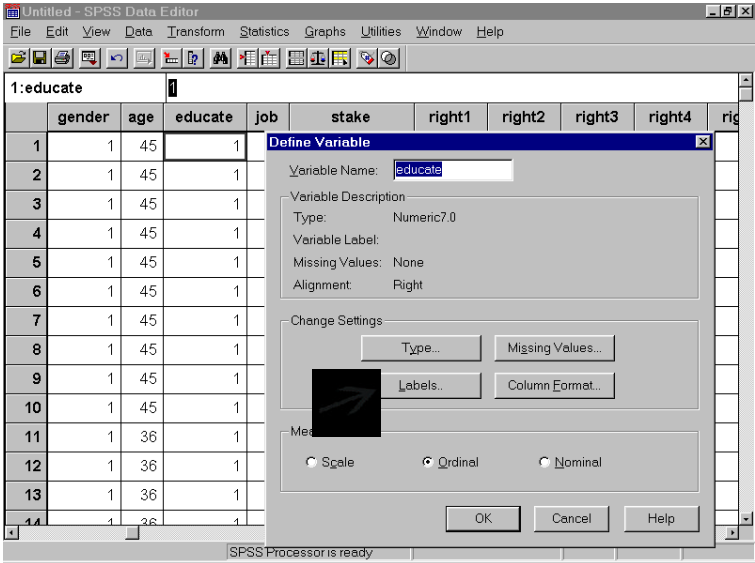

GAMBAR 57. Tombol label (data hak mengelola).

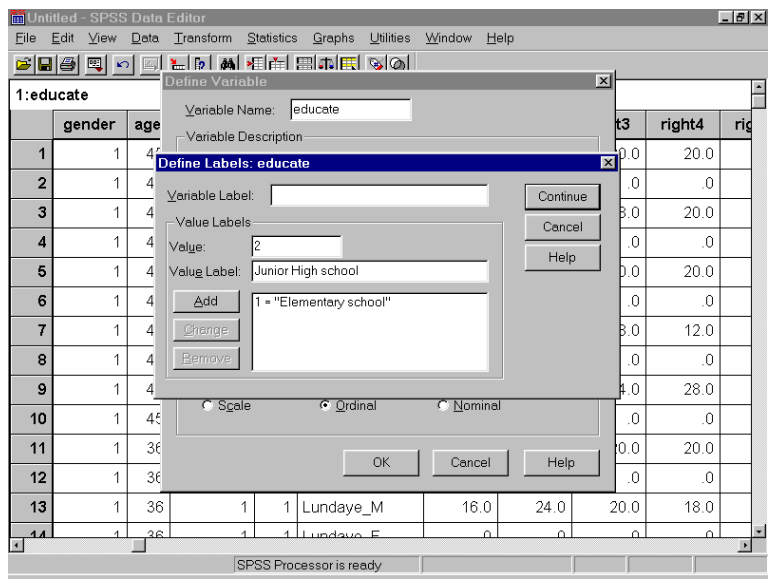

GAMBAR 58. Menentukan label untuk data tingkat pendidikan (data hak mengelola). 
Masukkan label demografi (misalnya, Sekolah Menengah Pertama, dalam contoh di atas) dan ketika Anda selesai, klik Continue.

$>$ Ikuti prosedur yang sama untuk data demografi yang lain.

- Memeriksa distribusi data

Umumnya, kami menghitung mean/rata-rata untuk mengukur distribusi kerikil menurut para responden. Namun, penggunaan rata-rata memiliki beberapa kelemahan ketika data tidak tersebar secara simetris atau ketika tidak ada satu atau lebih pencilan. Jika hal ini terjadi, kami dapat menggunakan median/nilai tengah. Untuk memeriksa apakah data tersebar secara simetris atau tidak kami menggunakan sebuah diagram kotak garis.

Anda dapat membuat sebuah diagram kotak garis melalui petunjuk berikut ini:

$>$ Pilih dari menu

\section{Graph}

Boxplot

Pilih simple dan summaries for groups of cases (Gambar 59).

$>$ Klik tombol Define.

> Masukkan average of right dan stake sebagai kategori sumbu mendatar (Gambar 60).

$>$ Anda akan memperoleh diagram kotak garis seperti yang ditunjukkan dalam Gambar 61. Garis hitam di dalam kotak menunjukkan letakmedian. Garis yang lebih tinggi dan lebih rendah dari masing-masing kotak berturut-turut menunjukkan letak kuartil ke-3 dan ke-1. Jika data didistribusikan secara simetris dan jika median hanya terletak di tengahtengah kotak, maka jarak dari kuartil ke-3 dan kuartil ke-1 kira-kira sama. 


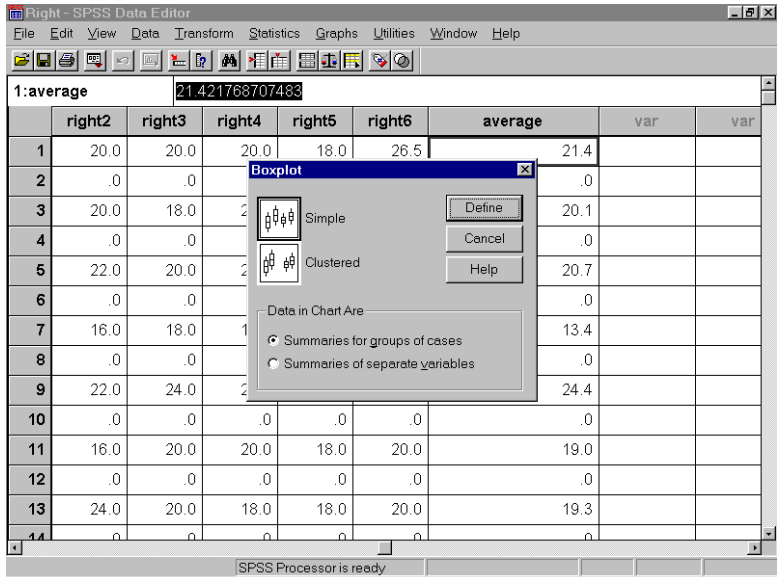

GAMBAR 59. Memilih tipe diagram kotak garis untuk data hak mengelola.

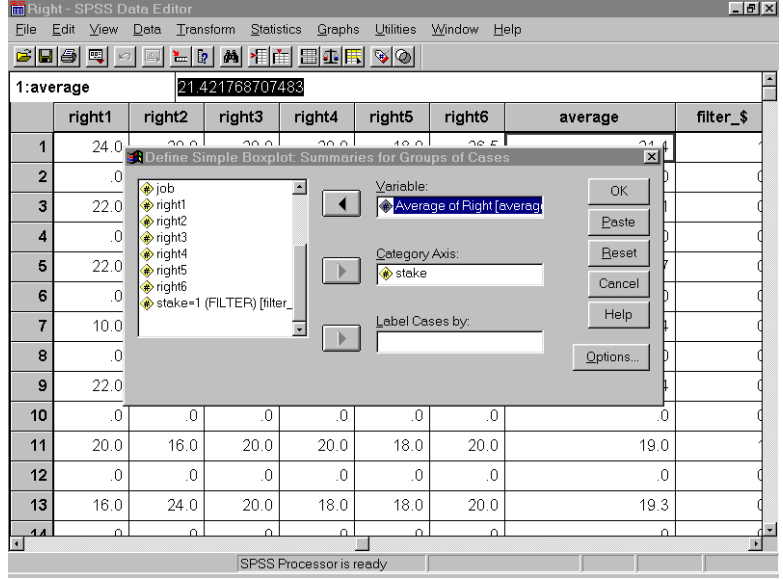

GAMBAR 60. Memilih variabel-variabel data hak mengelola (untuk memeriksa distribusi data). 


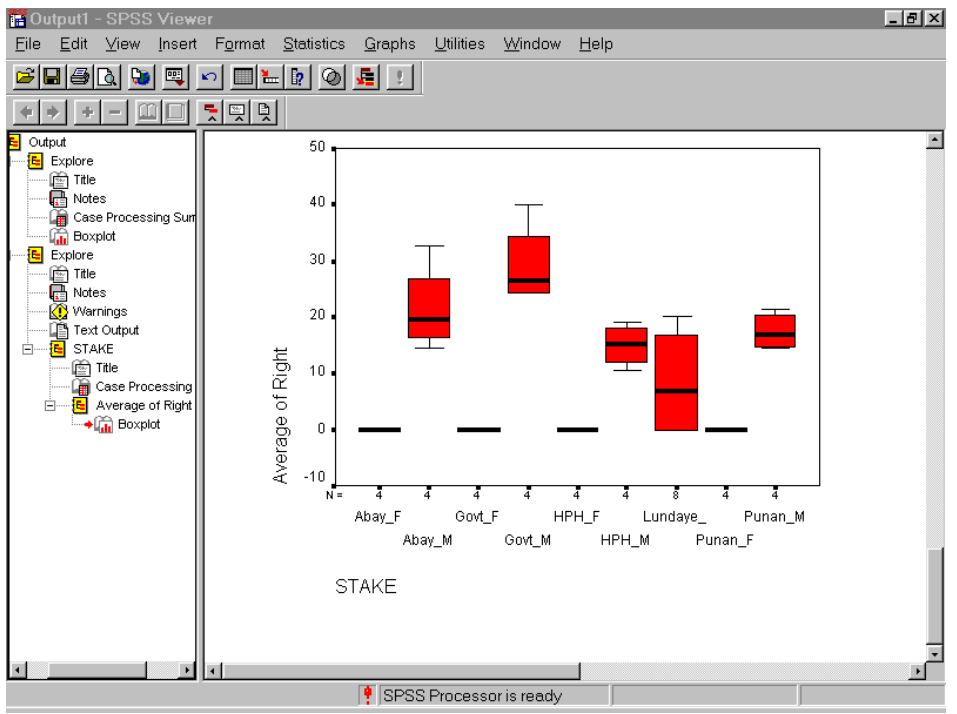

GAMBAR 61. Diagram kotak garis untuk data hak mengelola.

> Jika distribusi data sangat tidak simetris atau ada beberapa pencilan (biasanya, ditunjukkan dengan tanda bintang atau lingkaran), kami sarankan Anda menggunakan median.

- Menghasilkan tabel untuk menggambarkan distribusi kerikil menurut semua responden

Pilih dari Menu

Statistics

Custom Tables

$\underline{B}$ asic Tables 
Letakkan average of right dalam kotak summaries. Anda dapat melakukan ini dengan memilih nama kolom dan kemudian mengklik tanda panah dalam kotak summaries (Gambar 62).

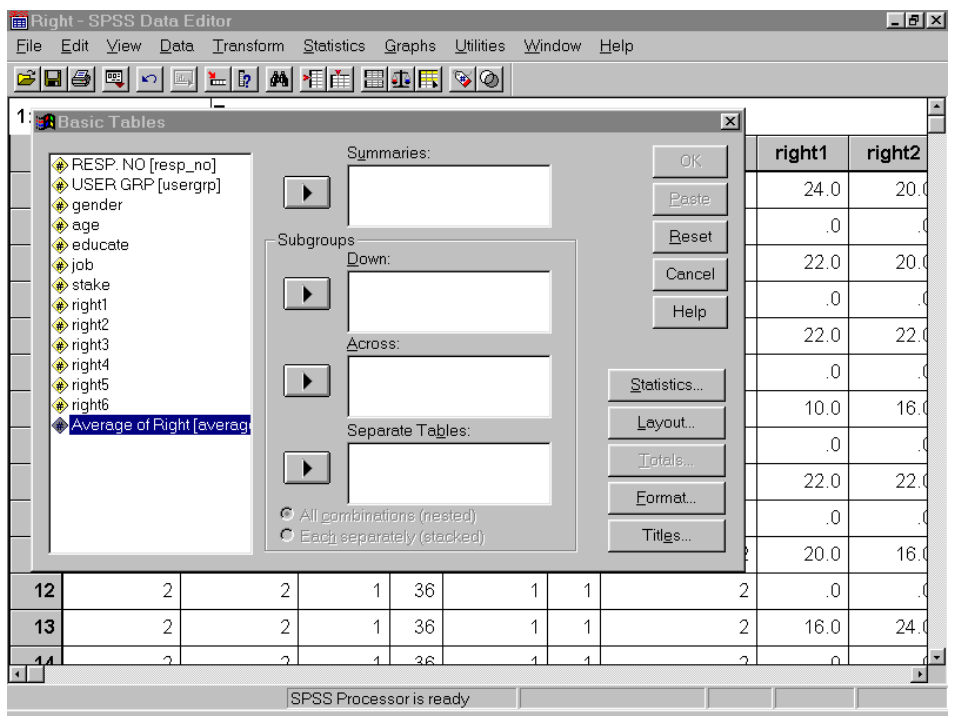

GAMBAR 62. Memilih variabel-variabel data hak mengelola untuk diringkas (Tahap 1).

Letakkan stake dalam subkelompok dalam urutan menurun (Gambar 63). 


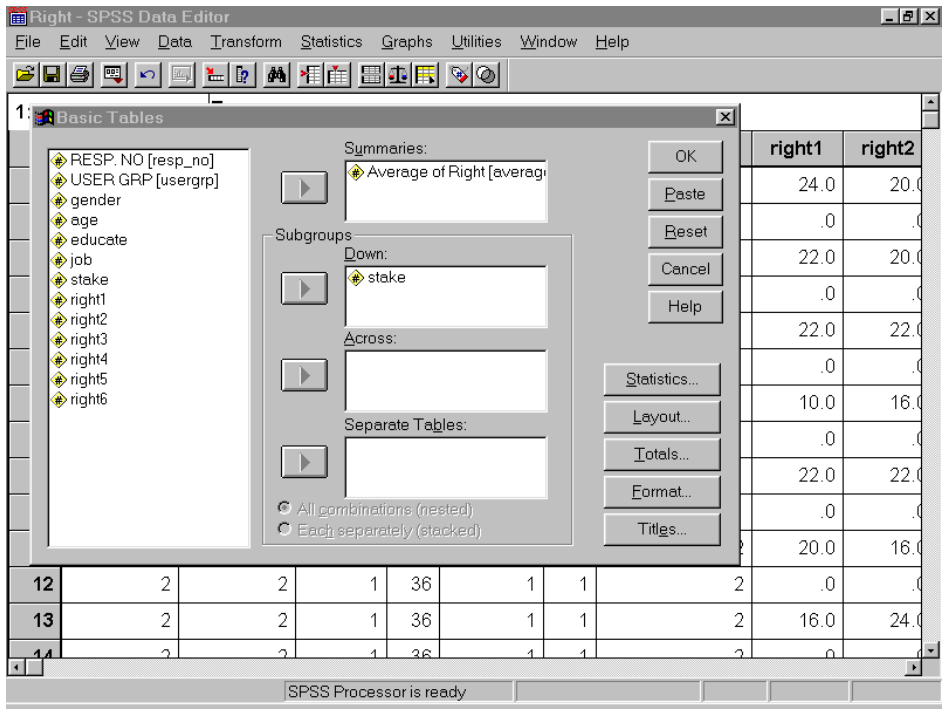

GAMBAR 63. Memilih variabel-variabel data hak mengelola untuk diringkas (Tahap 2).

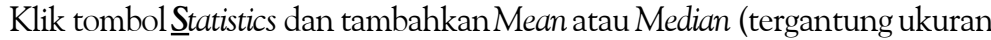
yang Anda ingin gunakan) sebagai kolom statistik.

Klik tombol OK, maka Anda akan memperoleh hasil (Gambar 64). 


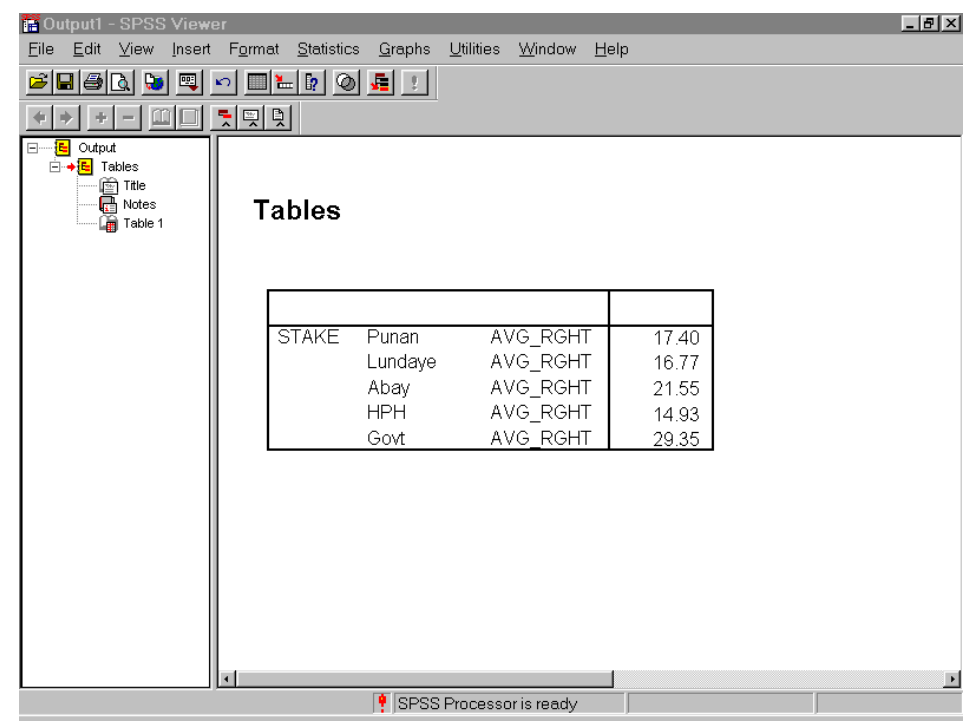

GAMBAR 64. Tabel SPSS menggambarkan distribusi hak mengelola di antara stakeholder menurut semua responden.

c. Melakukan analisis data sederhana menggunakan metode Excel

- Menghasilkan tabel untuk menggambarkan distribusi hak mengelola, menurut semua responden

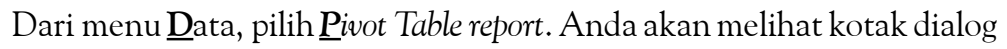
seperti yang ditunjukkan dalam Gambar 65 . 


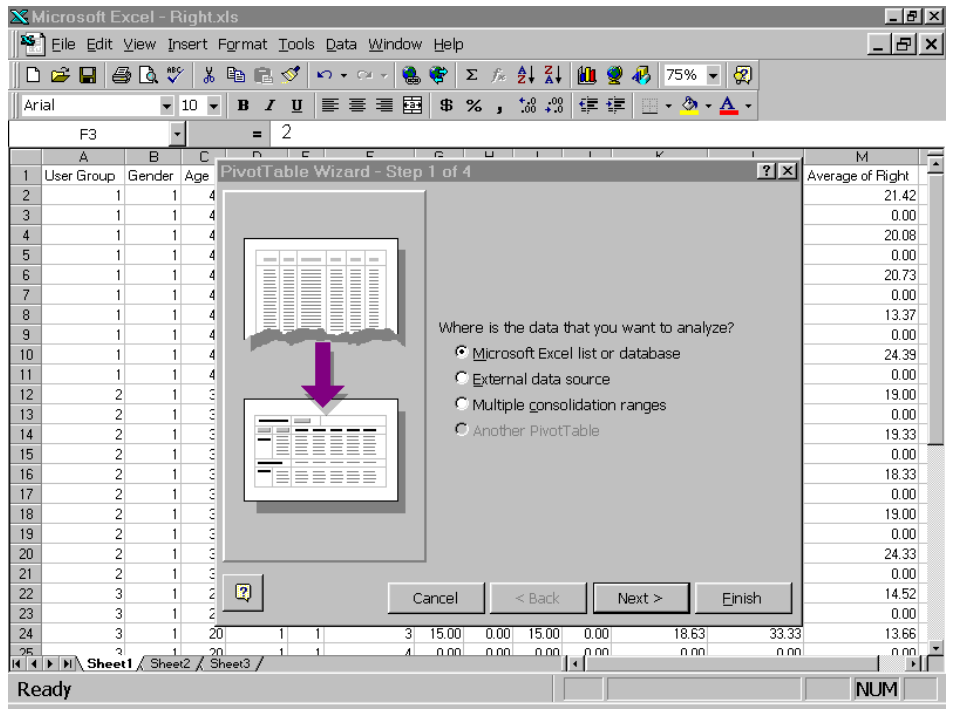

GAMBAR 65. Pola dasar tabel pivot (data hak mengelola).

Klik tombol Next dua kali, dan Anda akan melihat sebuah kotak dialog seperti yang ditunjukkan dalam Gambar 66. 


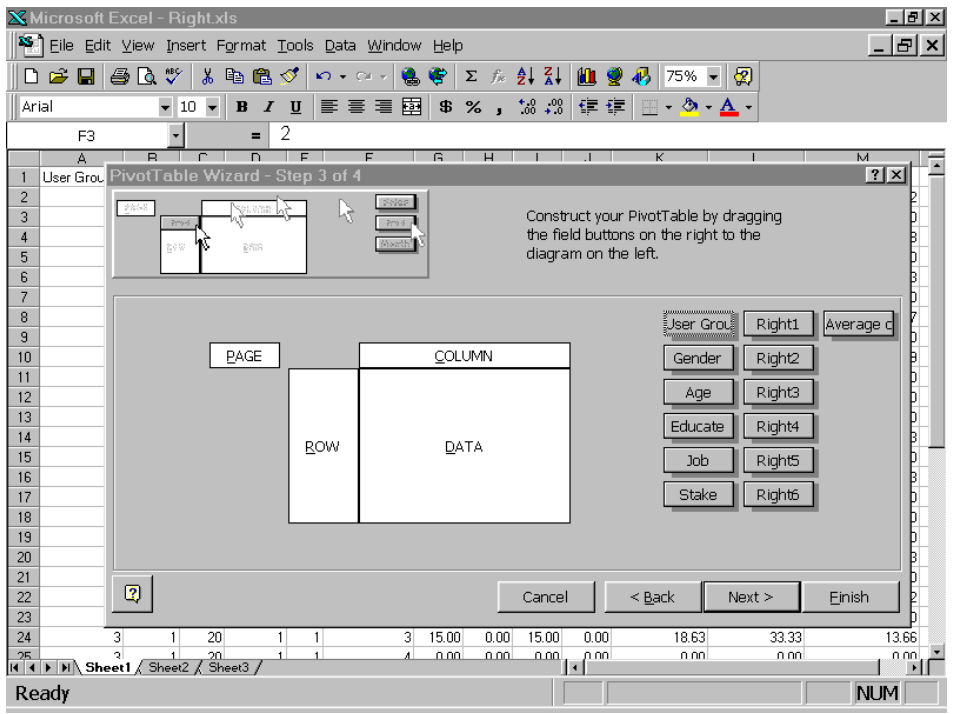

GAMBAR 66. Menyusun tabel pivot untuk analisis sederhana data hak mengelola (Tahap 1).

Tarik average of rights ke dalam ruang data dan stakeholder ke ruang baris (Gambar 67). 


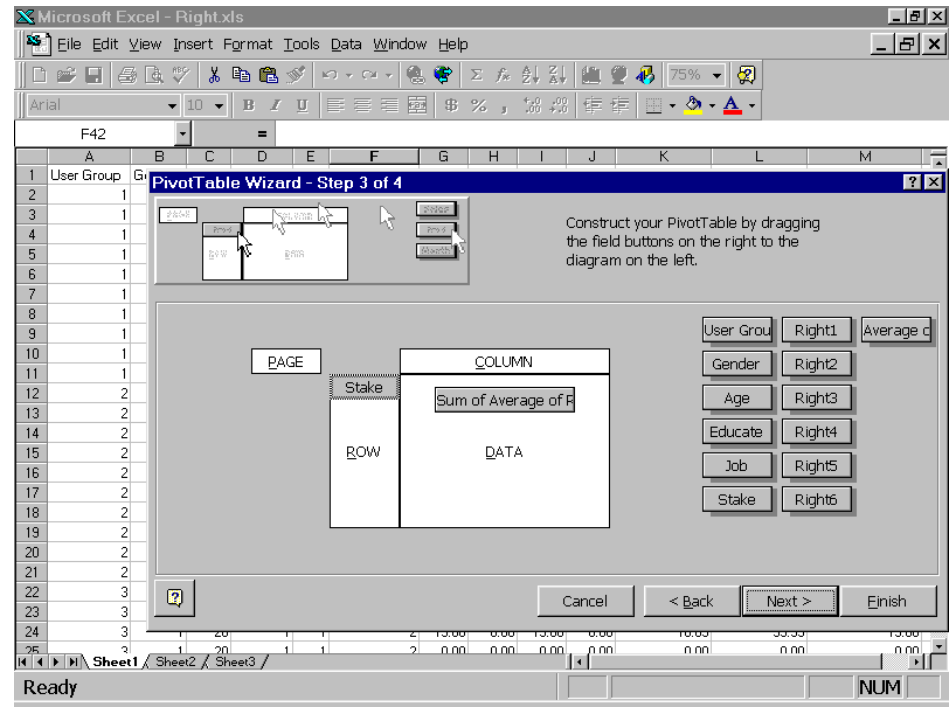

GAMBAR 67. Menyusun tabel pivot untuk analisis sederhana data hak mengelola (Tahap 2).

Jumlah (sum) merupakan statistik yang sudah diset. Statistik ini dapat Anda ubah dengan menekan tombol dua kali dan memilih statistik yang ingin Anda hitung (Gambar 68). 


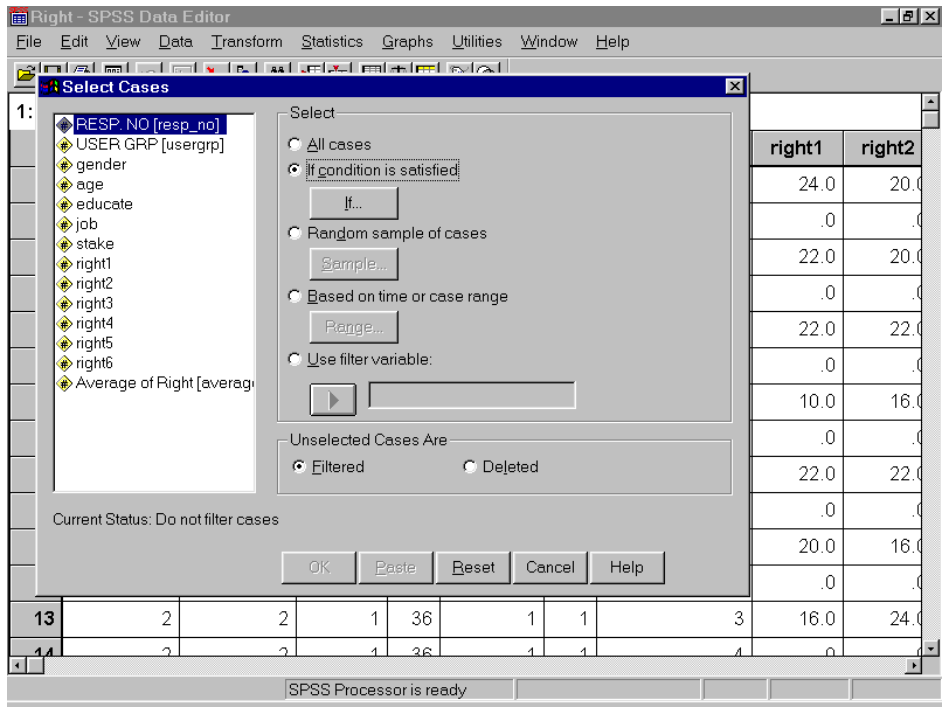

GAMBAR 68. Mengubah data statistik yang sudah diset pada data hak mengelola.

Setelah Anda menetapkan statistik yang tepat, Anda dapat mengklik tombol finish dan Anda akan memperoleh Tabel seperti yang ditunjukkan dalam Gambar 69. Jika Anda lebih menyukai jumlah digit yang lebih sedikit, Anda dapat menyesuaikan desimalnya. ${ }^{54}$

${ }^{54}$ Untuk menyesuaikan desimal, Anda dapat menggunakan menu Format pilih cells dan di bawah kategori pilih Number. Kemudian Anda dapat menyesuaikan desimal yang Anda inginkan dengan meningkatkan atau menurunkan desimal yang sudah dicantumkan (default $=2$ ). 


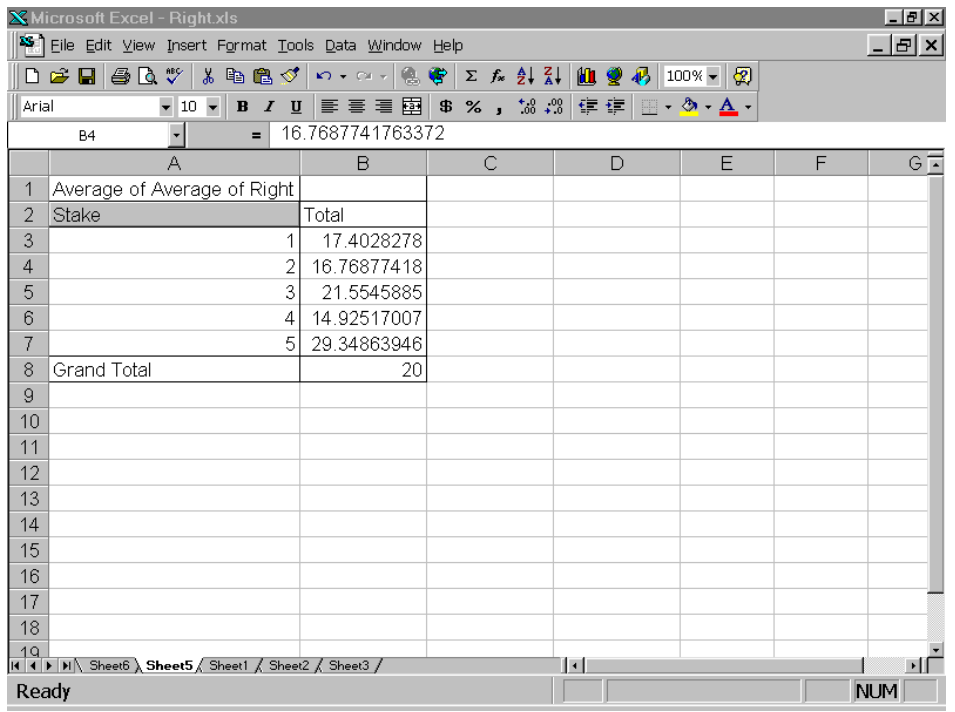

GAMBAR 69. Tabel MS Excel menggambarkan distribusi hak mengelola di antara stakeholder, menurut semua responden.

\section{d. Melakukan analisis data lanjutan dengan metode SPSS}

- Menghasilkan tabel yang menggambarkan distribusi hak mengelola, menurut subkelompok tertentu

Terkadang menarik untuk membandingkan subkelompok yang berbeda dengan masing-masing elemen demografi (etnis, jender, tingkat pendidikan, dll), berdasarkan persepsi mereka terhadap distribusi kerikil di antara para stakeholder. Untuk membandingkan persepsi subkelompok, kami perlu mengetahui gambaran distribusi hak mengelola di antara stakeholder, menurut masing-masing subkelompok. Anda dapat 
mengikuti petunjuk-petunjuk di bawah ini untuk memperoleh gambaran tersebut. Bayangkan Anda memiliki kelompok-kelompok responden dengan dua tingkat pendidikan, Sekolah Dasar dan Sekolah Menengah Pertama.

\section{Pilih dari Menu}

$\underline{\text { Data }}$

Select $\underline{\text { Cases }}$

Pilih if condition is satisfied (Gambar 70).

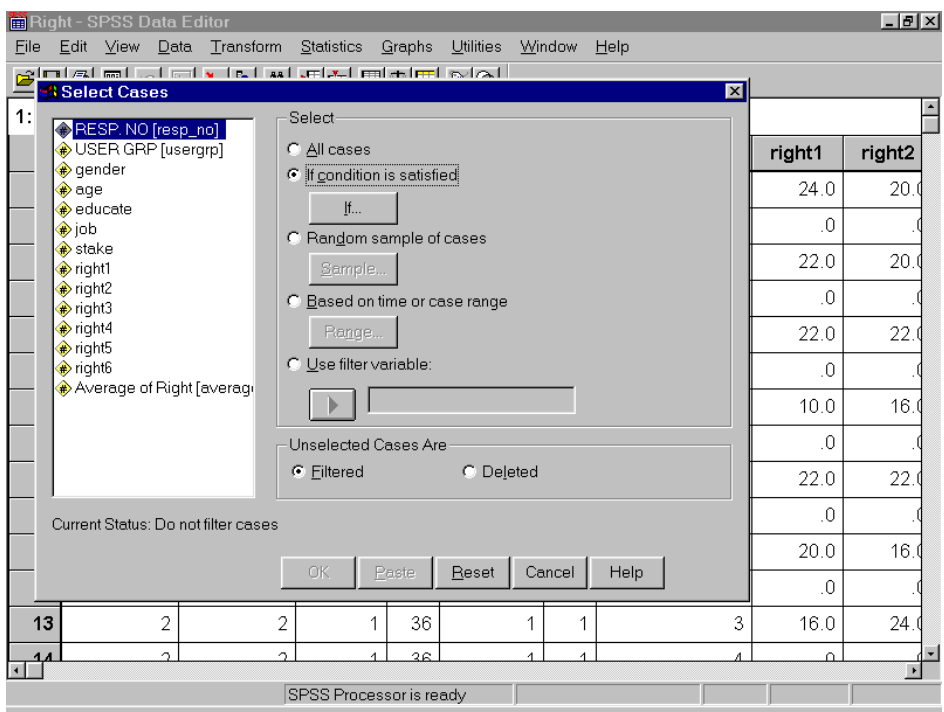

GAMBAR 70. Memilih kasus untuk subkelompok yang khusus (data hak mengelola). 
Klik tombol if.

> Lihat lembar kode Anda untuk menentukan kode bagi Sekolah Dasar dan Sekolah Menengah Pertama (misalnya, Sekolah Dasar = 1, Sekolah Menengah Pertama $=2$ ).

Ketik dalam kotak conditional educate $=1$ (Anda akan menyeleksi data dengan nilai 1 pada kolom educate).

\section{Kemudian klik Continue dan OK (Gambar 71).}

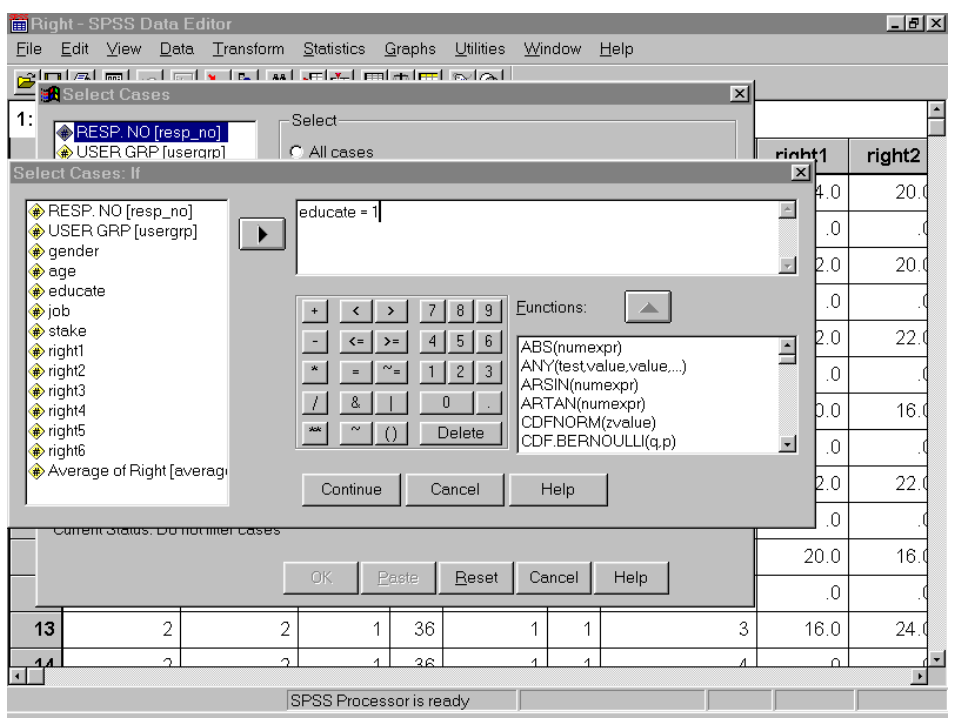

GAMBAR 71. Menyaring responden dengan tingkat pendidikan yang lebih rendah pada data hak mengelola. 
Sekarang, jika Anda perhatikan layar SPSS, mungkin ada baris-baris dengan nilai yang tidak sama dengan 1 pada kolom educate. Responden dengan tingkat pendidikan lebih tinggi dan yang tidak termasuk dalam analisis tidak diaktifkan. Status tidak aktif ini ditandai dengan sebuah garis diagonal pada nomor baris (lihat Gambar 72).

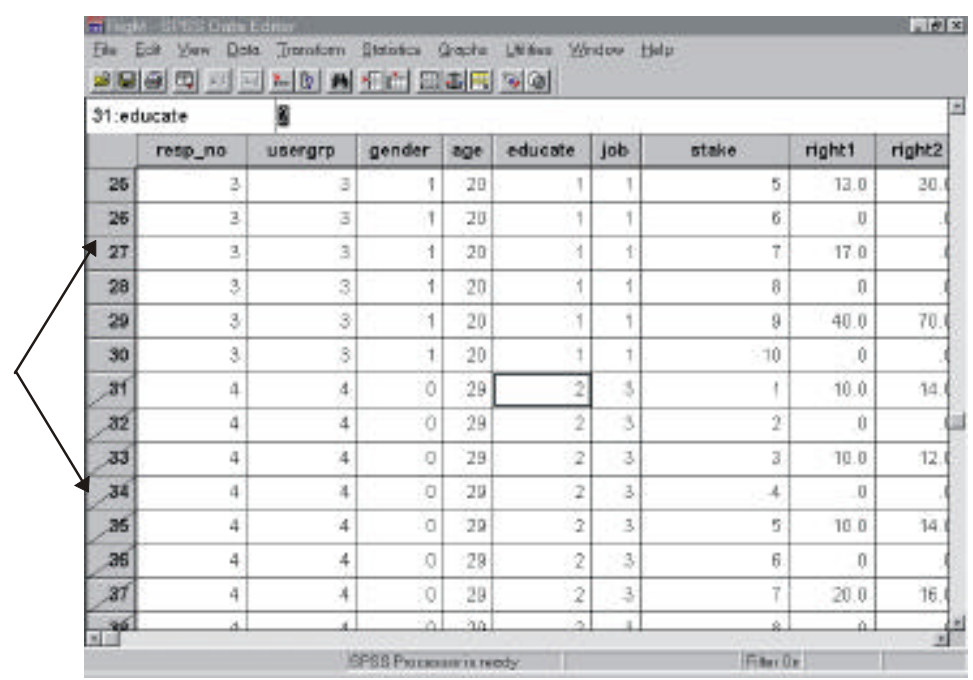

GAMBAR 72. Hasil seleksi kasus (data hak mengelola).

Lakukan langkah yang sama seperti dalam tahap 4 (Bagian b dalam bab ini), untuk memperoleh rata-rata distribusi kerikil menurut responden dengan tingkat pendidikan Sekolah Dasar (Gambar 73).

> Untuk memperoleh rata-rata distribusi kerikil menurut responden dengan tingkat pendidikan Sekolah Menengah Pertama, ubah saja the conditional expression menjadi:

educate $=2$ 
Kemudian lakukan langkah yang sama seperti dalam tahap 4 (Bagian b dalam bab ini).

> Sekarang kita dapat membandingkan perbedaan distribusi kerikil di antara dua stakeholder dengan tingkat pendidikan yang berbeda (Gambar 74).

> Jika Anda memiliki lebih dari dua kategori data demografi, Anda dapat melanjutkan langkah yang sama untuk memperoleh nilai mean/median distribusi kerikil di antara stakeholder.

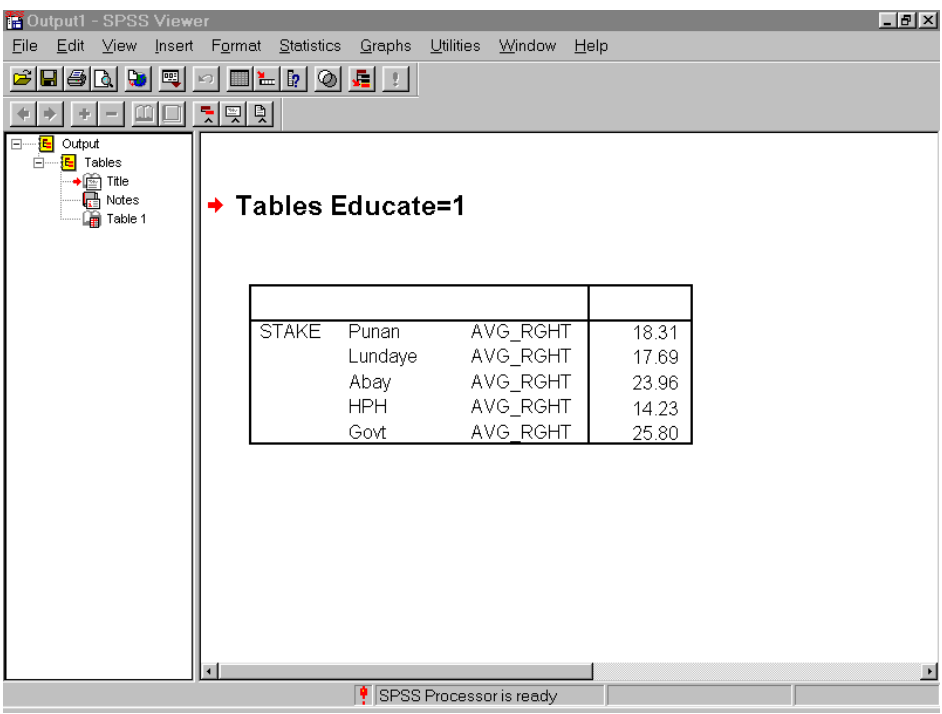

GAMBAR 73. Distribusi hak mengelola di antara stakeholder menurut responden dengan tingkat pendidikan lebih rendah. 


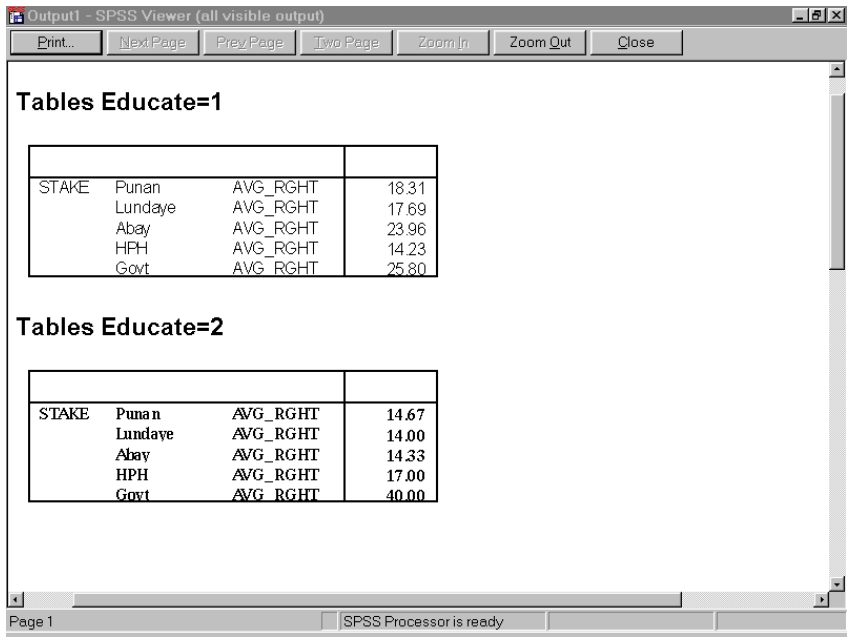

GAMBAR 74. Perbandingan distribusi hak mengelola di antara stakeholder berdasarkan tingkat pendidikan.

- Menguji kesepakatan/ketidaksepakatan di antara kelompok-kelompok yang berbeda tentang distribusi hak mengelola

Anda dapat memeriksa ada tidaknya kesepakatan di antara kelompokkelompok yang berbeda dengan masing-masing ciri demografi ${ }^{55}$ tentang besarnya hak mengelola hutan yang dimiliki masing-masing stakeholder. Anda dapat melakukan analisis untuk masing-masing stakeholder. Pertama yang harus Anda lakukan adalah menyaring data sehingga hanya baris untuk stakeholder tertentu yang aktif dan baris lainnya tidak aktif.

55 Ciri-ciri demografi di sini dapat berupa jender, tingkat pendidikan, etnis, dll. 
Dalam kasus ini kami menyaring data sehingga hanya baris Punan (Stake $=1)$ yang aktif (lihat Gambar 75). Untuk panduan rinci cara menyaring data lihat Bagian d di atas.

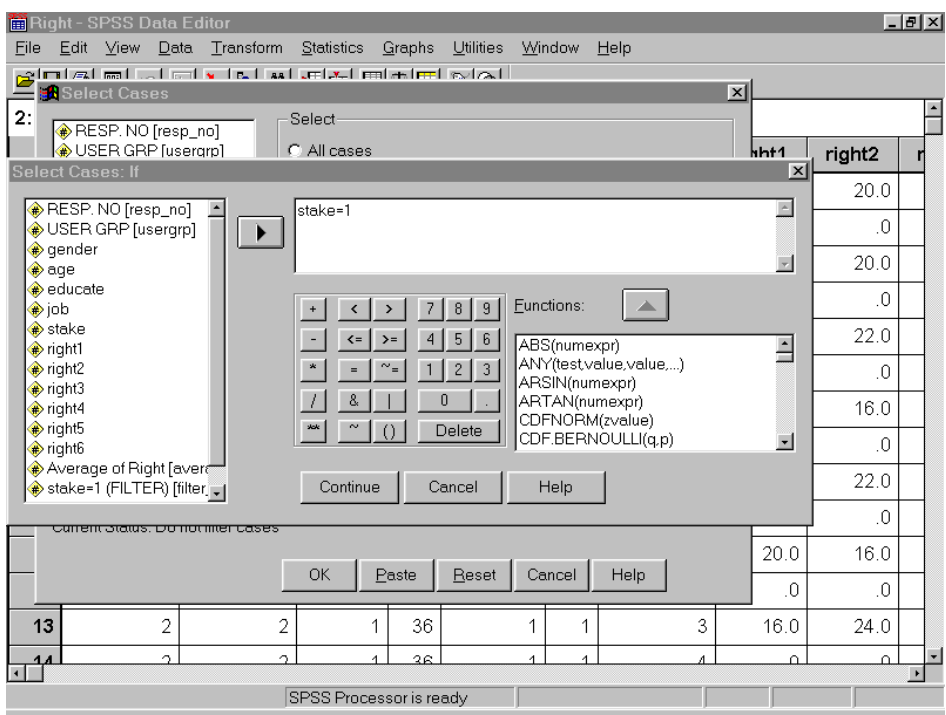

GAMBAR 75. Menyaring data untuk Punan (data hak mengelola). 
Pilih dari menu

Statistics

Nonparametric test

$\underline{2}$ independent samples atau

$\underline{\text { Kindependent samples }}{ }^{56}$

(Lihat Gambar 76)

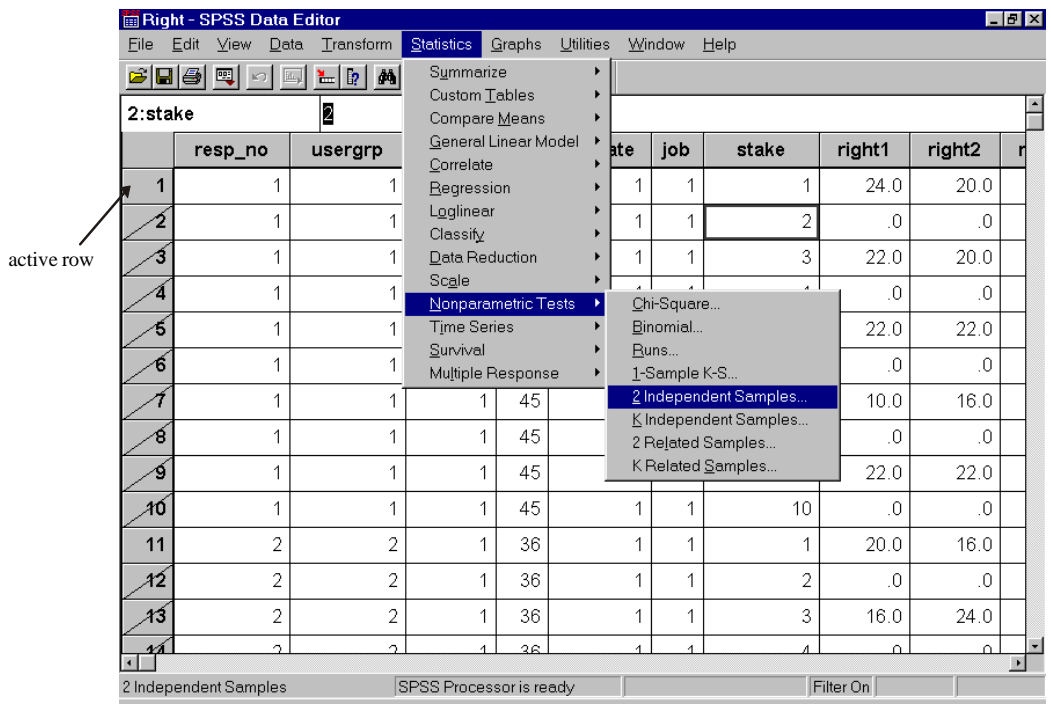

GAMBAR 76. Memilih tipe pengujian statistik untuk menguji kesepakatan data hak mengelola.

56 Jika Anda ingin menguji data hanya dengan dua kategori/dua kelompok, Anda harus memilih 2 Independent Sample dan kemudian gunakan uji Mann-Whitney. Jika Anda menggunakan lebih dari dua kategori, Anda harus memilih sampel K-independent, dan kemudian gunakan uji Kruskall-Wallis. 
Letakkan test variable ${ }^{57}$ ke dalam kotak test variable list dan kelompokkan variabel ke dalam kotak grouping variable (Gambar 77). Kemudian Anda harus menetapkan nilai minimum dan maksimum dari grouping variable seperti yang ditunjukkan dalam Gambar 78 (Anda dapat melihat arti dari masing-masing kode pada lembar kode).

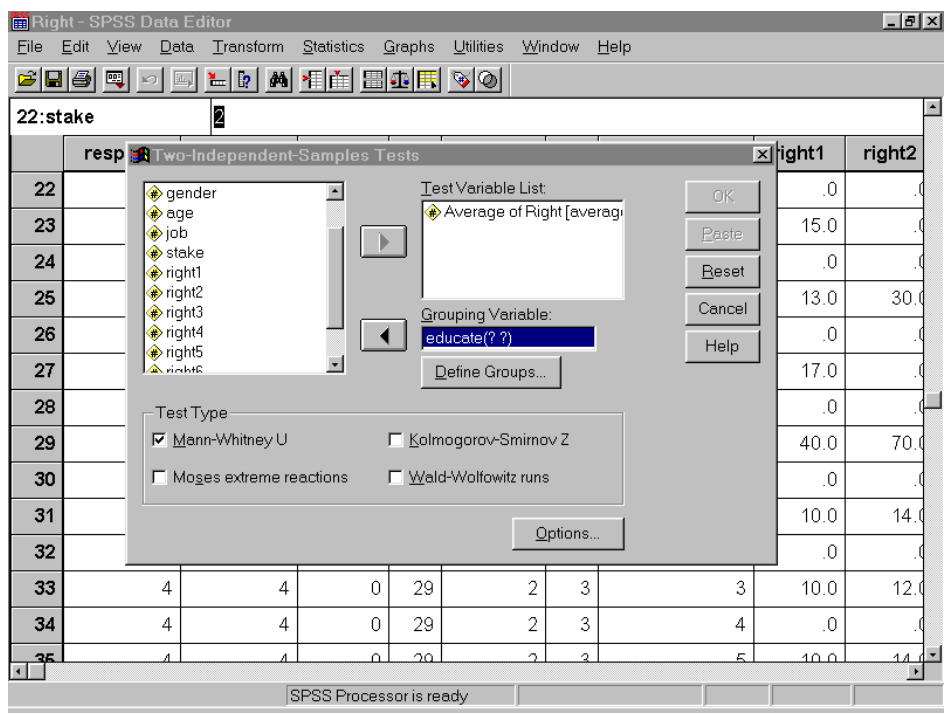

GAMBAR 77. Memilih test variable dan grouping variable (data hak mengelola).

57 Test variable harus mengandung kolom data kerikil untuk masing-masing manfaat. Grouping variable merupakan kolom yang berisi ciri demografi subkelompok yang ingin kita bandingkan. 


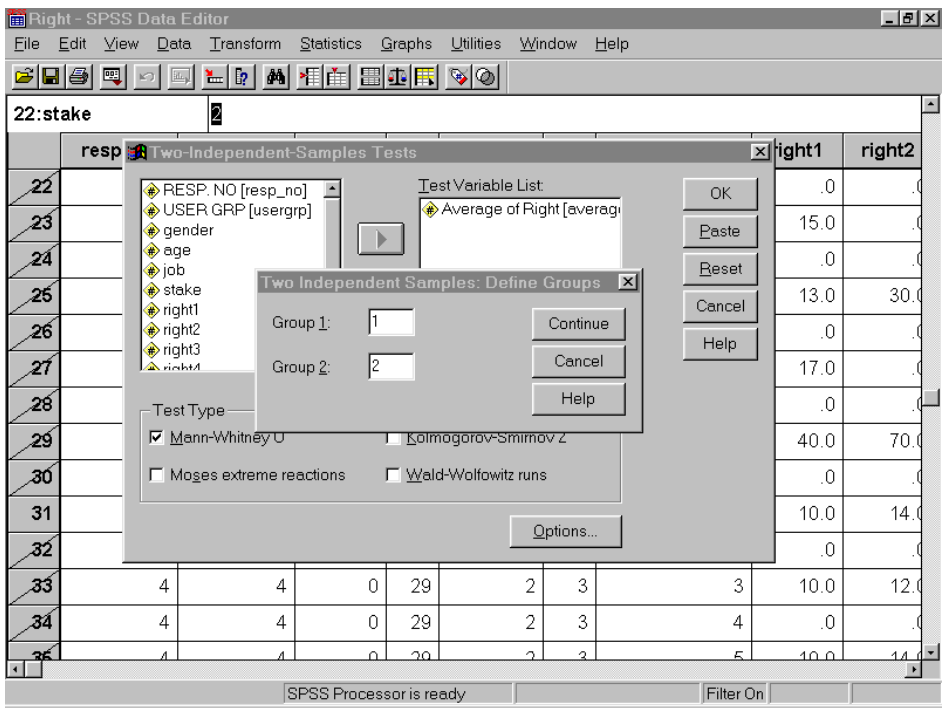

GAMBAR 78. Menentukan kisaran untuk grouping variable (data hak mengelola).

\section{Klik Continue dan kemudian OK.}

> Anda akan memperoleh hasil seperti yang ditunjukkan dalam Gambar 79.

Lihat nilai-p (ditandai oleh tanda panah). Jika nilai-p berada di bawah 0,05, kami menolak hipotesis ketiadaan ${ }^{58}$ dan berkesimpulan ada ketidaksepakatan di antara kelompok-kelompok mengenai jumlah kerikil yang dimiliki oleh stakeholder tertentu. Jika nilai-p berada di atas 0,05

${ }^{58}$ Hipotesis ketiadaan berarti: Bahwa semua subkelompok mendapatkan jumlah kerikil yang sama untuk stakeholder yang sedang diuji, dengan kata lain, semua subkelompok setuju dengan jumlah hak yang diberikan kepada stakeholder yang sedang diuji. 
kami berkesimpulan ada kesepakatan di antara kelompok-kelompok yang berbeda.

Anda dapat melakukan analisis yang sama untuk stakeholder lain, dengan mengganti data yang disaring. Misalnya jika Anda ingin menguji jumlah kerikil yang diberikan kepada Lundaye ${ }^{59}$ (Lihat pada lembar kode Anda dan berikan kode untuk Lundaye sebagai Stake $=2$ ). Kemudian ubah status seleksi dalam Gambar 18 untuk Stake $=2$ dan lakukan prosedur yang sama untuk melakukan pengujian statistik.

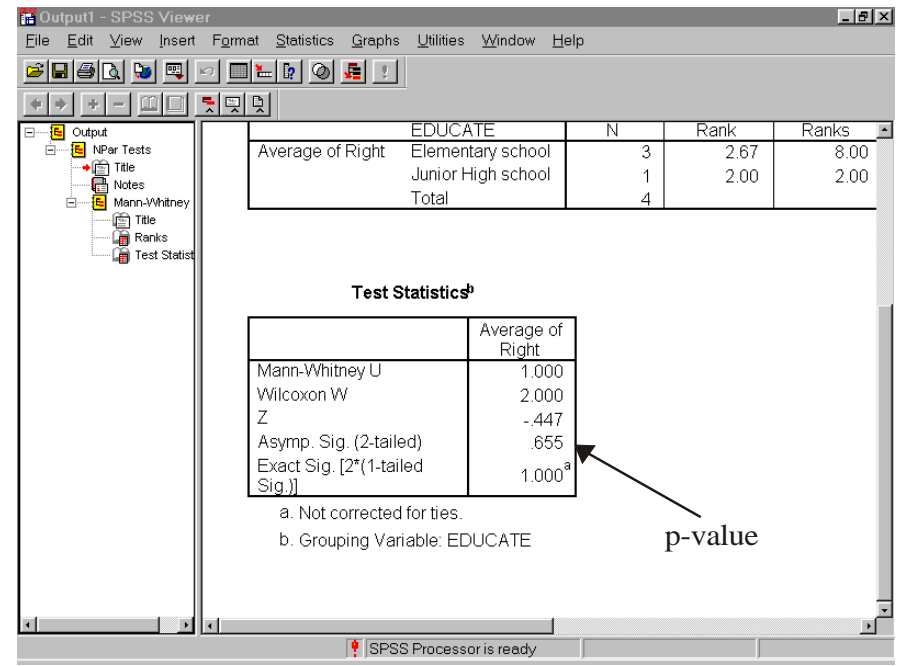

GAMBAR 79. Hasil pengujian statistik untuk Punan berdasarkan tingkat pendidikan (data hak mengelola).

59 Lundaye merupakan salah satu kelompok etnis mayoritas di Paking, Bulungan di mana pengujian lapangan kami lakukan. 


\section{e. Melakukan analisis data lanjutan menggunakan metode Excel}

- Menghasilkan tabel untuk menggambarkan distribusi kerikil, menurut subkelompok tertentu

Anda dapat menggunakan prosedur yang sama untuk membuat tabel distribusi kerikil menurut semua responden. Perbedaannya hanya ketika Anda menyusun tabel pivot. Selain menarik semua manfaat ke ruang data dan stakeholder ke ruang baris, Anda juga harus menarik kolom di mana subkelompok ${ }^{60}$ tertentu berada ke dalam ruang kolom (Gambar 80). Dalam contoh ini kami menggunakan tingkat pendidikan sebagai contoh.

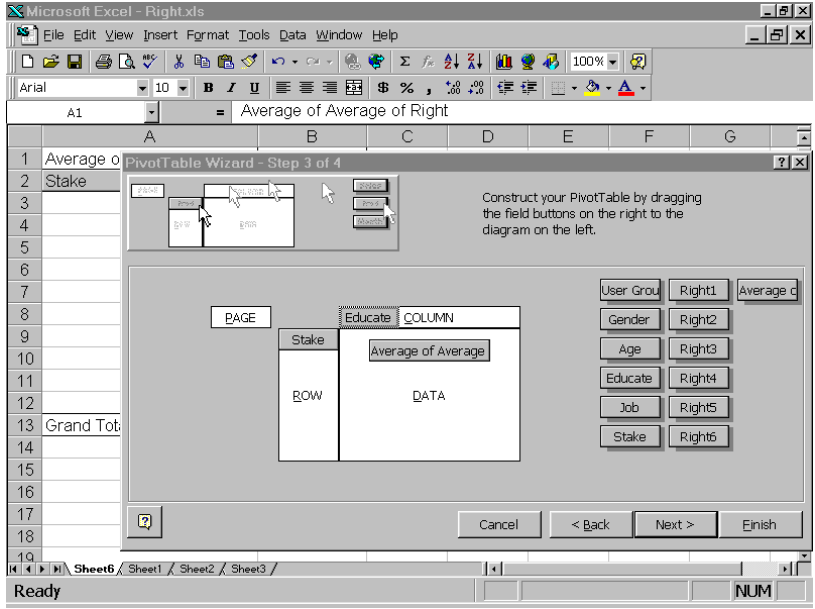

GAMBAR 80. Menyusun tabel pivot untuk analisis lanjutan data hak mengelola.

${ }^{60}$ Subkelompok di sini dapat berupa jender, tingkat pendidikan, umur, etnis, dll. 
Klik tombol finish, maka Anda akan memperoleh hasilnya (Gambar 81). Ada dua subtabel untuk masing-masing tingkat pendidikan (dalam contoh ini, seperti sebelumnya, tingkat pendidikan 1 artinya Sekolah Dasar, sementara tingkat pendidikan 2 artinya Sekolah Menengah Pertama).

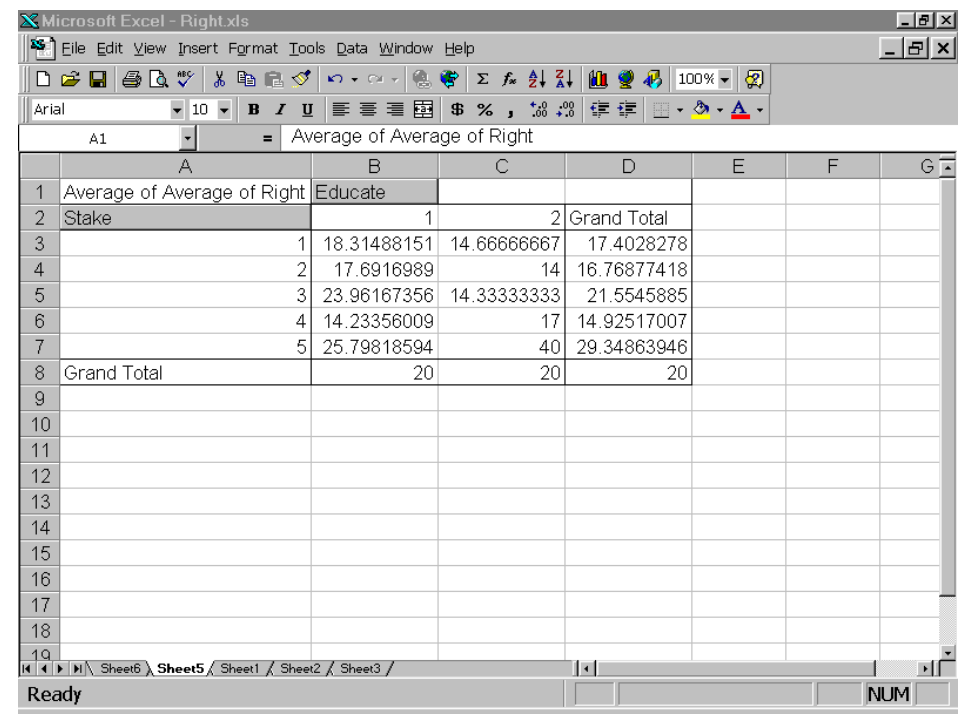

GAMBAR 81. Tabel MS Excel menggambarkan perbandingan distribusi hak mengelola berdasarkan tingkat pendidikan. 


\section{KESIMPULAN}

Panduan ini telah dirancang untuk digunakan dengan perangkat $K \& I$ lainnya, terutama PPD dan PPPD. Panduan Cara Pemberian Skor dan Analisis untuk Menilai Kesejahteraan Manusia mencakup tiga topik utama: panduan cara pemberian skor, panduan pembuatan lembar isian induk K\&I dan panduan analisis kuantitatif. Yang pertama (I) memberikan kepada para pengguna beberapa perbandingan kondisi global yang terkait dengan skor yang diyakini masuk akal oleh para penulis dan didasarkan dari percobaan di lapangan yang penting dalam pengujian K\&I. Tujuan panduan ini adalah untuk membantu para pengguna dalam membuat penilaian terhadap kondisi yang mereka temui di lapangan, berkaitan dengan kesejahteraan manusia. Yang kedua (II) dirancang untuk para pengguna yang relatif kurang akrab dengan penggunaan lembar kerja komputer, dan menjelaskan proses pembuatan dan penggunaan lembar kerja, maupun memberikan suatu metode pemberian skor yang diusulkan secara keseluruhan dan lebih terinci. Yang ketiga (III) dan yang terpanjang memberikan perincian hal-hal penting tentang cara menganalisis hasil dari beberapa metode kuantitatif yang diuraikan dalam PPD dan PPPD. Panduan ini dapat digunakan sebagai dokumen acuan, di mana para pengguna akan secara langsung berhubungan dengan bagian yang paling relevan dengan kebutuhan utamanya.

Dalam panduan ini, kami telah mencoba untuk menyediakan bantuan dan panduan dalam melakukan penilaian, pemberian skor dan analisis data dari prosedur-prosedur penilaian yang sulit. Walaupun kami menganggap prosedur-prosedur ini banyak membantu, kami mengakui tugas-tugas penilaian yang diperlukan tetap berat. Penilaian kesejahteraan manusia bukan tugas yang ringan. 
Kami tetap yakin akan hasil penilaian yang baik dari penilai yang berpengalaman dan bersimpati untuk terus mencari cara yang kreatif melalui prosedur-prosedur yang disarankan dalam panduan ini. Suatu metode penilaian yang baik tetap memerlukan pikiran yang aktif dari penilainya. Kami belum pernah menemukan cara penilaian pengelolaan hutan lestari, termasuk kesejahteraan manusia, yang dapat kami ikuti prosedur-prosedurnya secara membuta dan mendapatkan kesimpulan yang masuk akal. Kami mengakhiri panduan ini dengan mengajak para pengguna untuk tetap terus mengembangkan pemikiran mereka sambil memeriksa kondisi-kondisi penduduk di dalam dan sekitar hutan yang sedang mereka nilai. 


\section{E - DAFTAR PUSTAKA}

Colfer, C.J.P., M.A. Brocklesby, C. Diaw, P. Etuge, M. Günter, E. Harwell, C. McDougall, N.M. Porro, R. Porro, R. Prabhu, A. Salim, M.A. Sardjono, B. Tchikangwa, A.M. Tiani, R.L. Wadley, J. Woelfel dan E. Wollenberg. 1999. The BAG (Basic assessment guide for human well-being). The Criteria \& Indicators Toolbox Series No. 5. CIFOR, Bogor, Indonesia.

Colfer, C.J.P., M.A. Brocklesby, C. Diaw, P. Etuge, M. Günter, E. Harwell, C. McDougall, N.M. Porro, R. Porro, R. Prabhu, A. Salim, M.A. Sardjono, B. Tchikangwa, A.M. Tiani, R.L. Wadley, J. Woelfel dan E. Wollenberg. 1999.The Grab Bag: Supplementary Methods for Assessing Human Well Being. Criteria \& Indicators Toolbox Series No. 6. CIFOR, Bogor, Indonesia.

Draper, N. dan Smith, H. 1981. Applied regression analysis. Wiley, New York.

Makridakis, S., Wheelwright, S.C. dan McGee, V.E. 1983. Forecasting: Methods and applications. Wiley, New York.

Sardjono, M.A., E. Rositah, A. Wijaya, dan E.M. Angie. 1997. A test of social science assessment methods concerning indicators and criteria for sustainable forest management in East Kalimantan. CIFOR Report. CIFOR, Bogor, Indonesia.

SPSS for Windows, Rel. 8.0.0. 1997. SPSS Inc., Chicago.

Tchikangwa, N.B., dengan S. Sikoua, M. Metomo dan M.F. Adjudo. 1998. Test des méthodes en sciences sociales de vérification des critères et indicateurs d aménagement durable des forêts: Périphérie est de la Réserve du Dja (SudCameroun). CIFOR Report. CFOR, Bogor, Indonesia.

Woelfel, J.K. 1998. User s Guide CatPac II version 2.0. Rah Press, Amherst, NY. 


\section{LAMPIRAN A: MEMERIKSA PERKIRAAN ANALISIS REGRESI}

\section{HOMOGENITAS VARIANSI RESIDUAL (HOMOSCEDASTICITY)}

Homoscedasticity artinya bahwa variansi residual konstan untuk nilai apa pun dari variabel bebas (X). Distribusi residual yang berbentuk kerucut dibandingkan dengan nilai yang telah ditetapkan akan memberi kesan bahwa variansi residual tidak konstan (lihat Gambar 82a dan 82b). Suatu model yang memenuhi syarat asumsi akan memiliki variansi residual yang konstan, seperti ditunjukkan dalam Gambar 82c.

Jika residual menunjukkan pola a atau b, Anda dapat menggunakan regresi weighted linear (Draper dan Smith 1981).

Untuk pembahasan lebih lanjut bagaimana mengatasi masalah ini, silakan berkonsultasi dengan statistikawan. 
(a)

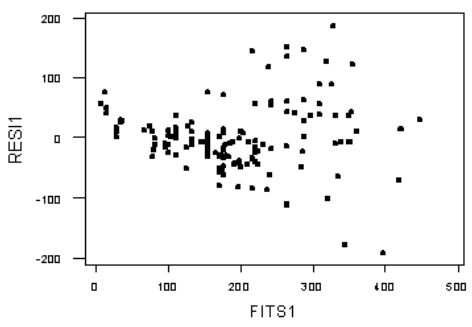

(c)

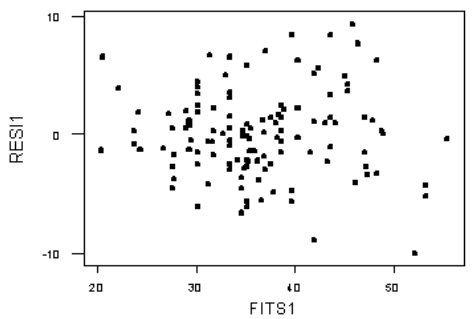

(b)

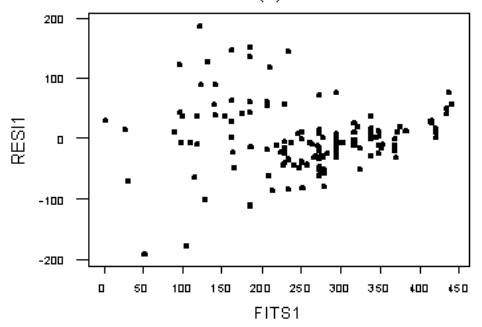

GAMBAR 82. Beberapa pola variansi residual.

\section{KENORMALAN RESIDUAL}

Analisis regresi menunjukkan bahwa residual-residual model menunjukkan distribusi normal, ${ }^{61}$ dengan nilai mean dan kesatuan standar deviasi nol. Ada banyak pengujian untuk memeriksa asumsi kenormalan, termasuk Uji Kolmogorov-Smirnov dan Uji Shapiro-Wilk. Kedua cara pengujian ini mudah dilakukan dengan menggunakan Minitab. Namun, kita juga dapat memeriksa perkiraan secara cepat menggunakan plot Q-Q normal.

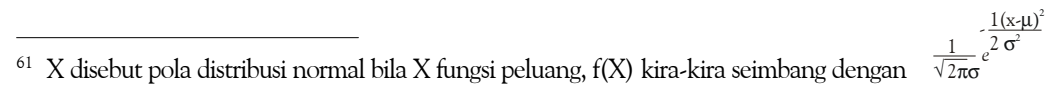
di mana $\mu$ dan $\sigma^{2}$, berturut-turut adalah mean dan variansi variabel. 
Jika Anda menjalankan analisis regresi dengan menggunakan Excel, ingatlah bahwa Anda telah mengklik pilihan Normal Probability Plot. Pilihan ini akan menampilkan plot kuantil-kuantil normal (Q-Q), seperti dalam Gambar 83.

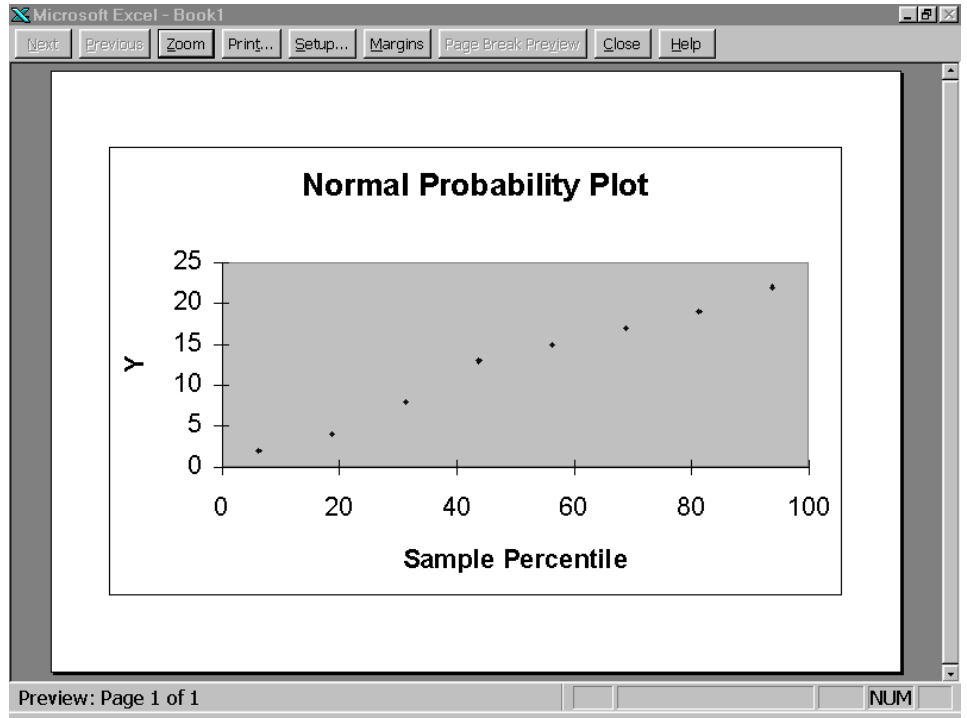

GAMBAR 83. Normal Probability Plot dari residual.

Jika pola residual berupa garis lurus, dapat disimpulkan bahwa distribusi residual sesuai dengan pola distribusi normal. Semakin jauh distribusi residual dari pola garis lurus, maka distribusinya semakin tidak mengikuti pola distribusi normal. Jika hal ini terjadi, pengujian yang lebih rinci seperti yang dianjurkan di atas harus dilakukan. Silakan konsultasikan dengan statistikawan mengenai cara melakukan dan mengambil kesimpulan dari pengujian. 


\section{RESIDUAL YANG TIDAK BERKORELASI}

Dalam analisis regresi, kami menganggap bahwa kesalahan pengamatan adalah tidak berkorelasi. Tentu saja ada kesalahan dalam kasus-kasus tertentu di mana residualnya berkorelasi (Draper dan Smith 1981). Fenomena seperti ini sering ditemui ketika kita berhadapan dengan data time series. Pola umum yang paling sering kami temukan adalah jika residual ke-i (dalam urutan waktu) pengamatan memiliki korelasi yang linier dengan residual untuk pengamatan ke-(i-1). Gambar 84a dan 84b menunjukkan dua plot yang mengungkapkan adanya hubungan fungsional antara residual-residual. Gambar 84a menunjukkan kecenderungan positif melalui pemisahan residual satu tahap; sementara Gambar 84b menunjukkan kecenderungan negatif.

Korelasi antara pengamatan ke-i dan ke-(i-1) disebut korelasi seri lag-1. Untuk melihat keberadaan korelasi seri dari lag yang lebih besar, Anda dapat membuat plot residual dalam dua tahap, tiga tahap, yang berbeda dsb. Jika residual saling berkorelasi, beberapa metode dapat digunakan, termasuk regresi autoregressive.

(a)

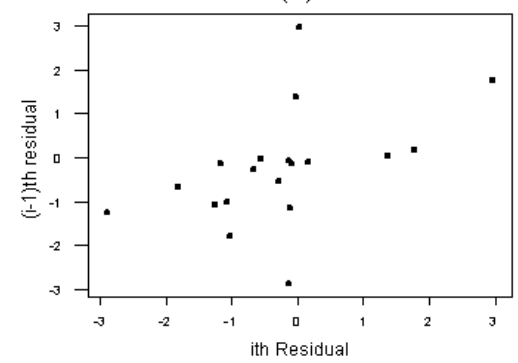

(b)

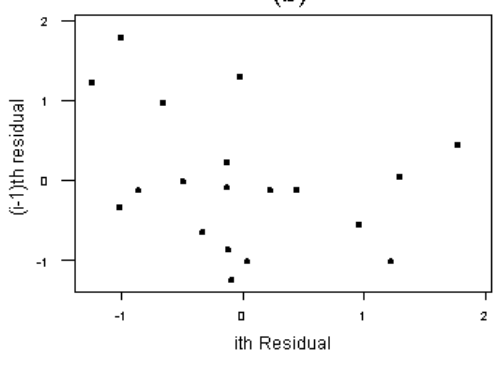

GAMBAR 84. Plot menunjukkan residual yang saling berkorelasi. 


\section{Sistem CGIAR}

The Consultative Group on International Agricultural Research (CGIAR) adalah suatu asosiasi informal yang terdiri dari 41 organisasi donor dari sektor publik dan swasta yang mendukung jaringan enam belas lembaga penelitian internasional di bidang pertanian, di mana CIFOR merupakan anggota terbaru. Asosiasi ini didirikan pada tahun 1971. Pusat-pusat CGIAR merupakan bagian sistem penelitian global di bidang pertanian yang berusaha menerapkan kemampuan ilmiah internasional untuk menyelesaikan masalah-masalah yang dihadapi olehmasyarakatmiskin di dunia.

\section{CIFOR}

CIFOR adalah bagian sistem CGIAR dengan tugas khusus untuk menanggapi kepedulian global tentang dampak kerusakan dan kehilangan hutan terhadap kondisi sosial, lingkungan dan ekonomi masyarakat. CIFOR beroperasi melalui berbagai kemitraan yang sangat terdesentralisasi dengan lembaga-lembaga dan/atau individu terpenting di seluruh negara industri dan negara yang sedang berkembang. Sifat dan jangka waktu kemitraan ini ditentukan oleh masalahmasalah penelitian khusus yang dihadapi. Agenda penelitian ini terus-menerus dikaji dan selalu mengalami perubahan ketika para mitra menemukan berbagai masalah dan peluang baru. 
Panduan Cara Pemberian Skor dan Analisis untuk Menilai Kesejahteraan Manusia dirancang untuk melengkapi Panduan Penilaian Dasar (PPD) dan Panduan Pendamping Penilaian Dasar (PPPD). Perangkat ini menyajikan metode cara pemberian skor yang dapat digunakan bersama dua panduan tersebut, sampai membuat keputusan tentang kriteria dan indikator khusus dalam konteks hutan atau masyarakat tertentu. Setelah pembahasan tentang pemberian skor, bagian selanjutnya membahas cara melakukan analisis. Cara analisis ini dimulai dengan sangat sederhana, memandu pengguna melakukan tahap-tahap dalam membuat lembar isian, dan kemudian dilanjutkan dengan analisis statistik yang lebih kompleks yang mungkin lebih diperlukan untuk situasi tertentu. Tim yang berbeda memiliki kepentingan berbeda dalam hal kecanggihan analisis statistik dan kuantitatif yang mereka perlukan. Perangkat ini mempertimbangkan dan menanggapi berbagai kepentingan yang berbeda ini. 